\title{
Best Marketing
}

Practices in Peru

A selection of the 2015 AND A Awards winners

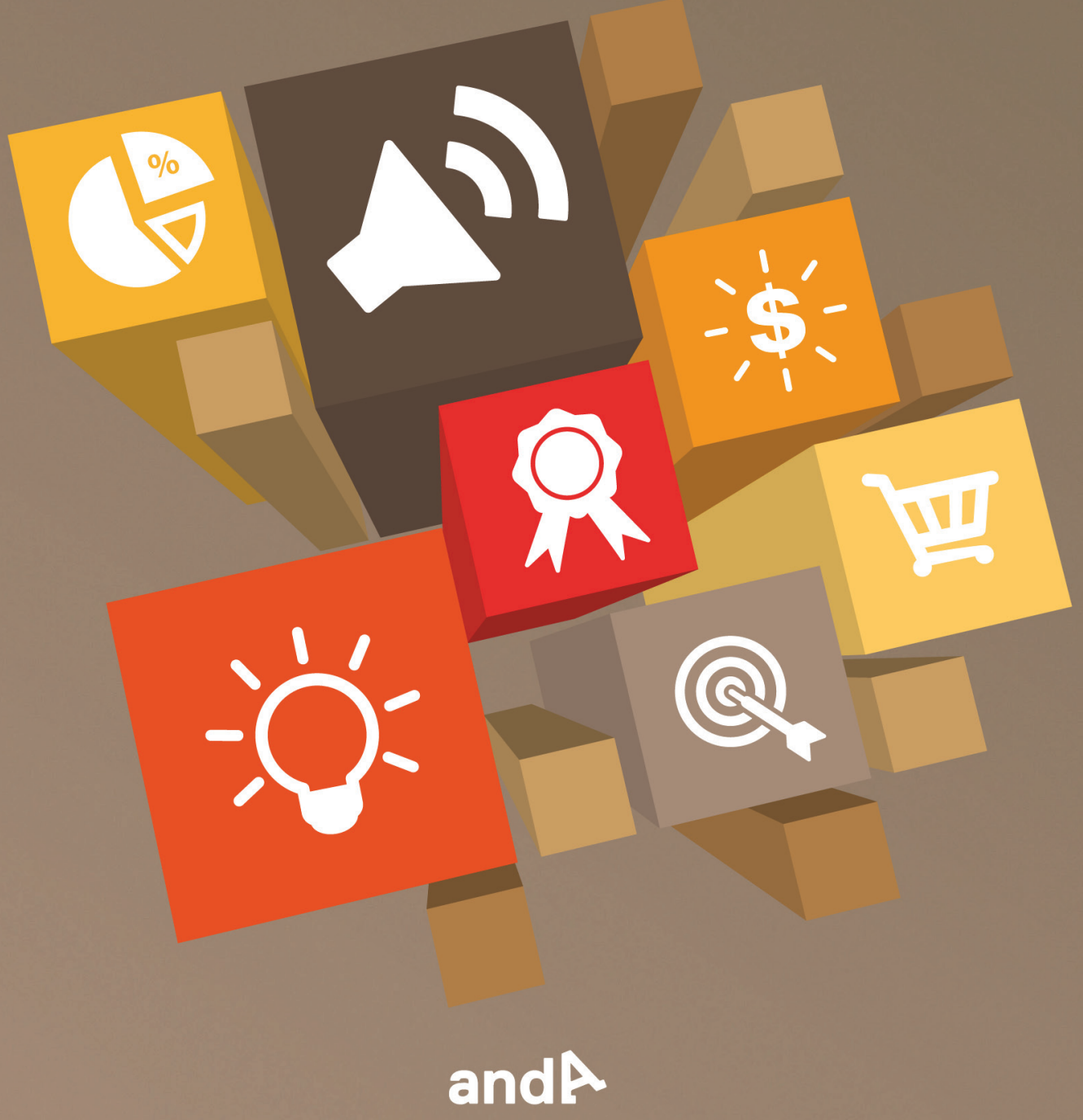




\section{Best Marketing \\ Practices in Peru}

Lima, October 2015

Universidad Peruana de Ciencias Aplicadas 
(C) Universidad Peruana de Ciencias Aplicadas (UPC)

First edition: October 2015

Printed in Peru

Writing: Javier Montoya / Magda Simons

Copy editing: Gabriela Vargas Philippón

Cover design: Diana Patrón Miñán / Christian Castañeda

Layout design: Diana Patrón Miñán

Editor del proyecto editorial

Universidad Peruana de Ciencias Aplicadas S.A.C.

Av. Alonso de Molina 1611, Lima 33 (Peru)

Telephone: 313-3333

www.upc.edu.pe

First edition: October 2015

Print run: 1,200 copies

This book was printed in October 2015 at the printing house of

Metrocolor S. A. located in Los Gorriones 350, La Campiña, Chorrillos. Lima-Peru

\section{(C) Universidad Peruana de Ciencias Aplicadas (UPC) Information Center}

Best Marketing Practices in Peru. A selection of the 2015 ANDA Award winners

Lima: Universidad Peruana de Ciencias Aplicadas (UPC), 2015

ISBN (spanish printed edition): 978-612-318-037-9

ISBN (spanish e-pub edition): 978-612-318-039-3

ISBN (spanish PDF edition): 978-612-318-038-6

ISBN (english PDF edition): 978-612-318-049-2

Marketing, marketing strategies, commercial companies, creativity,

advertising campaigns, advertising awards, case studies, Peru.

658.80985

All rights reserved. This publication cannot be reproduced, in whole or in part, or recorded in or transmitted by any information recovery system in any form or by any means, such as mechanical, photochemical, electronic, magnetic, electrical optical, by photocopy or any other means, without the prior written permission of the publisher.

The contents of this book are the responsibility of the author and they do not necessarily reflect the opinion of the editors. 


\section{Table of Contents}

Table of Contents $\quad 5$

$\begin{array}{ll}\text { Presentation } & 7\end{array}$

$\begin{array}{lr}\text { Presentation } & 9\end{array}$

Cálidda and its Commitment to Society's Welfare 13

Purina Dog Chow's Perrotón, Pets Are Part of the Family 25

$\begin{array}{ll}\text { BCP: Unstoppable Evolution in Mobile Banking } & 37\end{array}$

Pilsen Callao Evokes the Excitement of Friendship from Yesterday, Today and Always 51

Field and Its 150 Years of Memories, Longings and Feelings with All Peruvians 65

Marketing 3.0 in search of the consumer and society's well-being 81

$\begin{array}{ll}\text { A Customer-Focused Strategy in a Highly-Concentrated Market } & 97\end{array}$

UPC University Press Recent Publications $\quad 111$ 



\section{Presentation}

On behalf of the National Association of Advertisers (Asociación Nacional de Anunciantes - ANDA), we congratulate and express our gratitude to Universidad Peruana de Ciencias Aplicadas (UPC) for gathering, for the first time, a special selection of the 2015 ANDA Award winners in this publication. It is an effort that we celebrate thanks to the momentum it provides to academic dissemination of representative business cases of good practices in our industry.

The ANDA Award, in force since 2003, is aimed at recognizing and disclosing the most outstanding actions in the commercial communication industry, through the invitation to and organization of a public competition that rewards and highlights the most significant and transcendental contributions to the industry, presenting them as development excellence models. The companies or institutions that meet the general competition requirements can participate. A select panel of distinguished professionals from the industry evaluate the cases and choose the winners in each category to ensure the impartiality and objectivity of the process.

The awards ceremony takes place at a gala that brings together the main figures of the industry, making this a very representative event in our industry.

At ANDA, we know this contribution is important for the country. That's why we insist on promoting the best practices of commercial communication through the public recognition to the best contributions of each discipline within our industry. The award categories provide a space to all commercial communication activities so as to allow all industry disciplines to participate, regardless of the company's size, and thus enrich this great event.

We feel proud that UPC appreciates this ANDA initiative and invests effort to bring it to this enduring publication. We are confident that this work will continue year after year in each award celebration.

We express our gratitude to the entire UPC staff involved in making this publication possible, and to the companies that shared their valuable experiences, which we expect will be useful and inspiring for readers.

Rodolfo León

CEO, National Association of Advertisers (ANDA) 



\section{Presentation}

In the Administration and Marketing study program of Universidad Peruana de Ciencias Aplicadas (UPC), we are continuously improving and we want to provide an added value to all the activities we carry out.

One aspect of our mission, as part of the School of Business and of the University itself, is to manage to turn our students into upstanding professionals, who are innovative leaders with critical thinking, goal and team-work oriented.

Therefore, when the National Association of Advertisers (ANDA) suggested that we published a selection of the 2015 ANDA Award winning campaigns; we understood that it would be a good opportunity to publish a book of real success stories in Peru. The intention of this book is to become a new tool that students can use in their analysis and critical thinking development, competencies that we must promote and are now demanded by the labor market.

Our intention is to share every year the new marketing strategy cases submitted to the ANDA Awards. This way, students, professionals and entrepreneurs will be able to see, in a tangible manner, how to achieve effectiveness in the activities and excellent business results from innovative proposals, which are mainly developed in marketing.

During the selection process of the marketing strategies included in this book, we considered those whose comprehensive campaign consisted of implementing strategies based on research and insights and with very challenging goals. This selection criterion was adopted because we seek to give examples of the management and implementation of the above concepts and other basic concepts for marketing students and professionals.

Furthermore, it should be noted that the annual publication of ANDA winners' selection is complemented with another initiative of the UPC Administration and Marketing program that became more powerful in 2014: the Annual UPC Marketing Conference (CAMUPC). Its academic value has substantially contributed to the education of our students and in the updating of all professionals that are part of the program. Our conference brings together world-level speakers and executives of the leading 
companies in the country that deliver valuable conferences for three days. In addition, the conferences are complemented with the presence of international speakers.

We hope that this first book will be useful for those interested in innovating, creating and communicating so as to achieve specific and transcendental goals.

\section{James Leigh}

Administration and Marketing Program Director Universidad Peruana de Ciencias Aplicadas 


\section{«Pon de tu parte» Campaign}

\section{Company:}

Cálidda - Gas Natural de Perú

\section{Category:}

Best advertiser in a social responsibility campaign 


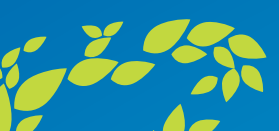

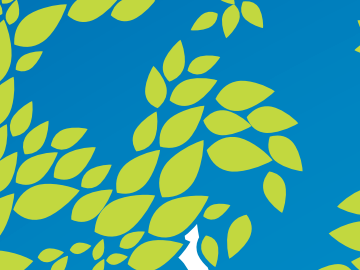

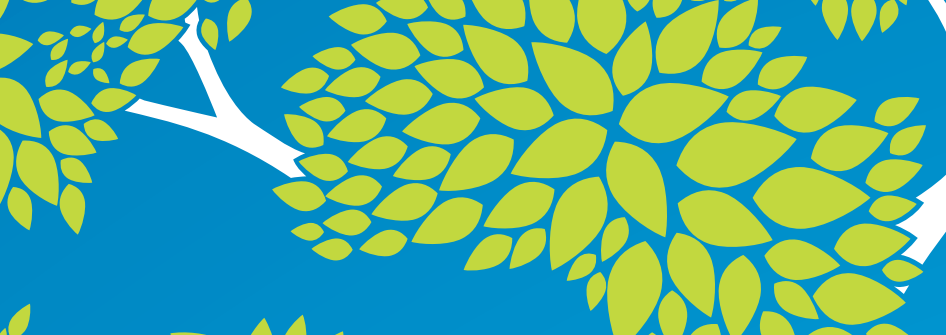

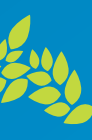
0.2. * Y N 103350 - 


\section{Cálidda and its Commitment to Society's Welfare}

Within the context of the COP 20 in Peru, Cálidda became a strategic ally to the Ministry of the Environment (MINAM, in Spanish) in supporting the environmental initiative «Pon de tu parte» (Do Your Part), whose purpose was to raise awareness regarding the relationship between current practices and climate change, through the subscription of climate commitments. In eight months of work, Cálidda assumed the role of coordinator between the State, the private industry sector, non-governmental organizations and society. The result: more than 300,000 commitments.

\section{BACKGROUND}

Currently, Peru generates 24,000 tons of solid waste (SW) per week, which equals filling up four national stadiums ${ }^{1}$. As for Lima, it generates more than 8,202 tons of waste per day, a figure that could double in 20 years ${ }^{2}$.

Given this reality and in line with the corporate responsibility and environmental protection policy, Cálidda plays an active role in generating environmental awareness in the community in each of its processes and in its interaction with its stakeholders.

In 2014, Lima was the seat of the Twentieth Conference of the Parties for Climate Change, COP 20. This conference was considered the key link for the signing of a new binding agreement to replace the Kyoto Protocol at COP 21. The event brought together presidents, ministers and representatives of the civilian and the private sector of 195

1 Cf. Life Out Of Plastic (LOOP).

2 Cf. Environmental Assessment and Control Agency (Organismo de Evaluación y Fiscalización Ambiental OEFA) (2014). In: El Comercio, November 12. 
countries. The COP 20 allowed to present the current environmental situation and the creation of a community committed to the environment and climate change. It also left a legacy for Peru, giving way to a great social environmental mobilization.

\section{The Proposal}

Voluntarily and in coordination with the Ministry of the Environment, Cálidda designed an action plan which included, as main strategy, seeking an alliance with other institutions to engage them with the program and promote their active participation. The purpose of this teamwork vision was to increase the scope of the activities proposed in Cálidda's plan. Then organizations such as Peru 2021, Megaplaza, Cineplanet, Mistura, Avina, IPES, SPDA, McCann Erickson, and IBM were added in order to raise awareness in the largest number of Lima citizens as possible in relation to the importance of protecting the environment.

The purpose of the campaign was to obtain 300,000 commitments towards climate and raise environmental awareness in the community. To do this, Cálidda developed its activities between May and December 2014, when the COP 20 was held. The TV commercial was included in the programming and on social networks four weeks prior to COP 20 .

\section{THE IMPLEMENTATION}

The website www.pondetuparte.com was published and, as part of this relationship strategy, the following actions were taken:

1. Participation in the Private Sector Forum. This forum, organized by the Secretary General of the United Nations in New York, was attended by Ollanta Humala, President of Peru; Manuel Pulgar-Vidal, Environment Minister; and Adolfo Heeren, General Manager of Cálidda, representing the Peruvian private sector. In this event, a proposal was presented to take the «Do Your Part» Campaign to all countries in order to make it part of each one of the next COP.

2. Environmental pack development. A free campaign geared toward companies was organized; its purpose was to disseminate information through printed material and awareness talks promoting the adoption of environmental commitments. With 
the support of Peru 20213 , different institutions were reached, which adopted the initiative and shared it in their offices for a period of two weeks. Peru 2021 is a Peruvian nonprofit civil association, founded in 1994, whose initial goal was to take responsibility for articulating a shared national vision towards 2021, the bicentennial of Peru's independence. Since 1996, it committed to disseminate and promote Social Responsibility (SR) as a business management method, aimed at promoting large, medium and small businesses to become agents of change to reach the country's sustainable development.

3. Participation in Mistura. Cálidda, hand in hand with the social enterprise LOOP4 ${ }^{4}$ led the Fair Sustainability Program, through which more than 300 volunteers educated the attendees on waste segregation in some 70 recycling bin points. LED screens were also used to broadcast eco-tips for visitors. This audiovisual material informed about the risks of the excessive use of plastic and disposable items, encouraged the use of carpooling, and the reuse of packaging. Additionally, Cálidda used this platform with more than 450,000 attendees to implement an area dedicated to spreading the «Do Your Part» Campaign, with examples and samples of recycled objects (like bags). With this activity, over 17,000 commitments were made, thanks to the daily and permanent support of young university students recruited by IPES 5 in a collaborative effort with MINAM, who voluntarily participated by encouraging the adoption of commitments and taking selfies announcing their obligation.

3 Cf. Perú 2021 (2015) Portal de Responsabilidad Social del Perú (http://www.peru2021.org) (accessed: September 18)

4 Cf. Life Out Of Plastic (LOOP) (2015) Official website of this social business oriented to environmental or social issues (www.lifeoutofplastic.com) (accessed: August 15)

5 Cf. Promoción del Desarrollo Sostenible (IPES) (2015) Official IPES website (www.ipes.org) (accessed: September 18) 


\section{«Pon de tu parte» Campaign website}

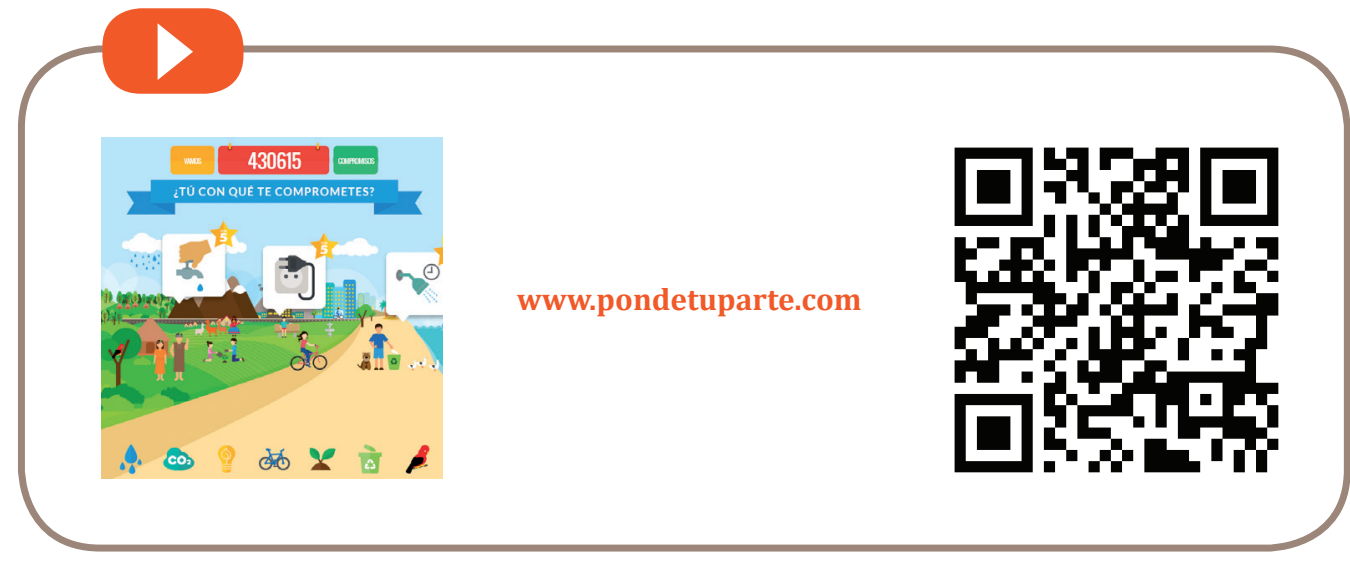

In addition to this core strategy, Cálidda developed the following actions:

\section{Mass Dissemination Strategy}

In order to achieve a greater impact on raising awareness on environmental protection, Cálidda considered developing a TV ad important.

The aim of this TV commercial was to communicate the problem in an attractive and simple way, focusing on everyday actions that the audience could feel familiar with, thus becoming aware of the consequences of their habits in the environment.

To achieve these communication challenges, Cálidda secured an alliance with the McCann Erickson advertising agency, which understood the nature of the message. It was important for the message to be emotional with a reflection ingredient; consequently, it was decided to turn around the cliché phrase that questions what kind of planet we are passing on to our children, so a new phrase that would become a wake-up call to grownups was created: «Think about what kind of children you are passing on to the planet.» For this, the ad showed common habits of adults that harm the planet, of which they are generally not aware, and focused on how these are seen and imitated by children. To make the commercial more catchy and generate empathy with all ages, a jingle with the phrase «I'd like to be just like my mom/dad» was used, reinforcing the fact that children take their elders as a reference even for the smallest actions. 
The advertising plan and schedule included presence in open signal national TV stations, such as Frecuencia Latina, America Televisión, Panamericana Televisión and ATV. It aired for four weeks, reaching an estimated 9,648 views.

\section{«Think about What Kind of Children You Are Passing on to the Planet» Tv Commercial}

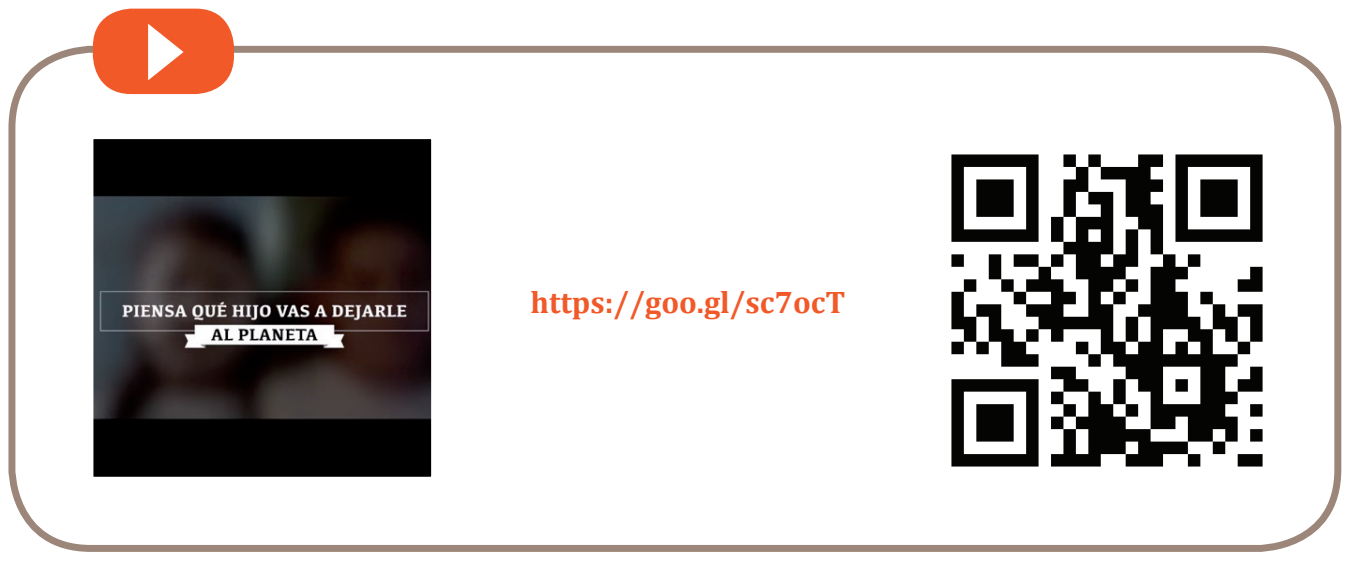

\section{BTL Strategy}

In order to have direct contact with the people so as to promote the adoption of commitments in favor of the environment, it was decided to prioritize the messages, focusing them on the sound waste administration and management, specifically plastic. The basis for this approach was the 2011 statement made by the United Nations Environment Programme (UNEP), where plastic contamination was recognized as one of the emerging worldwide problems due to the impact of plastic in the marine ecosystem and the potential risks to human health.

The main promotional activities of this strategy were:

1. Children workshops at Megaplaza. Over 8,000 visitors participated in the educational recycling workshops, where kids created musical instruments made out of recycled material and plant pots made out of plastic bottles. Megaplaza passersby also enjoyed the environmental troupe that went through the mall facilities with characters dressed in costumes made of recycled material, attracting more audience to the activity. Megaplaza granted that space for free for an eight-week period. 
2. Family workshops in the «Manos a la Olla» cooking contest. This contest, organized by Cálidda, was aimed at the leaders of community kitchens benefited for free with natural gas and received more than 4,500 visitors. The 2014 edition took place in the district of Villa El Salvador. There, recycling workshops were held with used oil and ornaments made out of plastic bottles.

3. School activations. Priority was given to those schools located in the outskirts of Lima, bringing recreational and educational activities to promote environmental care. About 8,000 children participated in the awareness activities, getting environmental advice to be applied at home. Their commitments were collected by the young volunteers.

4. Outreach to Cálidda customers. The company used its customer communication channels-utility bills, newsletters and TV screens at service desks, among others - to expand the dissemination outreach of the campaign's message. The messages focused on the care of natural resources as well as their proper use.

\section{Image 1. Communication through Bills}
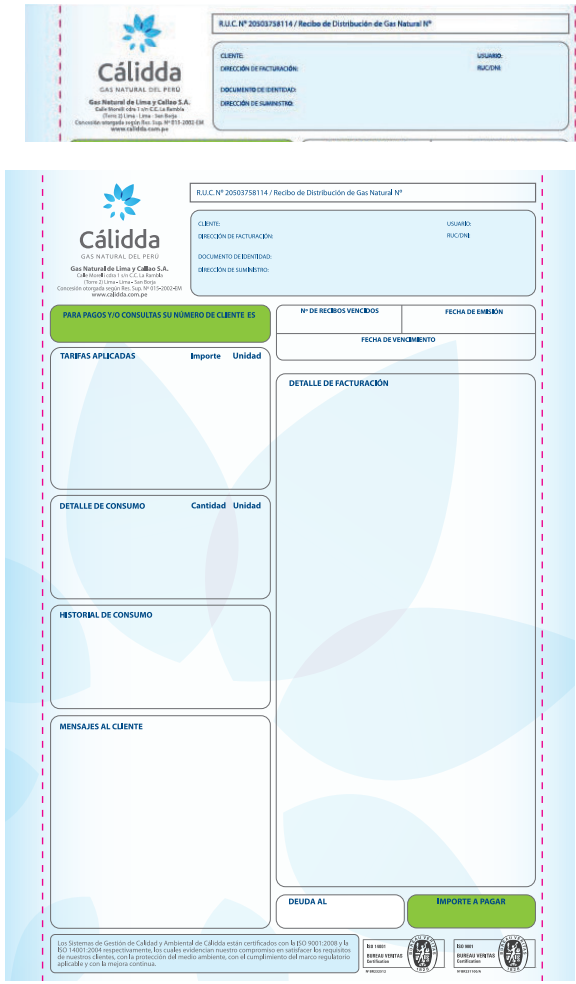
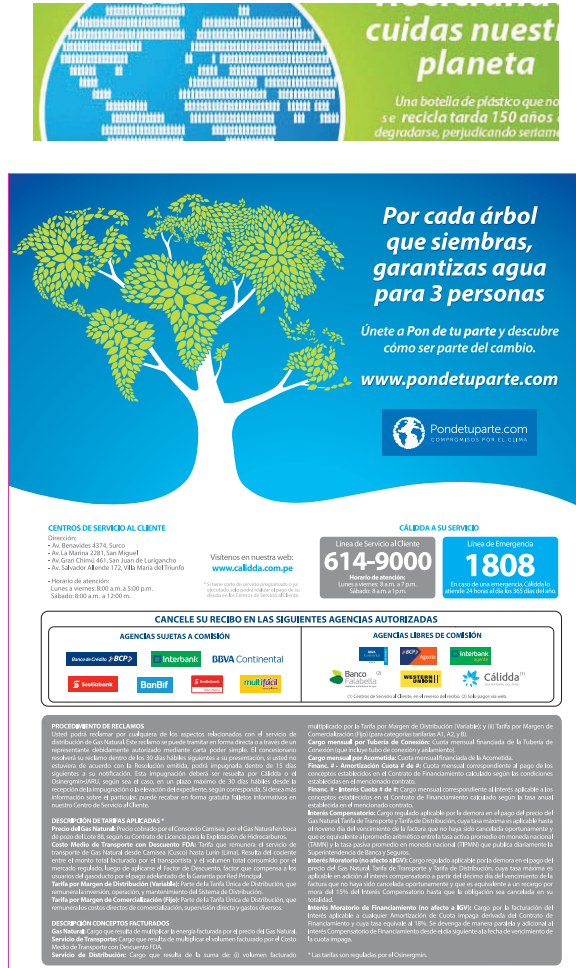
5. Outreach to Cálidda workers. A number of recycling workshops, a plastic-bottle collection campaign for the development of new products, and talks about climate change by institutions specialized in environmental issues were carried out internally. These talks were aimed at the entire staff, with the purpose of turning workers into spokespersons of the activities, among others.

6. Outreach to Cálidda suppliers. Environmental talks were held with the contractors who perform gas installation and networking services. Their involvement in this activity was considered relevant since they are in contact with the end customer. They received the environmental pack as well as a talk given by the allies of the Ministry of the Environment: Avina and IPES.

7. Outreach at Cálidda community kitchens. Cálidda's Social Responsibility department, through its Miska Wasi program, has direct contact with the ladies who lead these institutions. Therefore, part of the strategy was to take advantage of the talks and include solid waste management and recycling as topics in them. Videos of the initiative were used, in which Gastón Acurio encourages cooks to be responsible with this management and with a sustainable and responsible consumption.

\section{RESULTS}

The aim of the campaign was to obtain 330,000 commitments during the COP 20. This goal was exceeded as 429,105 commitments ${ }^{6}$ were obtained. But, also, other success indicators were identified:

The Mistura Sustainability Program was positive, recycling a total of 458,000 pounds $208,163 \mathrm{~kg}$ of materials such as plastic, cardboard, aluminum and glass. This program was chosen as one of the three most important actions by Somos magazine, in their centerfold story about Mistura7.

As for the levels of external and internal participation, the campaign was initially adopted by Cálidda workers, who made a commitment to the environment. Through talks and workshops, the workers got to know the initiative. Subsequently, they volunteered in the dissemination activities within Mistura and the «Manos a la Olla» event at the community kitchens. They actively collaborated with obtaining commitments within each activity.

6 See www.pondetuparte.com

7 Article published September 13, 2014. 
In addition, the participating suppliers and companies contributed for free not only with their own experience but also by investing resources for the attainment of the campaign objectives.

As for continuity, the initiative «Do Your Part» set the goal to stay in force in the following COPs. In Peru, there is a continuity plan managed by the Ministry of the Environment (MINAM), which seeks to continue with this outreach work.

In that sense, Cálidda has set up a work plan within its social responsibility activities that will continue supporting the initiative, both from their own activities and in those where it works together with and supporting the MINAM.

It is also worth reviewing how this campaign promoted social integration and inclusion. The meeting of people, institutions, the State and private business working toward a common goal is an unprecedented model in the country that cancels differences in social status, points of view, commercial interests and that has proven to be successful in «Do Your Part.» Participants worked for free to strengthen this campaign with the intention of meeting the goals set and changing a reality in Peru: bad practices that hurt the environment. The meetings were made up of this interdisciplinary group representing each player, enriching the development of the planned activities with their contributions and points of view.

Finally, it can be concluded that this campaign has shown that businesses growth can go hand in hand with sustainability. The success of this marketing strategy lies in a model of shared work, based on synergies with key stakeholders from all sectors to achieve high-impact products, creativity, and quality, without demanding a high budget. This is how value was given to the program and how the goals were met. Nowadays, it is really important to be aware of the world's sustainability, of everything that can be done to be part of and commit to everything related to climate change through our own habits. With this campaign, Cálidda has shown that it is possible. 


\section{Opinion}

Very often, business professionals, especially in the area of trade, make an effort to grow sales, develop marketing channels, generate demand through Trade Marketing and optimize costs and expenses to have, at the end of the day, the highest net income in our P\&L. However, what would happen with all that effort if the business were not sustainable? The Cálidda case is a clear example of how business sustainability is a strategic priority for every investor and business, and not only that, but that it adds innovation to maximize the success chances and amplify the scope with remarkable efficiency in resource utilization.

Frank Cruz

Retail Management Professor at UPC 



\section{Purina Dog Chow's «Mejores en familia» Perrotón}

Company:

Nestlé Perú S. A.

Agency:

Joe Quispe

Categories:

Digital Media-Products

Non-traditional Communication 


\section{UN GRAN EOUIPO \\ - Mejores en Familia $\longrightarrow$

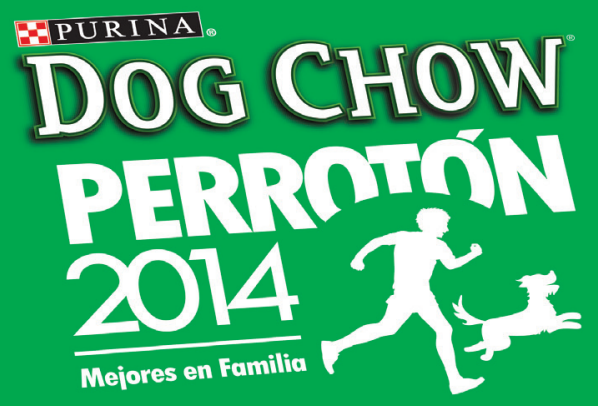

PARTICIPA CON UN EMPAQUE VACIO DE DOG CHOW

$$
\begin{aligned}
& 28 \text { SEPTIEMBRE } \\
& \text { PENTAGONITO SAN BORJA }
\end{aligned}
$$

PARA MAYOR INFORMACLÓN INGRESA A:
WWW.DOGECHOW PRRTOTON.COM.PE como nos preparamos!

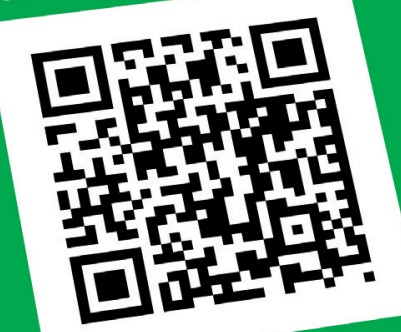

(2) Dogdowiper f dogdowp

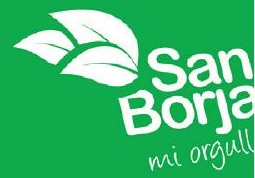

H.T. N $^{\circ}: 20^{1}$ Lima desde el septiembre dar stock de 28 ds carrera 28 


\section{Purina Dog Chow's Perrotón, Pets Are Part of the Family}

«Purina Dog Chow's Perrotón 2014» started as a dog and owner race (a dog-a thon) and today it has become a festival which translates into a brand experience that attracts more and more participants every year. Leveraging on the powerful insight: «a family is a better family with a dog, a dog is better dog because it has a family,» this idea has already been implemented in other Latin American countries. In 2014, the strategy took a new turn because it focused not only on pets, but also on the bond with their families. Consequently, the «Dog Chow's 'Mejores en familia' (Family Makes it Better) Perrotón'» was created.

\section{BACKGROUND}

Through the years, Purina Dog Chow's brand has been generating value in Peru and it has positioned itself as its segment's category voice, creating messages of responsible pet ownership and a tradition such as the Perrotón.

The brand has the most active social network digital community in its category; however, it wasn't using this brand asset to generate more activity and engagement inside its community. Besides, no other current platforms or social networks had been created to support its interaction.

The Perrotón had been positioned only as a marathon or race, excluding those families or dog owners who did not necessarily practice these kind of activities with their pets. From that, the great concept of «Mejores en familia» (Family Makes it Better) was developed within the proposal. 
The brand's main digital objective is to improve the engagement level together with interaction because this indicator makes it possible to verify whether the content being delivered is relevant and whether it truly connects with the target, since this category is extremely emotional, additionally to offering functional nutritional benefits inside the food.

\section{The Proposal And its Implementation}

The Purina Dog Chow's «Mejores en familia» Perrotón teaser and registration campaign began on September 1, 2014, and the event's main date was set for September 28.

Based on the business brief and the competitive bidding among many agencies, Joe Quispe and his team understood the business need, and the planning and production were set in motion three months in advance of the main date for Dog Chow's Perrotón 2014.

As planned, the announcement would be made one month in advance so as to attract one thousand participants who had to register to participate in the race or take part in the festival.

\section{Phase 1: Teaser Campaign}

This phase was launched on the brand's social networks such as Facebook and Instagram. Messages related to sports and family were posted, providing tips on how to exercise together with your pet, as well as advice for taking care of their footpads, hydration and heart rate.

The followers' enthusiasm was evident as they shared posts and requested that the Perrotón 2014's date be revealed. 


\section{Image 1. Teaser Campaign Image for Facebook}
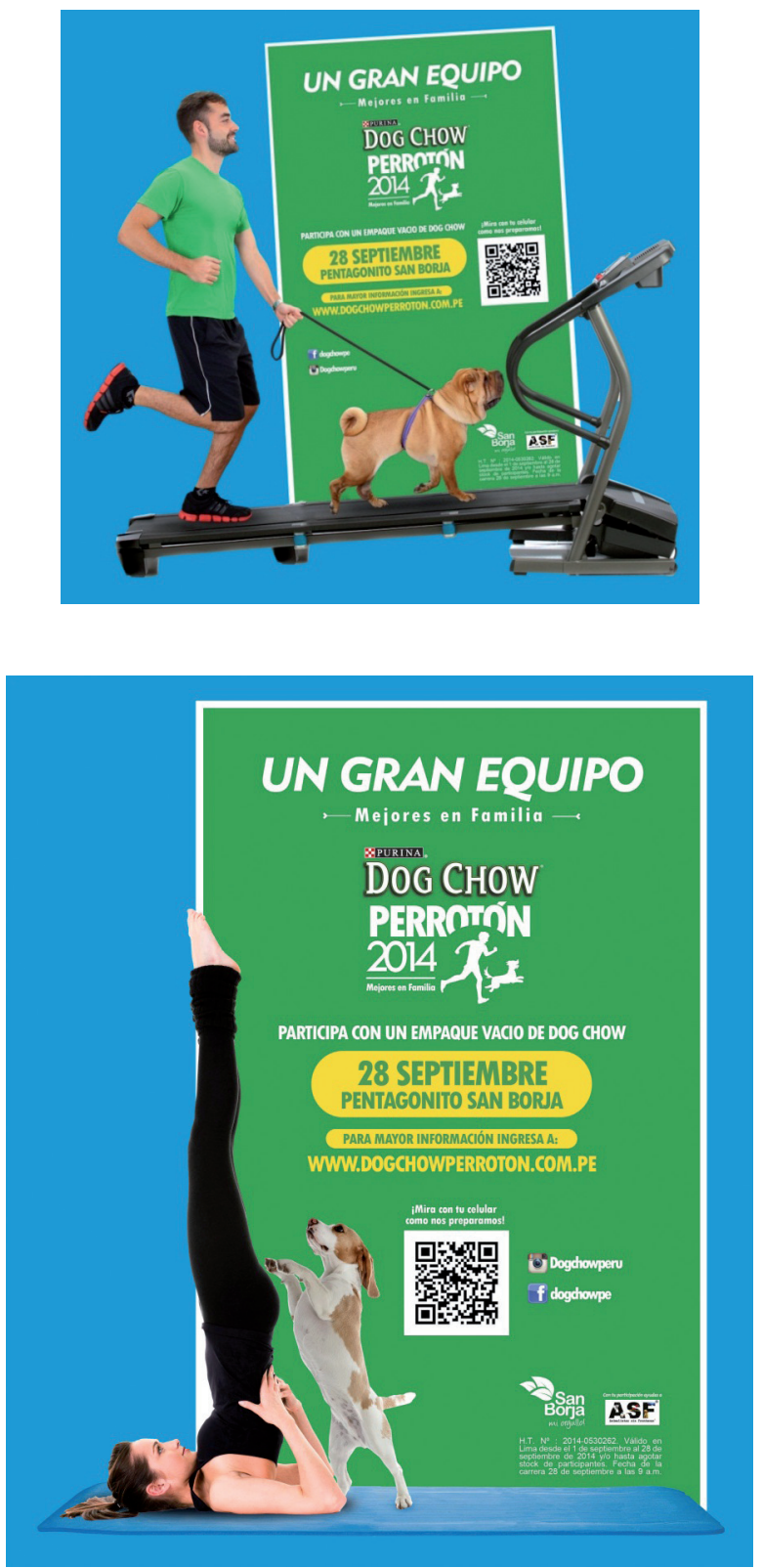


\section{Phase 2: Reveal and Announcement}

This phase was carried out through viral videos on social networks such as Facebook and YouTube. POP materials were also installed at points of sale through the traditional and modern channel.

\section{Viral Video on Social Networks 1}

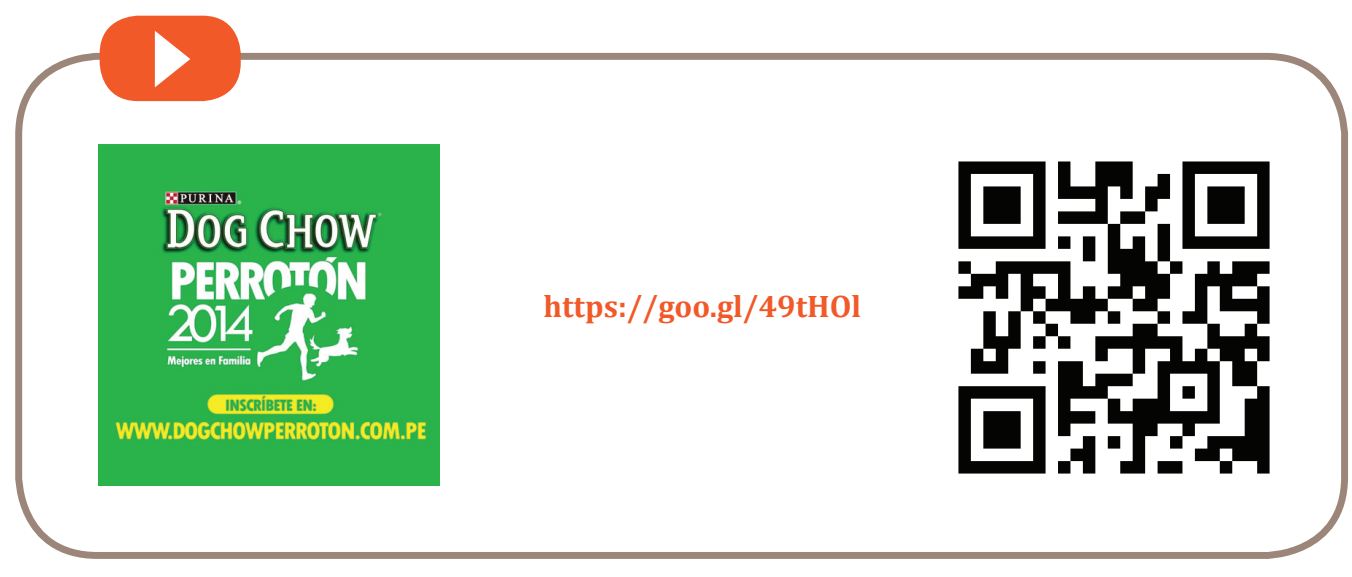

Viral Video on Social Networks 2

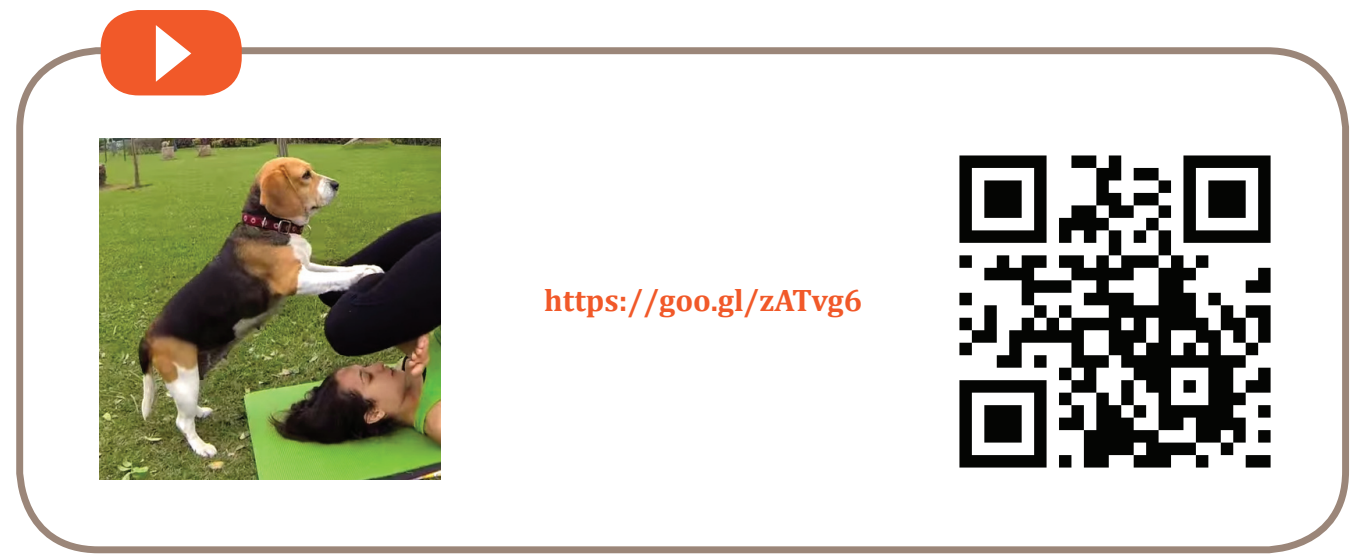




\section{Phase 3: Registration}

A website was created for the promotion and registration to the event ${ }^{1}$. The first one thousand people to register would have the chance to run with their pets in the Dog Chow's Perrotón 2014. However, the families that did not have the chance to register had free access to the family walk and the festival and its activities. It is worth noting that the use of radio or television broadcasting was not required because the participants' maximum number was reached during the website's first week of launching.

\section{Image 2. Campaign Website}

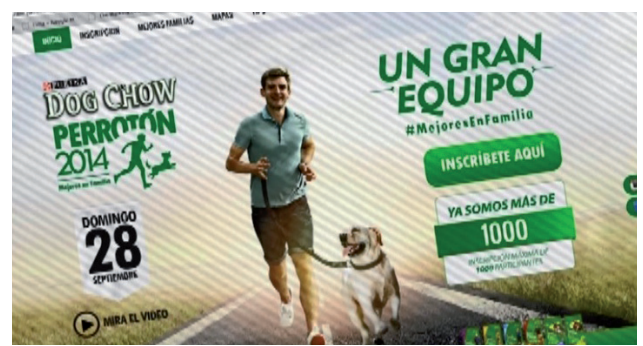

\section{Phase 4: Vet Check-Up and Participant's Kit}

Two days before the event, tents were installed for the people who had registered to pick up their kits and have their pets checked up.

\section{Phase 5: Event's Main Day}

The event was held on September 28, on the Pet's corner (Av. San Borja Sur and Boulevard San Borja). Unlike past years, the main activity of the event was the festival and the activities held geared towards sharing family time with their pets.

Now, in order to communicate this campaign and generate mass participation, promotion was also performed at points of sale, the streets, and digital media.

1 www.perrotondogchow.com.pe 


\section{Point of Sale}

Packages and materials were used at points of sale in order to communicate the invitation and its rules.

This was important because Purina Dog Chow's Perrotón requires that, in order to participate, individuals purchase a package of any presentation from the product portfolio, so the pet can be registered by the veterinarian before the competition, and the weight (in $\mathrm{kg} / \mathrm{lb}$ ) in the package be donated in food, at the end of the event, to the various animal shelters in Lima managed by Asociación Animalistas sin Fronteras.

\section{Streets}

Life-size images of owners and their pets training for the Dog Chow's Perrotón 2014 were placed at Pentagonito de San Borja, a high-impact location for the target audience. Digital media communication was emphasized in every material so as to turn this case into a social network trend.

\section{Media Campaign}

The campaign was planned so as to integrate all important contact points. Hence, the media agency and the digital agency were involved in the creative briefing process since the conception of the idea. This way, the agencies had more time to find the best way to maximize the message, making each contact point work for the message and not vice versa.

\section{Press}

Before, during and after the event, impact was achieved for free in the main printed and digital media. For that purpose, the Corporate Affairs team and Métrica agency were involved by providing their support with this task.

These impacts were achieved, among others, through 15-minute interviews in one of the main and most watched news programs in the country, Punto Final. 


\section{Digital Campaign}

Digital media were relevant in each phase of the campaign's communication. Platforms such as Facebook and Instagram were used and a YouTube channel was opened to broadcast all information or tips for all followers.

In addition, the website was launched and it was able to obtain the maximum number of participants just in the first week. However, it would continue to be visited thanks to its informative content.

Two viral videos that showed the great relationship between a dog and its owner and how they trained together were created and obtained more than 700,000 views.

To this, communication in the different digital touch points such as Facebook and Instagram was added. On Facebook, the brand obtained 2,564 new followers and more than 3,000,000 visitors during the campaign; on Instagram, the brand doubled its followers and more than 300 photos were uploaded with the \#hashtag \#mejoresenfamilia.

\section{RESULTS}

The most evident result is the growth percentage in market share. In relation to 2013, the brand gained two points in market share from the total category, achieving $72 \%$. In the Puppy Premium category, the brand gained 5 points, from $62 \%$ to $67 \%$ of market share 2 .

Thus, sales showed an increase of $42 \%$ versus last year's same period, growing above the category.

In relation to the return on advertising investment, free impacts were achieved in the main printed, digital and televisual communication media, valued in USD 640,000.

Good impact results were also achieved in the objective group. When comparing the brand awareness, correct association, and understood message levels with the brand's other campaigns in 2014, we can see that the «Mejores en familia» campaign was able to position itself in the objective audience's mindset and to maintain itself in all its publications almost half a year after the event.

Regarding the digital campaign objectives, the objectives established were surpassed with the digital media mix used for the «Dog Chow's 'Mejores en familia' 
Perrotón», with the following results:

- Free impacts in mass media, valued at USD 640,000.

- 1,200 registered people at the event

- 4,500 participants at the festival

- More than 687,188 views of YouTube videos.

- Engagement rate from $0.35 \%, 1,368$ likes and 270 comments

- 2,564 new Facebook followers and 3,077,400 people saw the page during the promotional days

- 325 new Instagram followers, double the campaign's initial figure

- More than 300 photos uploaded to Instagram with the \# hashtag \#mejoresenfamilia expressing the campaign concept

\section{General Compliance of the Business Objectives}

Market share, in volume, went from $70.0 \%$ in 2013 to $72 \%$ in 2014, and the Puppy Premium market share, from $62 \%$ in 2013 to $67.0 \%$ in 2014 . In brief, based on this campaign, the brand grew in volume, value and profitability above the objectives set at the beginning of the year.

However, the impact of this campaign goes beyond the commercial results, because it also contributed, in its own way, to integration and social inclusion. It promoted integration since it provided a recreational space for families and their pets, which are part of family. It promoted responsible pet ownership and the important role pets have in people's lives. Additionally, the mechanics of this campaign was designed with a social purpose, aimed at helping different animal shelters in Lima that receive an amount of complete and balanced food equal to the weight in pounds/kilos collected in empty packaging brought in by the participants.

Another important result is that 12 dogs found a home and a family, promoting responsible pet ownership because «a dog is a better dog when it has a family and a family is a better family when it has a dog.»

So, the campaign success keys could be summarized in the next points: 
- The brand sought consistence in its communication, working in the Purina Dog Chow's brand message «a dog is more than just a dog, it is part of the family.»

- A trend was created in digital media through the \#hashtag \#mejoresenfamilia, which was used to clearly express the brand belief and position it in the mindset of the target audience.

- Due to the strong reception of the event year after year and the good teaser campaign carried out in September 2014, media broadcasting such as TV, outdoor advertising, radios, among others was not necessary because the maximum number of participants was filled in just a week after registration began.

This case presented a highly-creative proposal by gathering a large number of families with their pets and motivating them to change their routine for a weekend, so that they could enjoy a space which not only offered the opportunity to practice sports with their pets, but also to participate in a festival with different activities designed to be shared together. It also gave families the opportunity to be together to root for the runners; many of these cheer teams prepared in advance with especially designed T-shirts, balloons and banners.

Lastly, the festival allowed exhibiting the other brands in the Nestle Purina portfolio such as moist Dog Chow and snacks, creating awareness in the public, a target that is loyal to the Purina Dog Chow's brand.

This campaign is supported by a trend based on the increasing care for our pets and the powerful insight: pets are loved as part of the family. Undoubtedly, the success of the campaign and of the results lies in there. 


\section{Opinion}

Understanding the consumer is the key to land successful marketing strategies. Purina Dog Chow's Perrotón case is an ideal example in which the brand is able to understand a valuable insight: «a family is a better family with a dog, and a dog is a better dog because it has a family.» From that insight, a huge communication campaign was worked on, a campaign that included digital media (Facebook, YouTube and Instagram), being thus able to get close to the consumer, increase brand awareness and above all, increase market share.

Mg. Luis Felipe Rodríguez B., MA International Marketing, Strategic Marketing Concepts and Strategic Marketing Tools Professor at UPC 


\section{BCP Mobile Banking}

Company's name:

Banco de Crédito del Perú

\section{Agency:}

Wunderman Phantasia

Category:

Digital Media - Services 


\section{YBCP'}

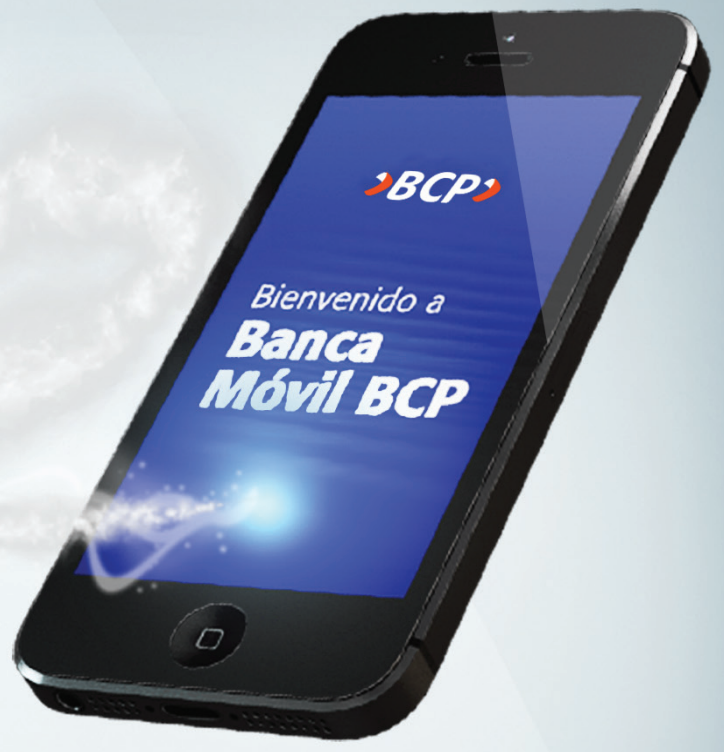

\section{Banca Móvil BCP}

Tus amigos de confianza se unieron para ti. 


\section{BCP: Unstoppable Evolution in Mobile Banking}

BCP decided to launch a new app for its Mobile Banking that could actually connect the users' two «trusted friends»: the bank and the smartphone. A better experience and usability for its users are not the only results, the number of Cellphone and Mobile Banking users rocketed to more than 340,000, which raised BCP's share by $43 \%$ in currency transactions.

\section{BACKGROUND}

Nowadays, banks meet their customer's needs by using digital platforms; BCP allows its customers to make banking queries and operations from their cellphones, from any mobile carrier, quickly and safely. They can also find nearby customer service locations and discounts easily. This in addition to the fact that mobile banking has a lower transaction cost than at the teller, generating savings for the bank. Therefore, the financial system is migrating more to mobile phones, which is creating immediate-response relations.

This situation is possible because the percentage of individuals using Internet and mobile phones creates the opportunity, as shown in Figure 1. 


\section{Figure 1. Internet and Mobile Phone Access in Peru}

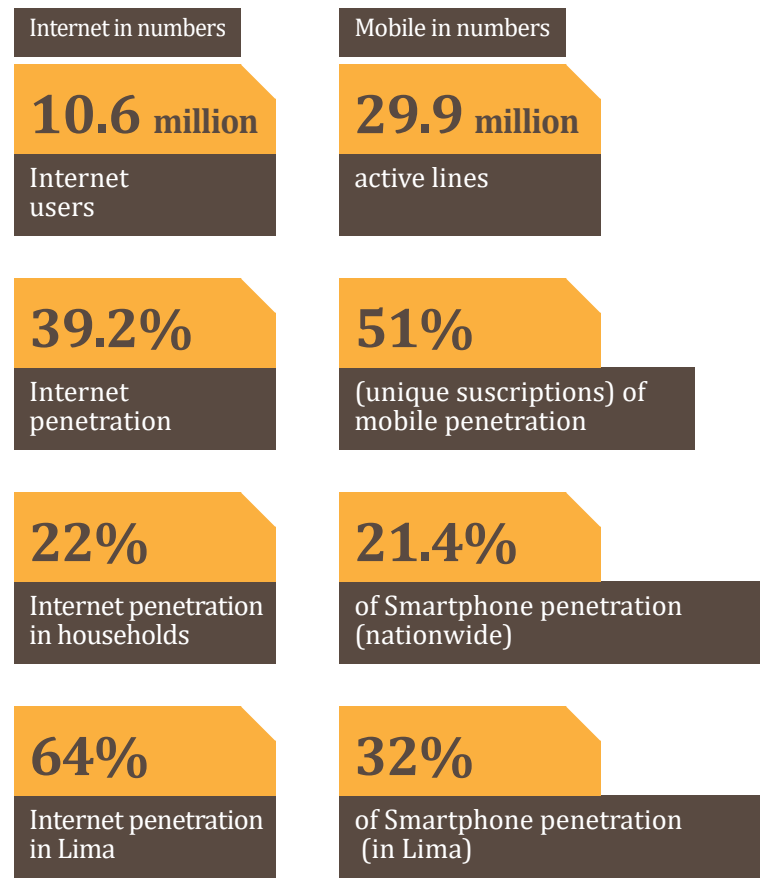

Source: Google Study «Household Use of Information Technology and Communication 2014,» and GSMA Intelligence Study

Before the new app launch, BCP already had Cellphone Banking, a transaction mobile tool that allowed three operations: balance and transaction inquiry, transfers, and adding funds to cellphones.

This channel user growth was significant. Between 2008 and 2009, 20,000 customers signed on. The following year, with the use of BlackBerry, the number increased by 165\%. In 2011, the app was adapted for iPhone, reaching 99,000 users. Between 2012 and 2013, it was enabled for Android, allowing 145,000 users. BCP maintained its leadership in the use of Cellphone Banking in the country. By 2014, BCP decided to keep this margin, improve the quality of the users' experience, increase functionalities, and decrease the gap between enrolled customers versus competition.

For that, BCP had to face two difficulties. The first was the impossibility for current cellphone banking customers to upgrade the app, i.e., to update the old tool with the new BCP Mobile Banking. In order to use it, the customers needed to download 
the app from the corresponding store and sign on again. Therefore, the campaign had to motivate customers enough to follow this process.

Another difficulty or challenge was that the Cellphone Banking 2013 app was positioned as a tool that did not have a good level of usability and had limited functionalities. But an opportunity was added to all this: at the end of 2013, the smartphone penetration in Peru was $17 \%$.

\section{The Proposal}

BCP Mobile Banking is a service channel that evolves keeping the pace with technological advances. It offers customers security, ease of use and benefits to make financial operations anytime, anywhere.

In this sense, in February 2014, the new app for iPhone and Android smartphones was launched, inproving the user's experience with the following 11 functionalities added:

1. Inquiries. Online consultation of savings and credit card accounts.

2. Reminders. Saves dates and sends messages for managing future payments.

3. Transfers between the holder and third parties' BCP accounts.

4. Credit card payments.

5. Adds funds to cellphones. Includes adding funds to own and third parties' mobiles.

6. Shared payment. Divides accounts among individuals, sends notifications and reminders.

7. Notifications. Important information about BCP accounts and cards.

8. Maps. BCP channel geolocation.

9. Cash withdrawal. Allows using the unused credit of a credit card.

10. Contact Us. Contact with a BCP officers or Telephone Banking.

11. Favorites. Saves frequent accounts as favorites in order to make banking operations without using the Digital Token in the future. Share payment functionality is worth highlighting. This tool allows a group of BCP users to divide a payment or service bill. To do so, one of the users assumes the total payment and the app allows the others to transfer him/her the corresponding amount. With this functionality, users are able to divide bills among friends easily, organize their group expenses, and always pay the exact amount. In addition, they are able to pay the assigned amounts directly and send reminders to participants that have not paid yet. 


\section{Image 1. Mobile App - Shared Payment Function}

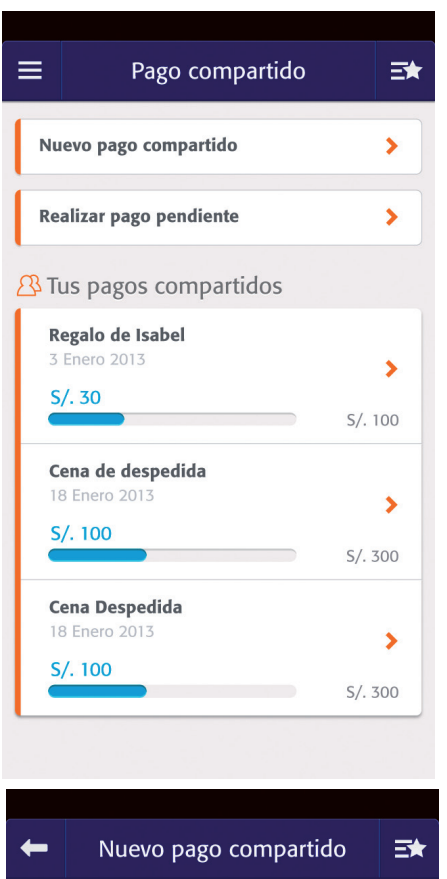

(1) 23

\begin{tabular}{|c|c|}
\hline \multicolumn{2}{|l|}{$\begin{array}{l}\text { Concepto } \\
\text { Regalo Isabel }\end{array}$} \\
\hline $\begin{array}{l}\text { Cuenta de dest } \\
\text { Cuenta Ahorr } \\
12312345698\end{array}$ & \\
\hline S/. 50 & Total pago compartido: S/. 300 \\
\hline $\begin{array}{l}6 \text { Participantes } \\
\text { Tú } \\
\text { Pedro (pedro } \\
\text { María (maria } \\
\text { Isabel (isabel } \\
\text { Juan (juan@g } \\
\text { Thais (thais@ }\end{array}$ & $\begin{array}{l}\text { ail.com) } \\
\text { ail.com) } \\
\text { ail.com) } \\
\text { com) } \\
\text { (.com) }\end{array}$ \\
\hline \multicolumn{2}{|c|}{$\begin{array}{l}\text { Confirma que los datos ingresados son correctos } \\
\text { antes de ingresar tu Clave Digital Token. }\end{array}$} \\
\hline Cancelar & Aceptar \\
\hline
\end{tabular}
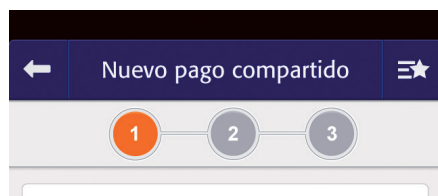

Concepto

Introduce el concepto del pago compartido

\begin{tabular}{|l|}
\hline Cuenta de abono \\
\hline Cuenta Ahorro Soles \\
\begin{tabular}{ll}
12312345698073 & S/. $3,250.23$ \\
\hline
\end{tabular}
\end{tabular}

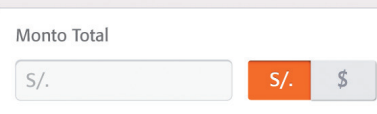

$\square$ Participantes
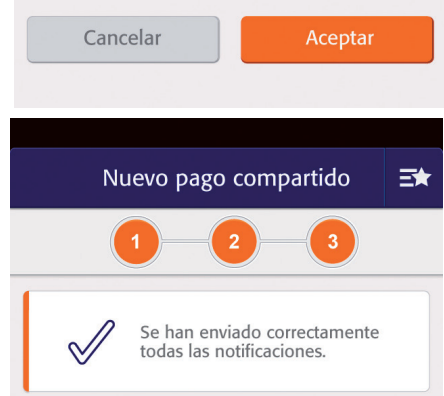

Concepto

Regalo Isabel

Cuenta de destino

Cuenta Ahorro Soles

12312345698073

Monto

S/. 50

Total pago compartido: S/. 300

6 Participantes

Tú

Pedro(pedro@gmail.com)

María (maria@gmail.com)

Isabel (isabel@gmail.com)

Juan (juan@gmail.com)

Thais (thais@gmail.com)

Número de operación

35641A3214D321E

Volver a pago compartido 
BCP Mobile Banking is an alternative service channel that provides safety, convenience and promptness as its main attributes.

It is a safe channel because the transactions are validated with a Digital Token password, which eliminates the risks derived from cloning or unauthorized used by third parties. It is convenient because it is available 24 hours a day and can be used in any place that has coverage. In addition, in order to provide a differentiated experience to the Enalta $\mathrm{BCP}^{1}$ customer base, a special app was developed for them. Finally, it is quick because several transactions can be made in seconds.

Then the proposal was for BCP Mobile Banking to establish a convenience and accessibility relationship to benefit both the customer and the financial company.

The specific objectives set out before the beginning of the campaign were the following:

1. Achieve a $50 \%$ conversion ratio (87,500 memberships and 175,000 downloads.)

2. Increase banking operations and transactions by $25 \%$ as compared to the previous year.

\section{THE IMPLEMENTATION}

In order to notify of the new mobile app launching, BCP built a digital ecosystem supported on three platforms:

1. An interactive video in YouTube

2. An experience and information website

3. A landing page on VíaBCP 


\section{Figure 2. Digital Ecosystem}

Roles

Conversion

Engagement

Awareness

Contact points

Virtual shop

Platforms

Online media

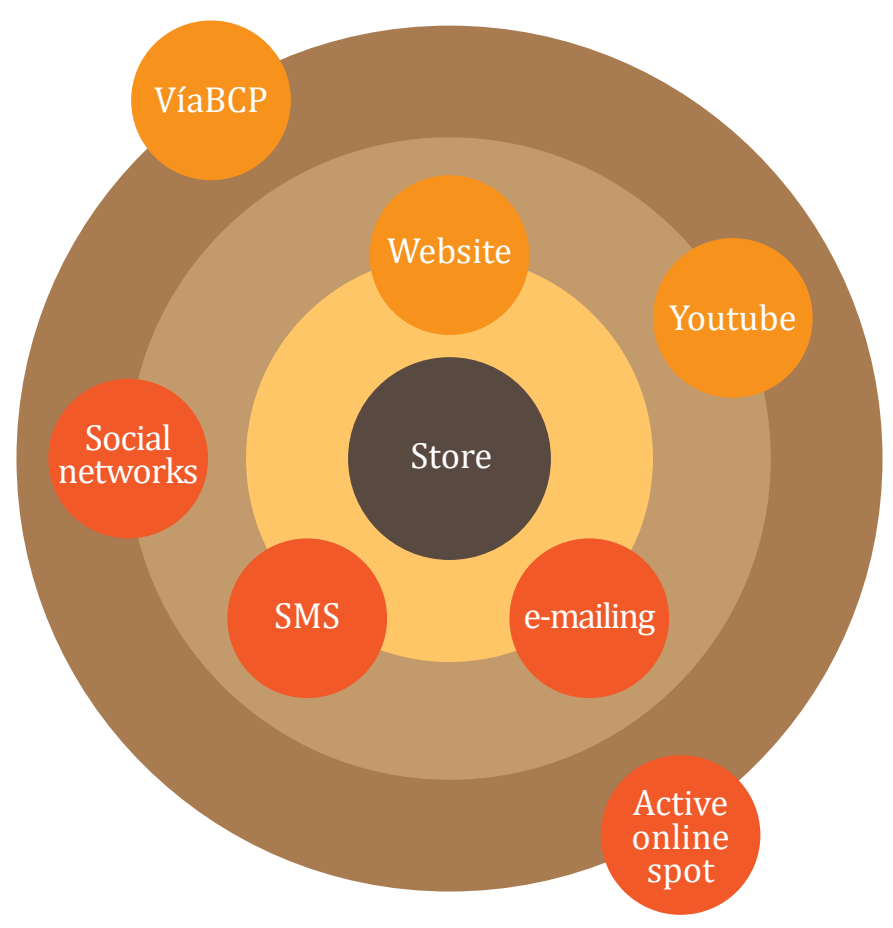

Source: BCP

The interactive video actually consisted of four interactive videos in a single YouTube view. The storytelling was about the way Jorge, the main character, solved three everyday situations from where he was, with the help of his two trusted friends: his smartphone and BCP, both of them personified. The fusion of these two created BCP Mobile Banking. 


\section{Interactive Video}

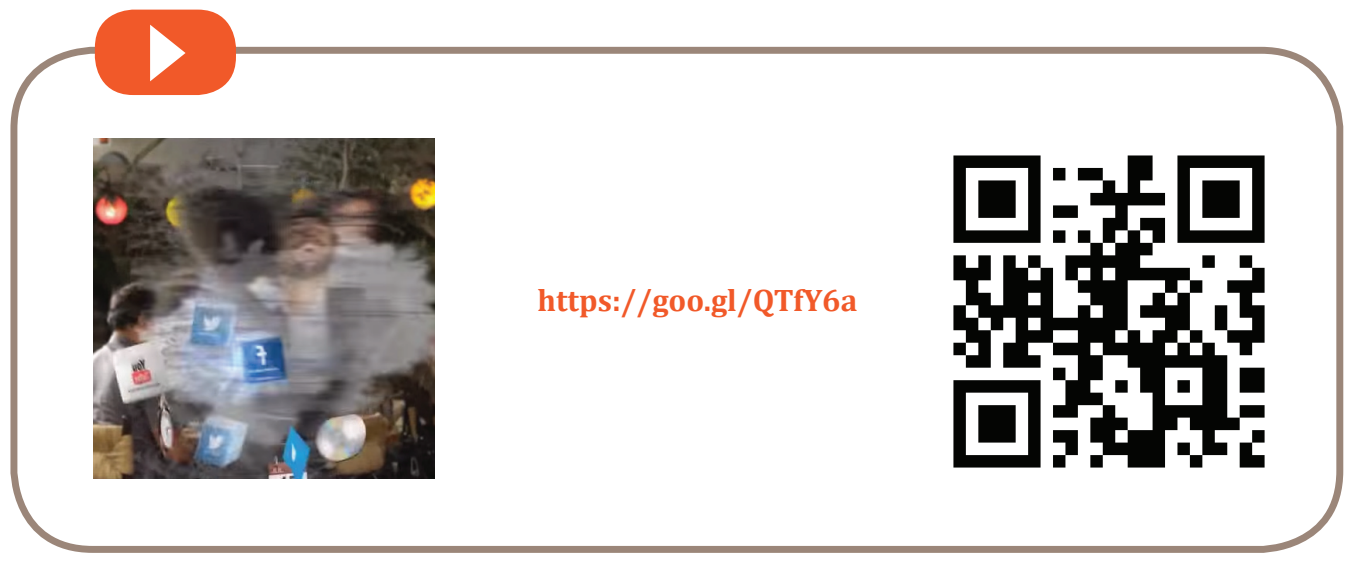

In order to train the users in the practicality of the app, an informational site with a mobile version was designed. For the first stage, the «ScrollTelling» version was published, and consisted of showing the fusion of BCP Mobile Banking characters, as an introduction. In order to do this, stop motion was used as a resource: eight head turns were designed and photographed. With stop motion, a whirlwind of images was also created, so that the «image» characters of the campaign, the Bank and the smartphone, were able to move. The animation became active only if the user scrolled the mouse or used the navigation bar. With this experience, the fusion of these two characters in BCP Mobile Banking was explained interactively and playfully.

After that, as a maintenance stage, the site was optimized, hiding the introduction to focus on the seven tutorials that taught step by step how to sign in as well as the operations of the mobile app. 


\section{Image 2. Scroll Mouse Animation}
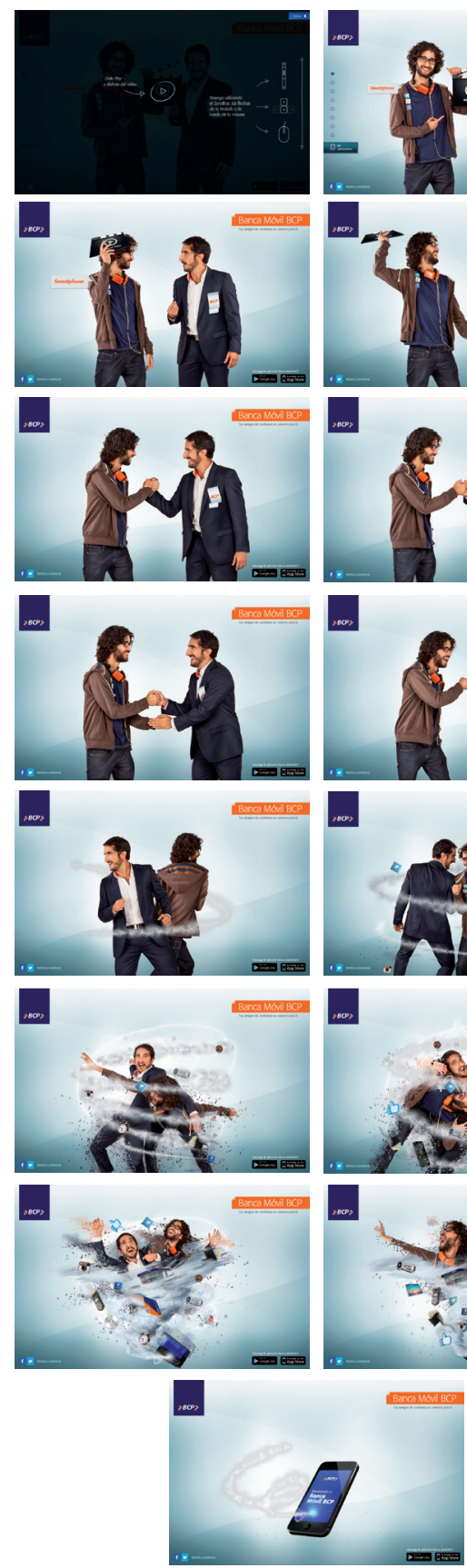
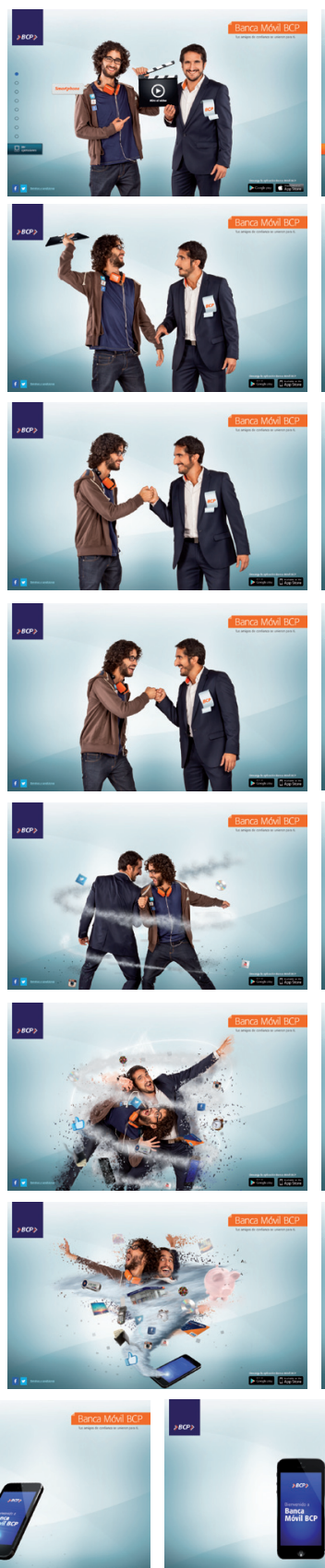
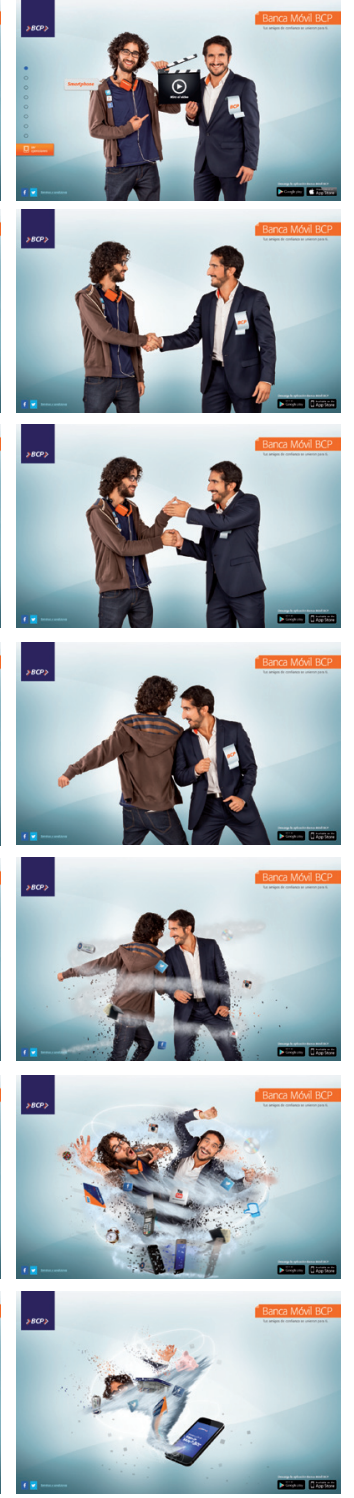

BancaMBan BCP 
Social networks were also used to generate content and conversation. In order to do so, infographics were designed, covers were dressed and standard answers were prepared, with technical support to solve the followers' questions and needs.

Also, CRM mailing was created for each bank customer base and SMS were sent to customers for them to download the new app. In digital media, the following was proposed: frame ads and Rich Media to generate print outs, Search and Display for web traffic, and Ads in mobiles to promote downloads for smartphones.

It is worth mentioning that the VíaBCP landing page was second place in SEO positioning level, and the experience site was third place in Google searches, despite the fact that the last one was a One Scroll Page. For this, 10 branding keywords positioned in the top 3, and 5 no-branding keywords positioned in the top 5 were associated, which resulted in a $150 \%$ increase in organic visits.

\section{An Experience and Information Website}

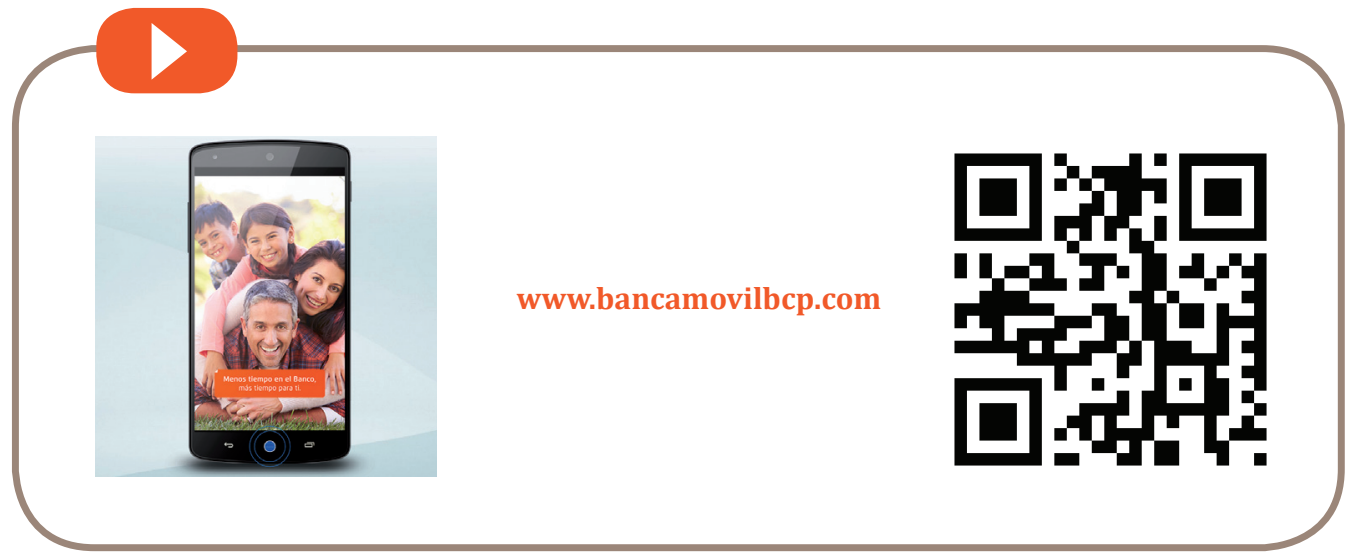

\section{RESULTS}

Through this campaign, BCP reached and exceeded the objectives set out for the new mobile app use.

243,531 downloads were reached, that is to say, $28.14 \%$ more than the initial objective Therefore, from August 2013 to August 2014, the amount of downloads grew by $203 \%$. During this period, the number of memberships grew by $610 \%$, reaching a conversion ratio of $70 \%$ (memberships/downloads). 
Regarding the app use, the banking operations and transactions grew by $347 \%$ as compared to the previous year. Thanks to this, BCP is still the leader in the currency transactions share of Mobile Banking in the financial system (43\% in 2014) 2 .

Another important achievement is that the gap between member consumers versus the competition was reduced. BCP Mobile Banking obtained 122,000 new members compared to the previous year.

A relationship of «convenience» that benefits both the customer and the financial institution was created. The transacted amount grows at a 40\% rate (CSC - Customer Service Center).

It is important to emphasize that the mobile app is a channel with a transactional cost 24 times lower than the teller, that is why it is considered an effective alternative not just for customers, but also for the enterprise.

Additionally, as for the results of the advertising campaign, the following was observed:

- $\quad$ More than 182,000 print outs.

- $\quad 233,507$ online video views and 4,737 tutorial views.

- More than 171,000 single visits to the site.

- A 150\% organic web traffic growth and 10 branding keywords positioned in the top 3, and 5 non-branding keywords positioned in the top 5 of Google searches.

- The total bonus, for different types of purchases in digital media, represented 75\% of the digital investment for the BCP Mobile Banking campaign.

- An average $0.04 \%$ engagement rate in Facebook, with $73 \%$ of positive sentiment of the BCP mobile banking publications, becoming national news.

Additionally, BCP Mobile Banking won the Latin American «Best Mobile Banking Service of the Year» in the Mobile Payment Awards 2014, an IAB Digi de Oro (Award for Best Digital Communication) as «Mobile Platform 2014 in Peru,» and «Best Mobile Banking Service,» according to the 14th Annual Survey of Executives from the Lima Chamber of Commerce 2014.

The virtual and digital world is a marketing trend; everybody, not only digital natives, wants to do everything with their cellphones. This campaign connects perfectly in this sense, it is something that the market had been asking for loud and clear. The results show the success of the campaign, but also leave an open door for the opportunity to perform more financial activities and banking transactions through the mobile platforms. 


\section{Opinion}

Nowadays, the digital field leads the modern marketing trends, and it also contributes to the development of new tools that facilitate immediacy, the use of social networks, and the possibility to measure, in truth, entrepreneurial strategies. This way, Mobile Banking brings the bank, the smartphone, and the customer together. This marketing strategy related to the evolution in Mobile Banking encourages the following functions through a mobile transaction tool: balance and transaction inquiry, transfers, and even adding funds to cellphones. This involves a transactional cost lower to the teller's, and thus gives a quick and safe beneficial option to their customers. This is a successful case that refers to the implementation made for launching the project, building a digital ecosystem supported on three technological platforms, and that obtained a welldeserved international recognition.

Jorge Bohorquez

Marketing Plan Design Professor at UPC 



\section{Pilsen Callao: a Fresh Consistency That Keeps Generating Value and Volume}

Company:

Unión de Cervecerías Peruanas

Backus \& Johnston

Agencies:

Publicis/Wunderman Phantasia

\section{Category:}

Advertising Brand 


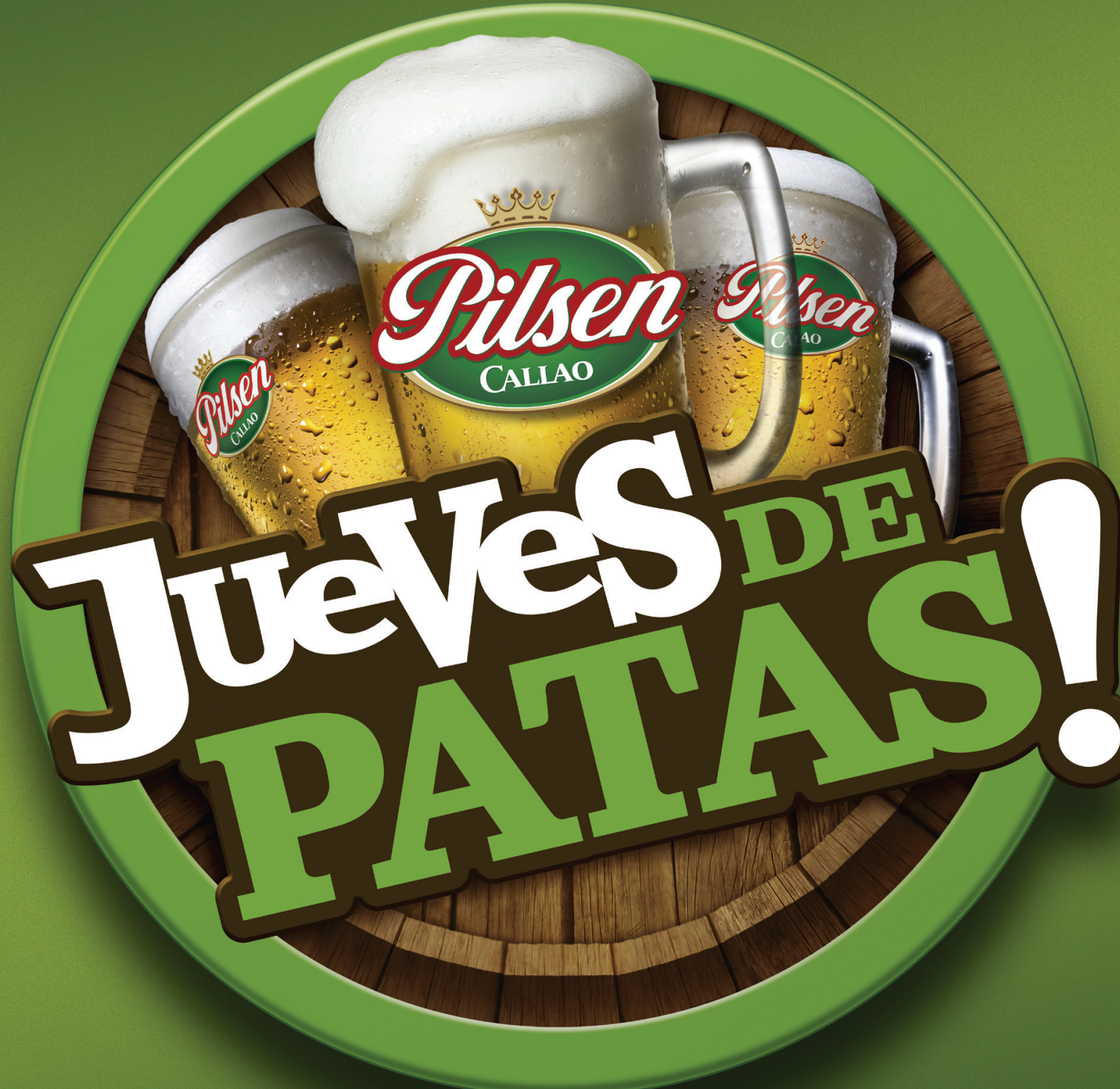




\section{Pilsen Callao Evokes the Excitement of Friendship from Yesterday, Today and Always}

In 2013, the Pilsen Callao beer brand evolved to connect with the consumer through a more emotional and less rational message: «The taste of true friendship.» Since then, the brand started to grow and became more relevant for consumers, thus achieving great results in the market. The challenge for 2014 was, amidst a more complex market, to consolidate this approach and surpass the great results obtained.

\section{BACKGROUND}

2014 was a harsh year due to two main factors that had an impact on the brewing industry. On one hand, the Peruvian economy slowed down: growth was projected at $5 \%$, but it reached only $2.3 \%{ }^{1}$. On the other hand, the beer category remained within a stagnation period it had been immersed in since 2013; therefore, it only grew $1.6 \%{ }^{2}$.

Adding to this situation, two new world-class beer brands entered the brewing category: Löwenbraü and Budweiser. Both of them invested aggressively on advertising and took over important sponsorships for the target audience-like the World Cup, in the case of Budweiser. Löwenbraü was trying to compete directly with Pilsen Callao and was using the brewery tradition argument because of its 600 year-old origin; therefore, it was competing on a similar price and target range as Pilsen Callao.

Besides, it should be noted that before 2013, Pilsen Callao was a brand with little differentiation within the beer category. Because of this, the brand evolved to connect with the consumer through a more emotional and less rational message. Thus,

1 INEI: Evolution of GDP in Peru

2 Ministry of Production: Beer Production, 2014 
the idea of a more real, approachable and honest brand for people was born: «The taste of true friendship.» Since then, the brand started to grow and became more relevant for consumers, achieving this way very good results in the market. In 2013, the brand grew $+17 \%$ in volume and $+24 \%$ in value contribution for the company.

The challenge for 2014 was to consolidate a strategic approach based on the foundation achieved in 2013, and surpass its results. The task consisted of developing a platform that was solid but freshly creative so that the brand could distinguish itself from the others and be relevant for the consumer. The final goal was to increase sales within a complex market context.

\section{The Proposal}

Pilsen Callao's brand proposal is based on a solid consumer insight: «I love my life, but I would like to have more free time to spend with my true friends because only around them can I be myself.» And Pilsen Callao's proposal is to introduce itself as the only brand that can fulfill this need because its goal is to «create and celebrate moments of true friendship.» Therefore, Pilsen Callao had to continue building in favor of the brand's evolution and a positioning that allowed connecting it strongly to the territory of true friendship, the territory of «buddies.» This way, during 2014, through a consistent strategy, the new proposal started in 2013 was reinforced: «Pilsen Callao: The taste of true friendship.»

The strategic plan consisted of an integrated activity program that allowed the short and long-term reinforcement of brand positioning and value. Each campaign had a role to fulfill within the strategy, besides building on the existing. This way, Pilsen Callao would increase brand value and volume in the category.

To this end, the strategy was based on three main pillars: the frequency to develop the category reinforcing a new consumption habit, storytelling to strengthen the emotional bond, and storydoing to bring the brand's purpose to life.

\section{THE IMPLEMENTATION}

Activities planned for 2014 had to bring the brand's narrative to life and fulfill a specific role within the strategy, always under the «true friendship» umbrella. The three pillars mentioned in the proposal were implemented as follows: 


\section{Frecuencia. Jueves de Patas (April-May)}

Leveraging on the Jueves de Patas (Buddies' Thursday) copy platform, the change in the category's consumption habits continued to be promoted. That is, friends were invited to get together on a weekday, regardless of the sacrifices implied in doing so.

The strategic goal of the Jueves de Patas (JDP) campaign is to increase consumption frequency during weekdays; and, since its launch, this habit change has begun to take place in society.

Pilsen Callao chose to focus on the consumption opportunity of «getting together with friends and family after work» in establishments where you can drink on weekdays. The perfect combination of its proposal and market positioning (27.7\%, Dec. $2013^{3}$ ), its magical price of PEN 4.00 and the brand's purpose- «create and celebrate true friendship moments»-make Pilsen Callao the perfect brand to lead this category's habit change.

The communication concept had to be built over the existing work (2013 «Cosito» campaign); that is, it had to be consistent with the proposal and role, but fresh thanks to a different campaign. That is how the concept of «Anything for Buddie's Thursday!» was developed. Every day, men make sacrifices in order to maintain the stability of their relationships, but there is something they can't sacrifice: getting together with their friends every Thursday Once again, this campaign involves the key elements: consumer, customer and sales force.

- Television. It was crucial to show a consumer's solid insight in a clear manner and to connect it with Pilsen Callao's narrative and Buddies' Thursday. And so «Sí mi amor» (Yes, my darling) was born: a group of friends that humorously reflect the feeling of a lot of patas (buddies), who must sacrifice some pleasures and wishes, but that can't give up the only valuable thing: getting together with their true friends on a weekday. 


\section{Cosito II Spot}

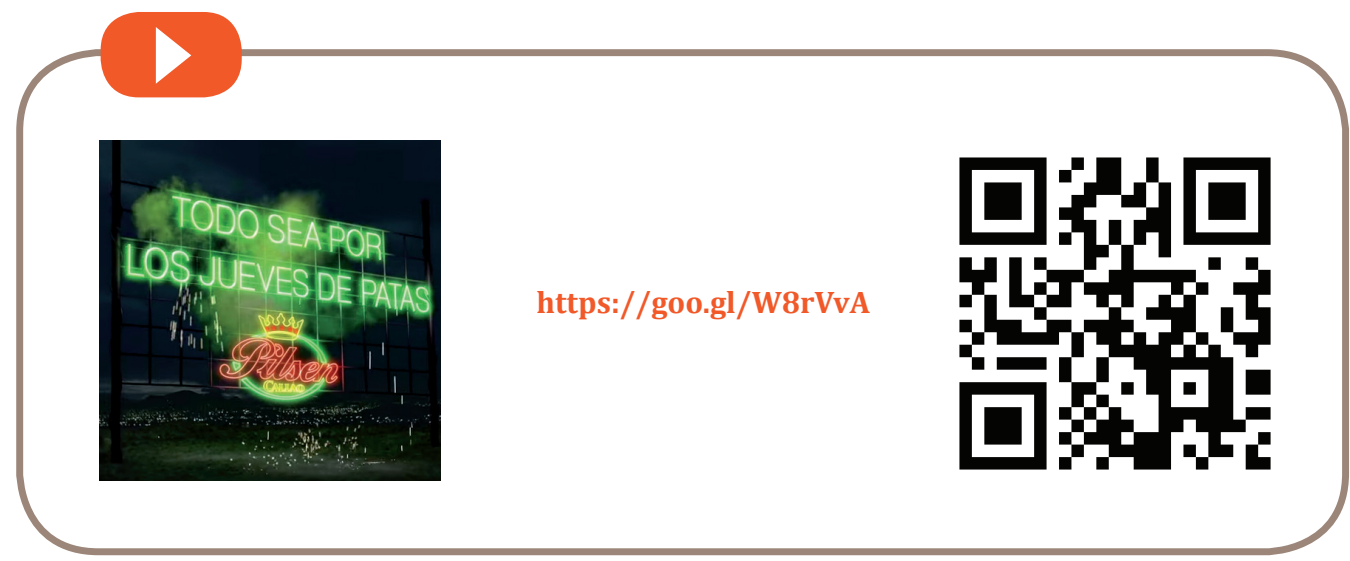

- Streets. The strategy consisted of placing impressive billboards and illuminated signs on all key areas reinforcing the message «Anything for Buddies' Thursdays!» Locations were strategic as these signs were placed on the routes going back home.

\section{Image 1. Billboard}

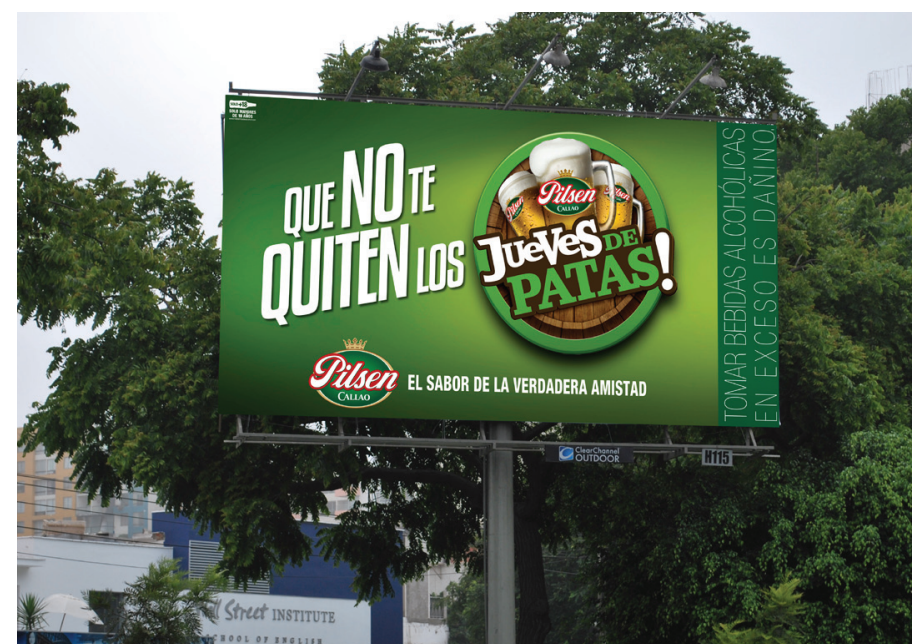


- Digital. This media was a key element to create and strengthen the connection between the brand and the copy platform. The strategy fundamentally consisted of producing more knowledge and consideration of the copy platform during the campaign period and year. As a result, there was a $+16 \%$ increase of interactions and the positive comments reached $84 \%$.

- BTL Activations. More activations took place nationwide, with greater consumer interaction, who took part in games in which groups of friends competed to win merchandising or free products. These activities reinforced and recalled the idea that every Thursday is Pilsen Callao's Buddie's Thursday.

- Point of Sale Materials. The elements were strategically located in key contact areas in bars; they were designed using special materials and dimensions to achieve a greater impact and permanence.

- Promotion. To build consumer loyalty, the 4x3 promotion was activated in 2,300 bars nationwide, thus creating campaign ambassadors. All participating bars received material and prizes for being part of the promotion. Pilsen Callao sales increased $49 \%$ at the activated bars and the category increased $16 \%$ in these places.

\section{Storytelling. Estar enamorados (July-August)}

To strengthen the emotional bond, the campaign Estar enamorados (Being in Love) was created; it linked the brand to the consumer by reflecting insights in a very funny way: evidencing «love» among true friends. This was a way of conveying the brand's message: to protect true friendship.

This campaign's concept revolved around powerful insights of real friendship, which showed in an ironic and funny way how we accept and love our friends regardless of their flaws. To increase visibility and awareness, an old song popularized by Spanish singer Raphael was used, while its lyrics were modified to associate it to true friendship situations that connected nicely with the audience. The different media joined this TV element in an integrated way. Advertising displayed on the streets covered a large area of Peru, showing a simple and iconic proposal. In social networks, discussions about love 
among buddies were promoted through actions that kept followers hooked, building brand engagement. All these messages were complemented with sponsorships in the most popular shows among the target audience in order to keep the concept fresh.

\section{Latidos de Amistad Spot}

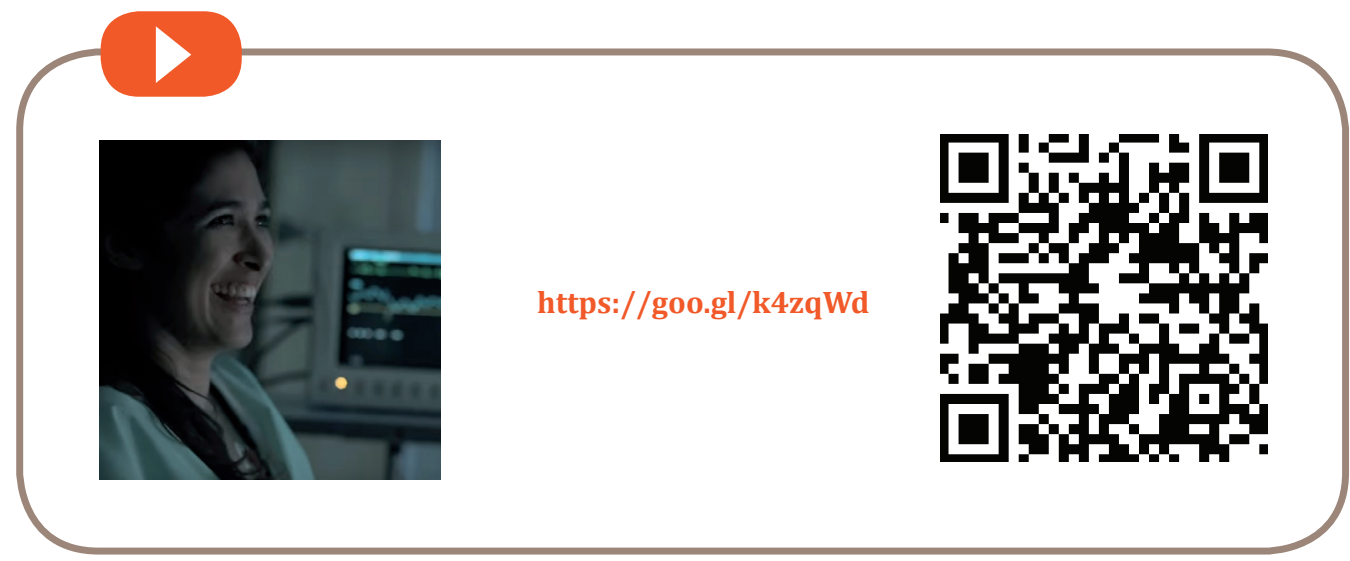

\section{Storydoing. Trae a tu pata (September-October)}

The brand purpose was again brought to life: «To create and celebrate moments of true friendship.» To this end, 100 groups of friends that for some reason had been separated were brought back together.

In 2013, Pilsen Callao launched its «Trae a tu Pata» campaign. The brand decided to launch it back in 2014, but there was a great challenge ahead: how to make this promotion to do better than the one from the previous year and, most of all, how to make it more attractive and not repetitive?

Pilsen Callao decided to use the memory structure strategy consisting in leveraging on some of the first version codes to achieve campaign and brand awareness and association, and also to turn it into a powerful brand property.

Trae a tu pata gave 100 groups of friends, separated for some reason, the chance to be brought back together, no matter where they were located. The idea was based on this insight: when a real friend is not around, nothing is the same. Reuniting friends would create new unforgettable memories. This insight not only reinforced the campaign 
during the first year, but also was the main reason why a lot of consumers that couldn't win the previous year, wanted to have another chance to bring their buddies back.

The process was improved and became more inclusive (it was easier to participate): each Pilsen Callao beer consumed brought their far-away friend closer to them. The only requirement was to collect kilometers from the caps or can openers, and the first 100 friends to gather 6,200 mi could bring their buddy back to celebrate true friendship together. Furthermore, instant prizes were awarded such as domestic trips for two and free products in order to keep consumers engaged.

This campaign had a significant display in different media such as TV, digital, radio, the street, point of sale material, packaging and support from a call center so as to facilitate and make consumer's participation more enjoyable.

- Television. To start the campaign, two advertisements were launched, one to connect emotionally with the consumer and the other to explain the process. When the participation stage ended, a third advertisement showing the winners' reunions with their groups of real friends was launched.

\section{Mercado Negro Article about the «Trae a tu Pata» Campaign}

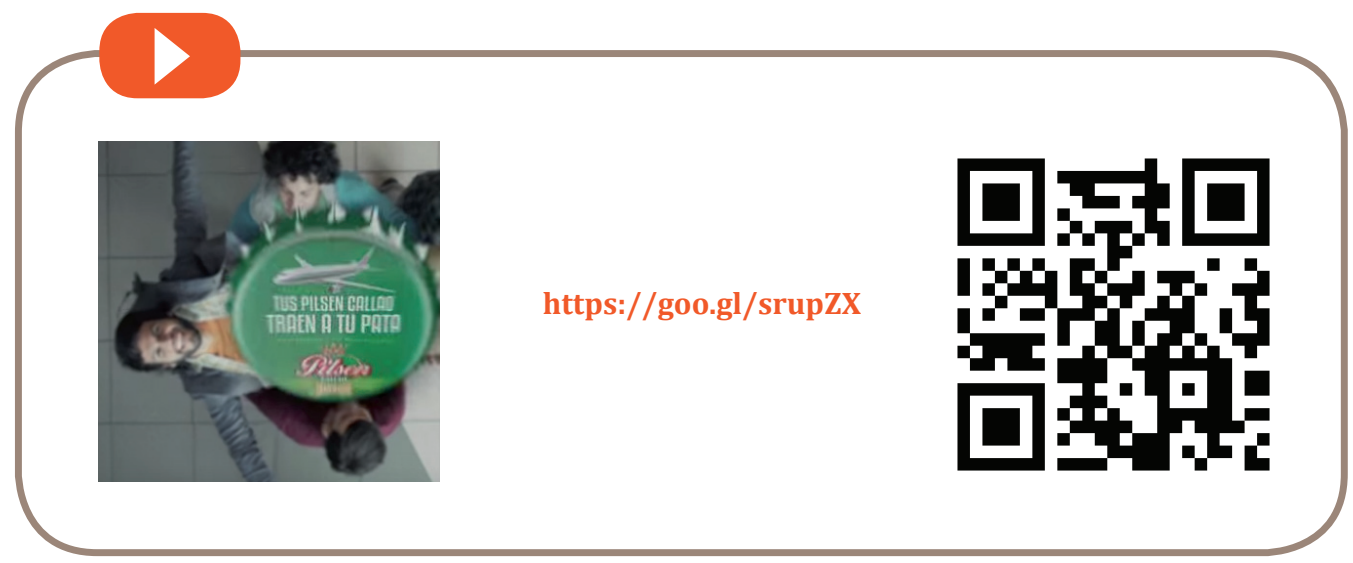


«Trae a tu Pata» 2014 Spot

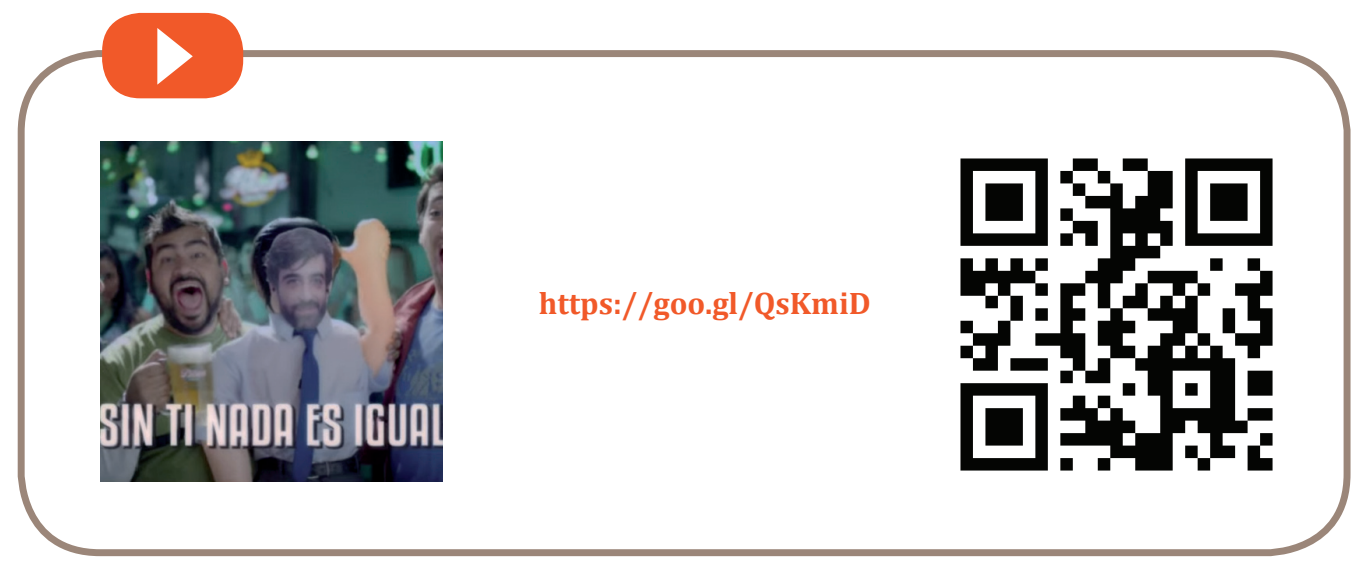

\section{Reunions Spot 2014}

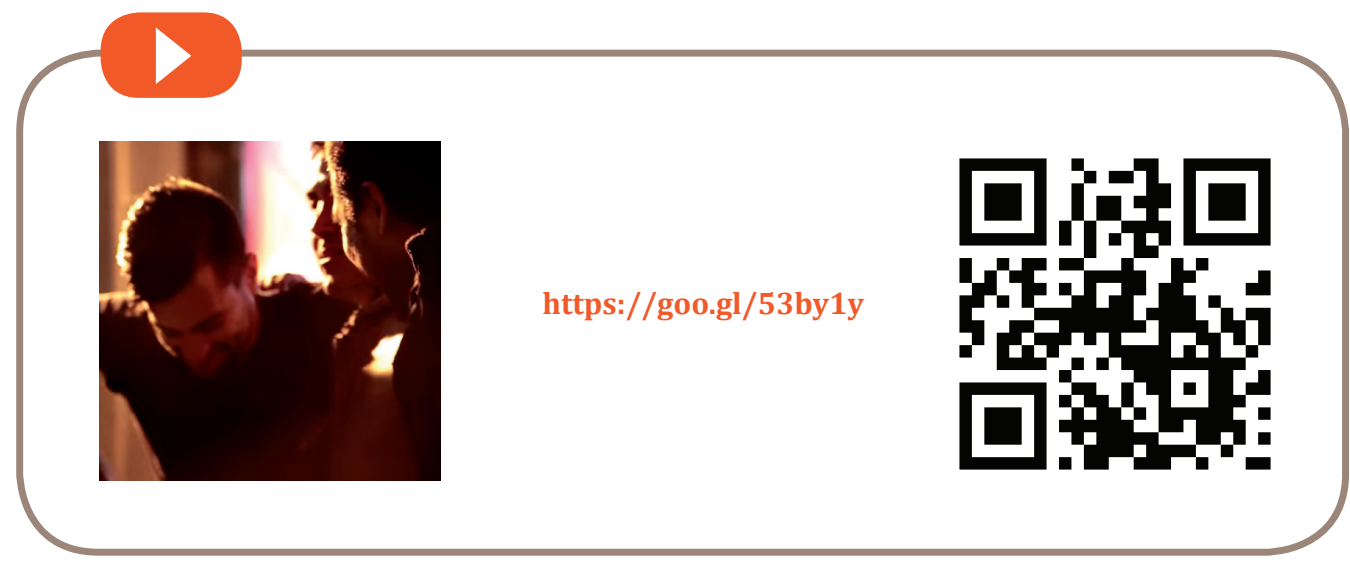

- $\quad$ Radio. It was used as a tactical medium for explaining the process.

- Digital. Digital media acted as a platform to promote consumer involvement, inviting them to beat challenges to win more kilometers. It also helped to keep track of the online chatting, gathering important information to correct and clarify every campaign aspect. This platform was also used to keep up with two real groups of friends, after their reunion at the airport. In this way, the consumer was able to get excited about real stories. 
- Outdoors. The most important icon of the campaign was used: the airplane, with the goal of getting quick prize awareness and desirability.

- Points of sale. Attractive and impressive materials were created; they promoted brand positioning and awareness and are kept by retailers to this date.

- Packaging. A special packaging was developed, giving visibility to the brand and allowing it to notify of participation instructions.

- Call center. Customers just had to send a free SMS with their national ID number to 50150 and, immediately, the dedicated line would get back to them to register them and provide instructions. The line was a key element to keep check of winners and solve any possible problem. This was a crucial improvement to the campaign, as it allowed a participation level increase of $809 \%$ in comparison with the previous year's.

\section{RESUltS}

In 2014, Pilsen Callao experienced an 18\% sale increase compared to the previous year ${ }^{4}$. It should be noted that it was the only brand within the national scope industry that achieved this level of growth within a category that basically kept the same levels of the previous year $\left(1.6 \%{ }^{5}\right)$. Due to its upper-mainstream role, this volume increase meant more than 125 incremental millions of soles as contribution for the company, which represents a $20 \%$ increase ${ }^{6}$.

The brand value maintained a growing trend all year long. This fact is a confirmation that, even if every campaign fulfills a specific role in meeting certain goals, all of them add to the strategic objective of building brand value, increasing from $32 \%$ (as of 2013 closing) to $41 \%$ (as of 2014 closing).

The sum of all campaigns consolidated Pilsen Callao's positioning as «the brand that celebrates true friendship.» KPI grew seven percentage points in one year, from

\footnotetext{
$4 \quad$ Business Objects 2014.

$5 \quad$ Ministry of Production 2014.

$6 \quad$ Financial Report 2014.
} 
$57 \%$ in 2013 to $64 \%$ in 2014 .

All these campaigns implemented in a coordinated manner during 2014 left the following lessons to the brand:

1. In spite of the fact that different brand actions respond to different objectives, all of them must be based on the brand narrative to reinforce the emotional bond, while the freshness of each of them promotes desirability and validity within the consumers.

2. It is necessary to move from speech to action and to assume a more active and central role in the consolidation of the brand purpose; i.e., to bring to life the brand narrative through powerful actions capable of resolving the consumer's tension.

3. The structural memory power allows transforming campaigns into real brand equities. Sometimes, you don't need to be creating new things continuously to offer every year; on the contrary, it may be better to build and improve an already successful formula.

4. The idea of each campaign is to win ambassadors for them and simplicity is the only tool to do it. Simple procedures allow for quality programs and high probabilities of commitment, involvement and thus campaign success.

5. Brand value can be generated and volume can be increased, even in an adverse context. Experience shows that it is possible to consolidate a brand (and make it attractive and close to the consumer), even if it is part of a mature category. Establishing a true connection with the consumer translates into short and long term sales increase.

The entire campaign is based on a very solid customer insight: «having more time to spend with my true friends because only with them can I be myself,» and Pilsen provides that opportunity. Besides, it took the challenge of not being repetitive in relation to the previous year's campaign; however it did use its powerful ideas as leverage. Results show that Pilsen achieved this goal and that, in addition, it reinforced its positioning as the beer of true friends. 


\section{Opinion}

Pilsen Callao's case is successful in different aspects: from the brand's target group's emotional perspective to the commercial point of view, by showing that a brand located in a mature market can consolidate itself even further. Pilsen was a brand within the portfolio that did not have a clear distinction, and it is here where the advertising agency and the brand management developed their strategic pillars: to reinforce the consumption habit and the emotional bond, and to create a brand purpose. These three pillars were responsible for the success of the campaign in 2014, registering an $18 \%$ sales increase (vs. 2013), exceeding market growth. This case proves that emotional bonds in marketing are very powerful tools on consumers, not only for tangible products - as it was shown with Pilsen-but also for intangible services.

\section{Carlos Semsch}

Commercial, Sales, Distribution and Trade Marketing Management and Strategic Marketing Concepts Professor at UPC 



\section{Field: 150 years with a lot of 'filin'}

Company's name:

Mondelēz Perú S.A.

\section{Agency:}

Momentum Worlwide (McCann

Worldgroup)

Category:

Digital Media - Products 


\section{0}

$=$.
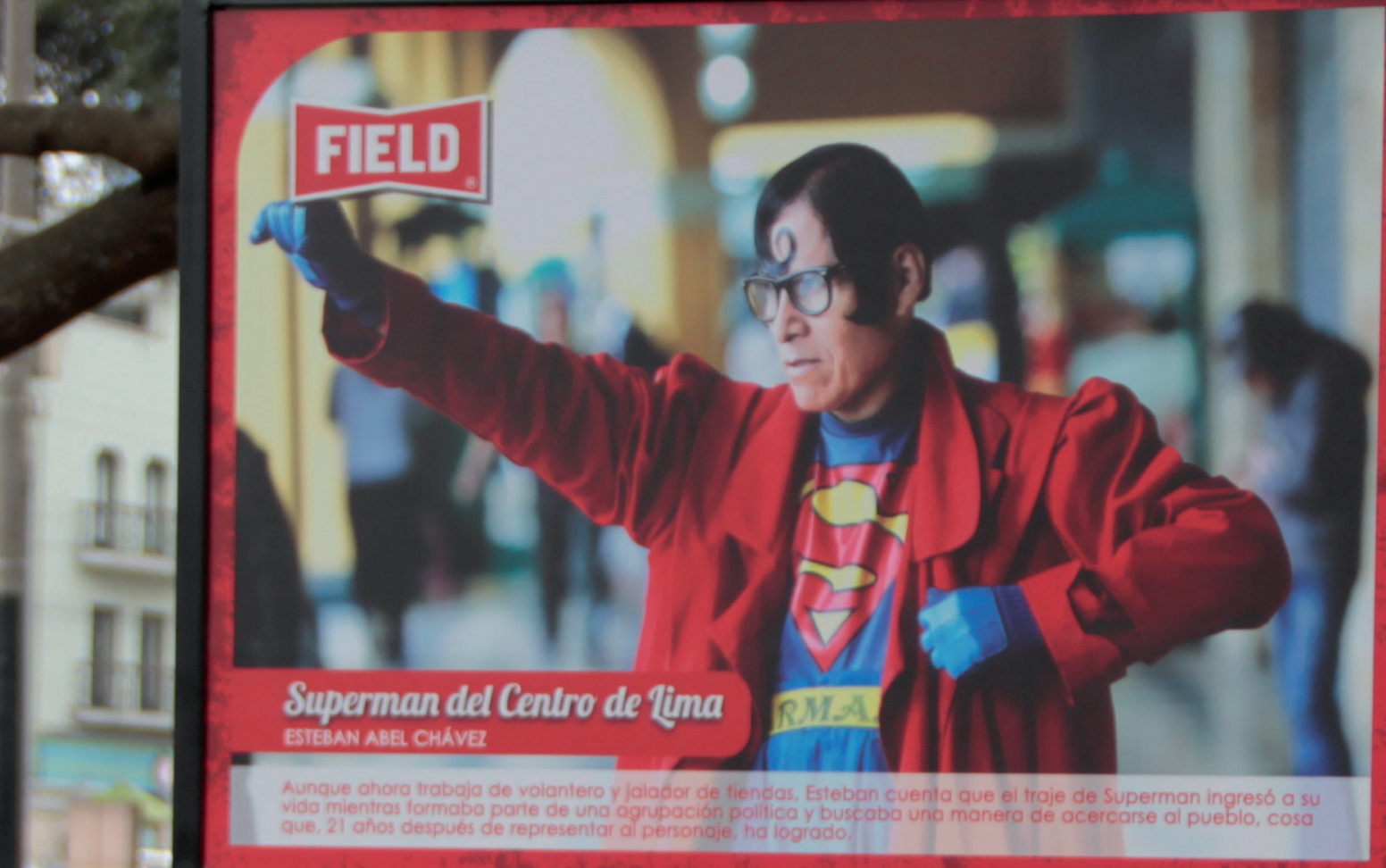

8

A

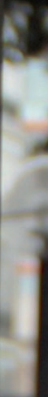

at

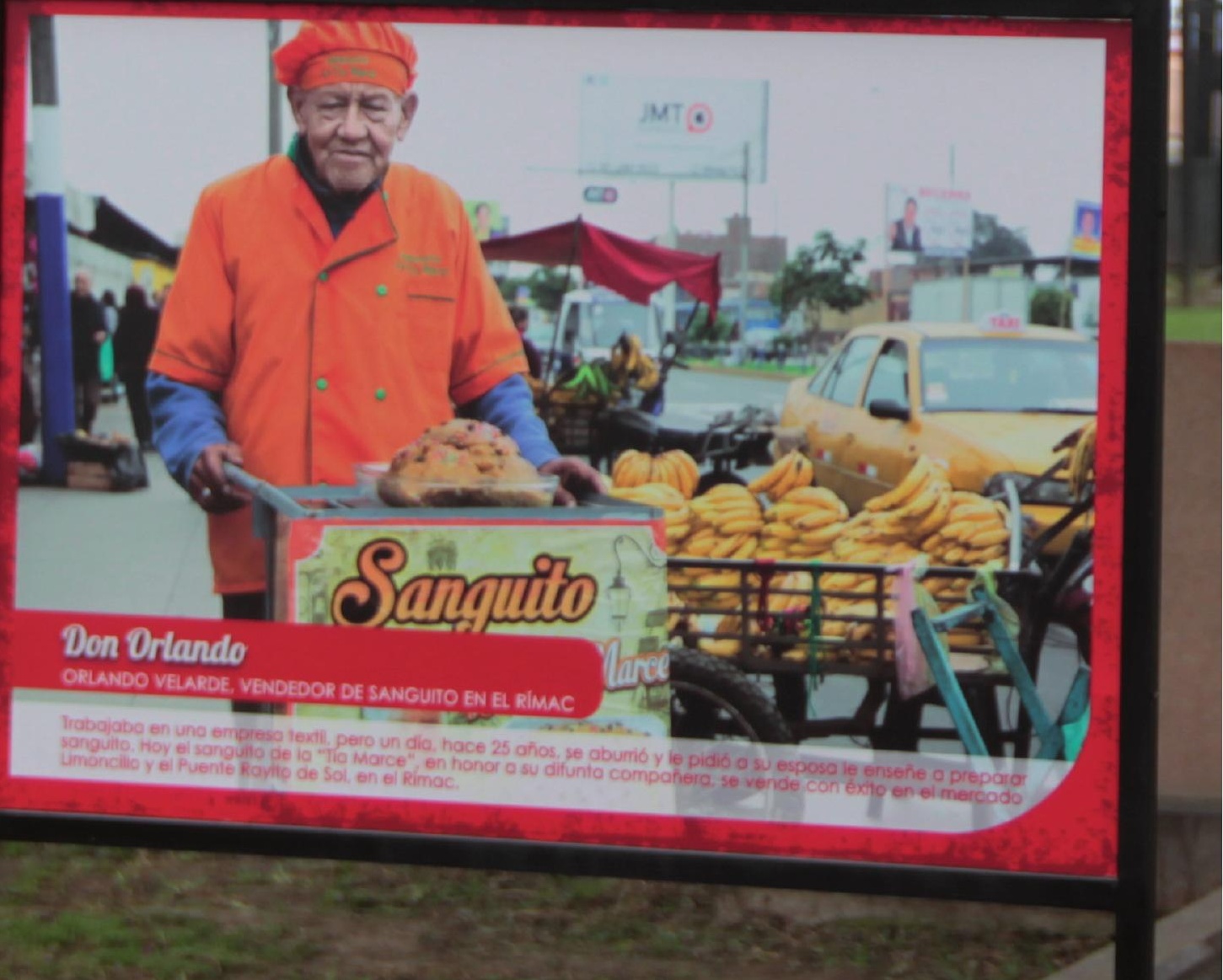




\section{Field and Its 150 Years of Memories, Longings and Feelings with All Peruvians}

The year 2014 came with a great challenge for the Field cookie and cracker brand: it was turning 150 years old and needed to recover from a sales decline from the previous year. Its response was a campaign that combined physical and digital media, which encouraged users to take action and improved the brand's sales trends. All this was achieved through appealing to the power of memories, longings and feelings that made an impact in every Peruvian's life, among which, there is, no doubt, a Field cookie bag.

\section{Context}

The Field brand, operated by Mondelēz, closed the year 2013 with a sales decline over the previous year.

On the one hand, this brand had not had any communication since 2012, when Field was relaunched as an umbrella brand for a renewed sub-brand portfolio under the campaign «Ponte filin ${ }^{1}$ ponte Field» (Feel it, feel Field).

The lack of communication of this brand during 2013 resulted in them losing affinity with and proximity to consumers. Last year, Field saltine crackers had lost participation in its penetration, recruitment, consideration, conversion and brand loyalty indicators, according to a study by Ipsos, Brand Graph Crackers-Adults (Sep. 13). Furthermore, it showed a contraction in two of its brand image axis: Equity Index and Brand Closeness, measured in this same study ${ }^{2}$.

1 Peruvian colloquialism to refer to something that generates emotions and feelings such as longing, tenderness and love. Derived from the English word feeling. 
On the other hand, in that area, the market has become more dynamic and competitive since then. The leader of the saltine cracker area showed a positive trend both in sales and on its brand image indicators operated by a strengthened portfolio in the budget brand segment. At the same time, another company with competitive brands increased media investments as of 2013 closing versus the previous year in one of its most important brands, thus strengthening its image and offer in terms of communication in the filled cookie segment.

Additionally, during the last two years, primarily in the cookie segment, new competitors entered the market with a strong support in the point of purchase and on mass media. In total, there were more than 39 innovations in the market from July 2013 to July 2014.

Although Field had relaunched two long-awaited and acclaimed products as part of its strategy in 2013: Charada Maní and Butterfield, it was also simplifying its wide sub-brand portfolio.

Amidst this, the Field local team challenged the statu quo of the categorywhich grew through innovations, high investment in mass media and promotional activities-, proposing a phygital ${ }^{3}$ campaign powerful enough to bring Field close to consumers again, reverse its sales trend and, at the same time, change the brand perception.

\section{FiEld's «Filin» Proposal}

Under this competitive environment and with the challenges mentioned, the business and communication objectives set were:

3 Phygital: a term introduced by the Momemtum Worldwide agency in 2007. This concept refers to the use of technology in such a way that it links the digital to the physical world, offering the user unique experiences by combining the offline with the online. 
Figure 1. Campaign, Communication and Business Objectives

\begin{tabular}{|c|c|c|}
\hline \multicolumn{3}{|l|}{ Campaign Objectives } \\
\hline Attribute & Sep. '13 & Objective \\
\hline It is a brand for people like me & $33.0 \%$ & $37.0 \%$ \\
\hline I trust this brand & $44.0 \%$ & $49.0 \%$ \\
\hline Peruvians feel identified with this brand & $38.0 \%$ & $45.0 \%$ \\
\hline Brand Monitor & Sep. '13 & Objective \\
\hline Attraction & $51.0 \%$ & $55.0 \%$ \\
\hline Penetration & $51.0 \%$ & $55.0 \%$ \\
\hline Consideration & $83.0 \%$ & $86.0 \%$ \\
\hline Conversion & $61.0 \%$ & $62.0 \%$ \\
\hline Loyalty & $31.0 \%$ & $32.0 \%$ \\
\hline Brand Health Indicators & Sep. '13 & Objective \\
\hline Closeness & $6.1 \%$ & $6.3 \%$ \\
\hline Brand Health Indicators & Dec. '13 & Objective \\
\hline Equity Index & $57 \%$ & $80 \%$ \\
\hline Media Reach & Objective & \\
\hline Total media reach - Target 18-49 (Source: Starcom) & $63 \%$ & \\
\hline \multicolumn{3}{|l|}{ Communication Objectives } \\
\hline Attribute & Sep. '13 & Objective \\
\hline I love its flavor & $30.0 \%$ & $38.0 \%$ \\
\hline Its packaging is practical & $32.0 \%$ & $35.0 \%$ \\
\hline It is a brand to share with friends & $31.0 \%$ & $33.0 \%$ \\
\hline \multicolumn{3}{|l|}{ Business Objectives } \\
\hline Business Objective & FY 2014 & \\
\hline Base value sales & $3.0 \%$ & \\
\hline Sales value with delisting & $2.0 \%$ & \\
\hline
\end{tabular}

In 2014, Field's main objective was to put the name of this brand on every Peruvian's mouth: through the word of mouth (making consumers talk about this brand) and the consumption of its sub-brands improving its sale levels in contrast to the previous year. 
To respond to these challenges, the team had to develop a campaign that generated both affinity with and action in consumers. In order to do this, the brand's communication axis continued to be leveraged on the concept of «Filin,» based on the following insight: «After 150 years, some brands can lose relevance and go unnoticed, just like those characters, places and situations that we see daily, but that, when we take a fresh look at them, we realize that they are much more than that because they evoke memories, longings and feelings.» This is what Field wanted to awake in their consumers, because for Field all that is «Filin.»

This is how the idea of the «150 Years of a lot of 'Filin'» came about. Field decided to celebrate its anniversary with Peruvians honoring the 150 reasons with the most «Filin» for them, evidencing and integrating them in a recognition platform that generated high affinity and closeness to the audience.

\section{THE IMPLEMENTATION}

\section{Stage 1: Collection of Reasons with «Filin»}

First of all, anonymous surveys were conducted on an audience that responded to Field's target audience about which characters, reasons and places they considered as having «Filin.» From these surveys, a list of 150 characters, 150 situations and 150 places was obtained, and this were materialized through pictures on a website that was specially designed for this campaign.

\section{Image 1. «150 Years of a lot of 'Filin'» Website}

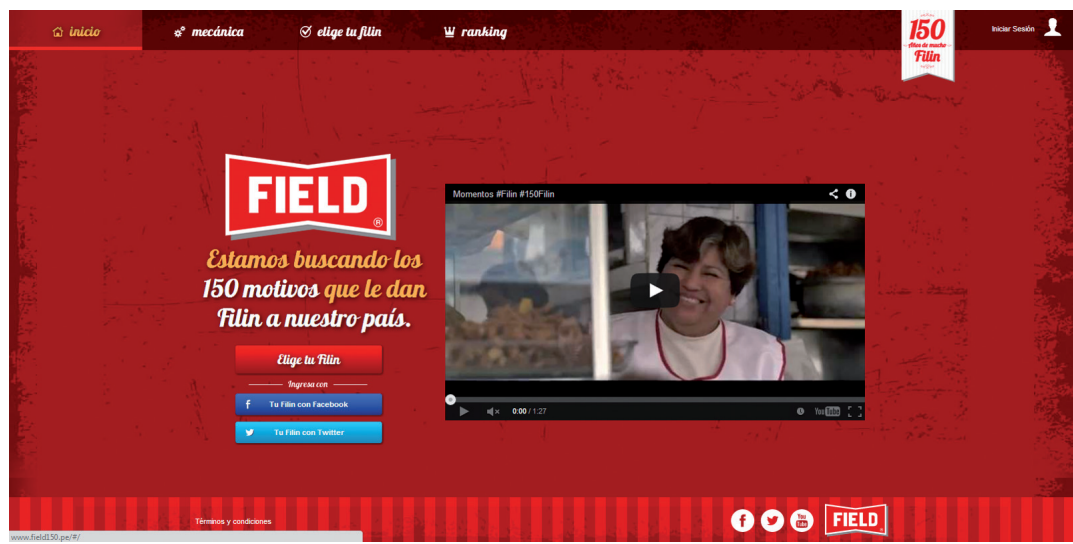




\section{Stage 2: Search for the 150 reasons That Give «Filin» to our country}

From the list of 450 reasons, they invited Peruvians to choose the 50 with the most 'filin' in every category through their votes on the website www.field150.pe, to get the 150 reasons with the most 'Filin' for Peruvians. The vote was available between August 15 and September 15, 2014. In order to participate, Peruvians had to register on the website. After registering, they could cast unlimited votes for one or more 'Filin' reasons during the campaign.

The campaign trigger was an ad especially designed to be used in digital media. It was meant to make Peruvians remember those 'filin' moments, characters or situations with joy, inviting them to celebrate Field's 150th anniversary participating in the campaign through their votes. This video also served to reactivate the brand's fan page and YouTube channel.

\section{Digital Media Spot}

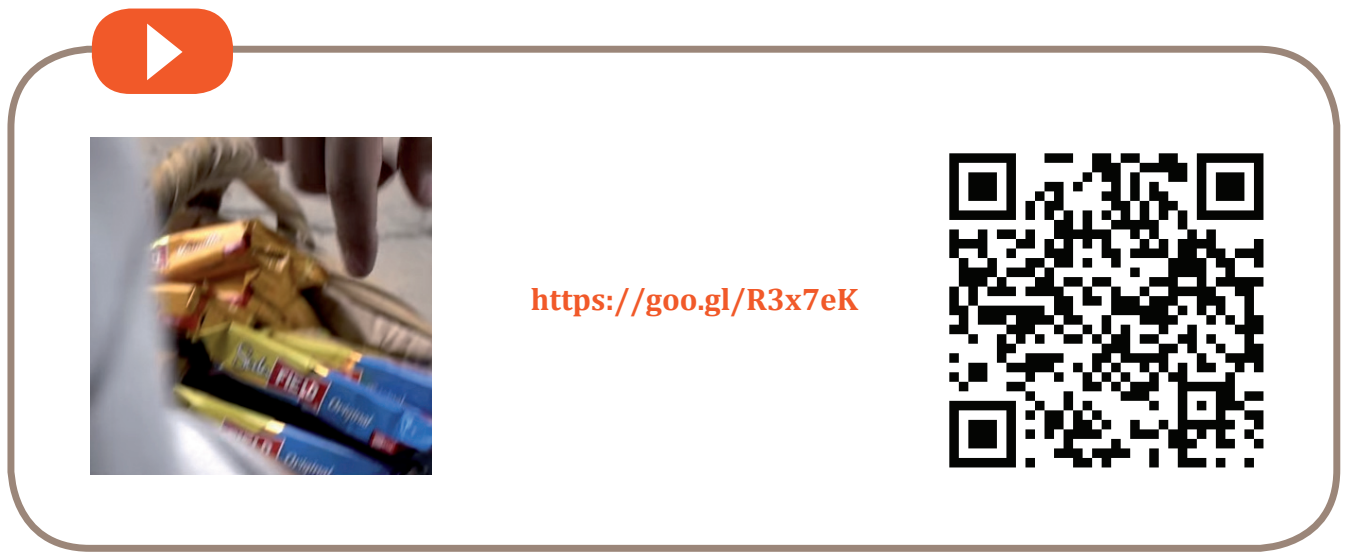

As support for the campaign, they had a range of activities that played a specific role in it:

Storytelling. The campaign had the Peruvian communicator, Luis Carlos Burneo, as an amplifier through his video blog titled «La habitación de Henry Spencer» (Henry Spencer's Bedroom) and his social media accounts: YouTube, Facebook and Twitter. Luis Carlos generated special content for the campaign, such as interviews to the characters, becoming a connecting thread between the physical and the digital. 
Note on the Video Blog «La habitación de Henry Spencer»

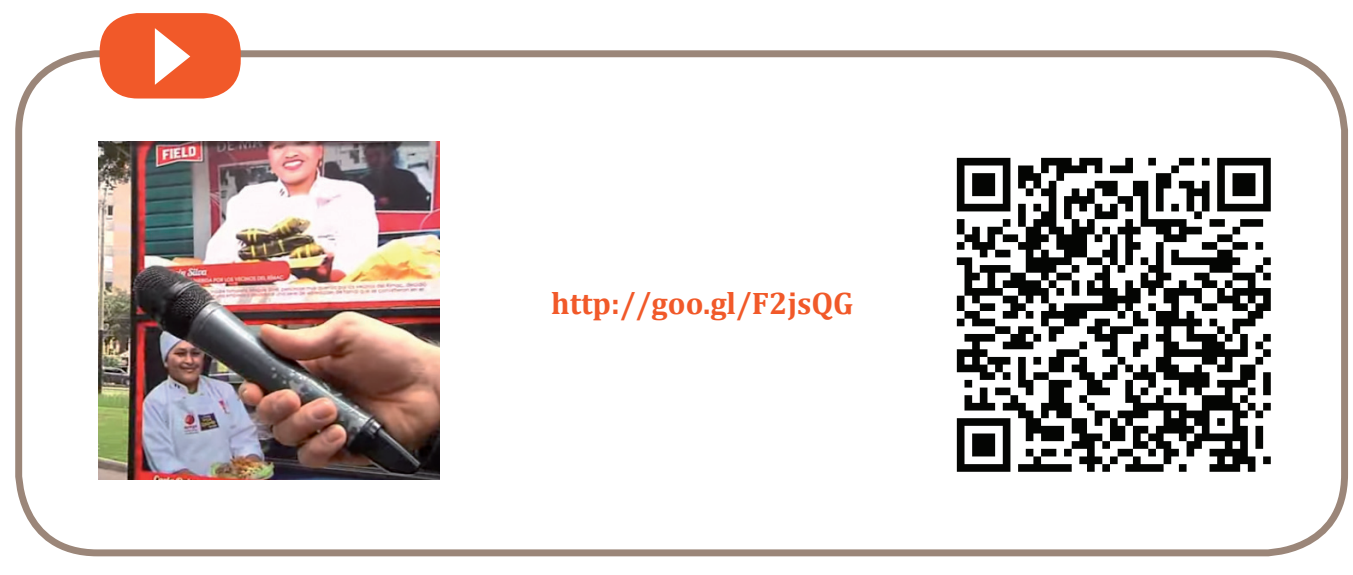

Waze. Field started using this emerging social media platform in order to generate brand awareness by showing 'filin' places in the users' routes and encouraging them to vote for them.

\section{Image 2. 'Filin' Places Highlighted on Waze}

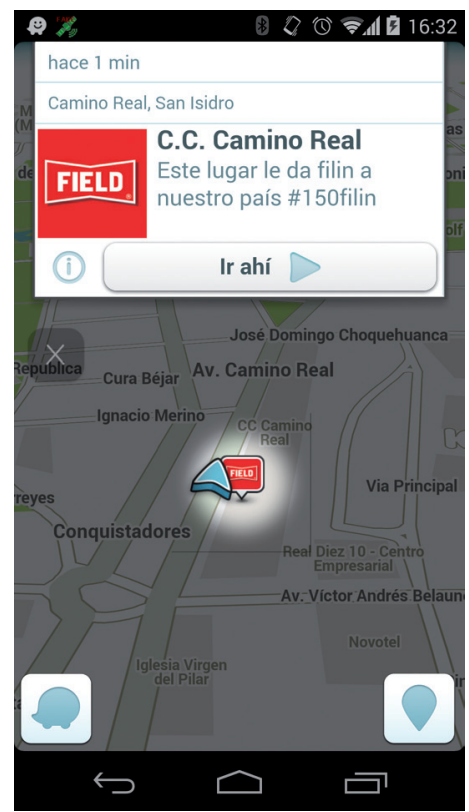


Facebook and Twitter. Field Facebook and Twitter pages had not had been active for a year. For this campaign, they created four communication and content platforms that called the consumer's attention. Thus, the campaign reached more than 13.6 million people through these specific media.

Field generated the content (the 150 reasons with most 'filin') and the Peruvians drove the campaign. A high emotional and cultural affinity and interaction with the audience was generated, all of which caused viralization on social networks. Besides, the brand was able to interact with a younger audience thanks to the collection of characters that had 'filin' for them

Some examples that evidence this mass interaction and connection between the audience and the campaign are the following:

- In the characters category, the users used the 'Perro Vaca' (Cow-Dog) fan page (with more than 30,000 followers) to vote for him. They also generated a support group for Perro Vaca within the UNMSM fan page (with more than 245,000 followers).

- Project Housing No. 3 in Cercado de Lima got together to support Mr. Juan, who received 104,449 votes.

- Fan pages of other universities also promoted the vote for their students' beloved characters.

- The audience created several memes about the campaign.

- Students took pictures with the characters' billboards and posted them on their social networks.

\section{Image 3. 'Filin' Character Taking a Picture Next to His Billboard}

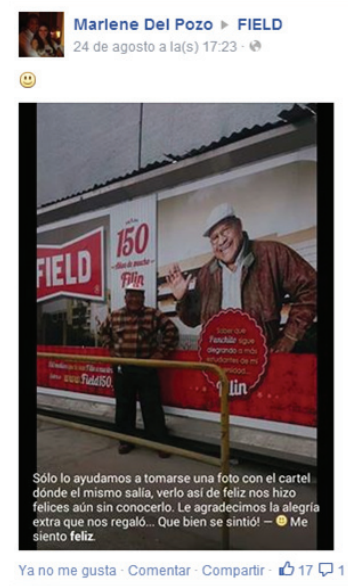




\section{Image 4. Perro Vaca, Universidad Nacional Mayor de San Marcos' Pet}

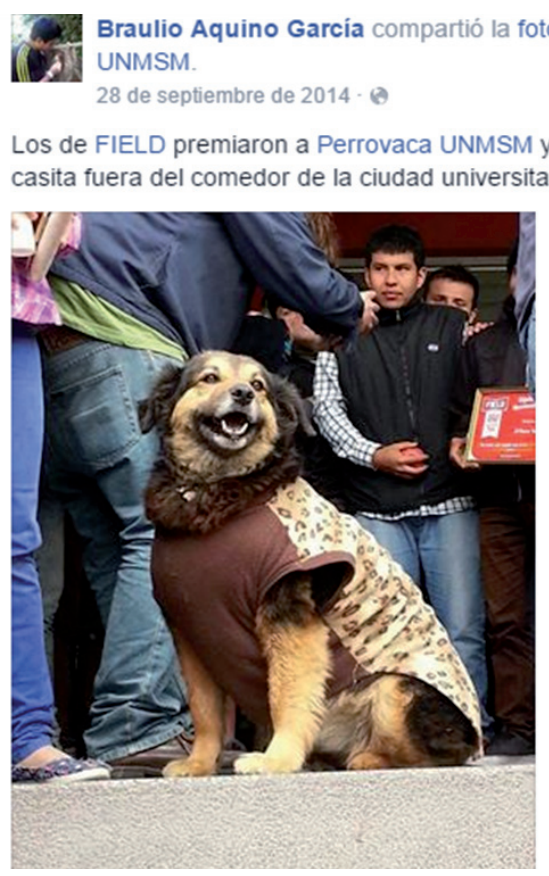

Guerrilla Marketing. Voting through activations in 'Filin' places was fostered; these places were included in the voting options. Furthermore, universities were key locations to attract a younger audience since their representative characters were participating.

Streets. This medium was used to generate campaign awareness with two reasons. On the one hand, Peruvians were invited to participate in the campaign to celebrate Field's 150th anniversary. On the other hand, some of the 'Filin' reasons were shown to promote voting on the website. 
Image 5. Example of a Billboard on the Streets

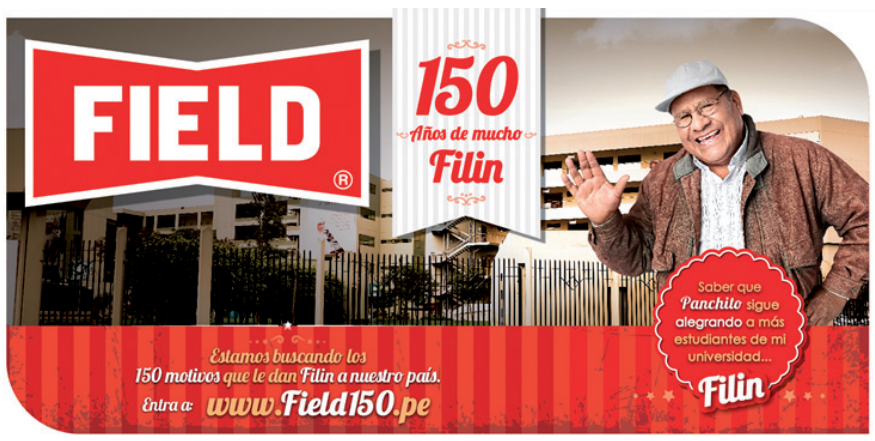

Image 6. Example of a Billboard on the Streets

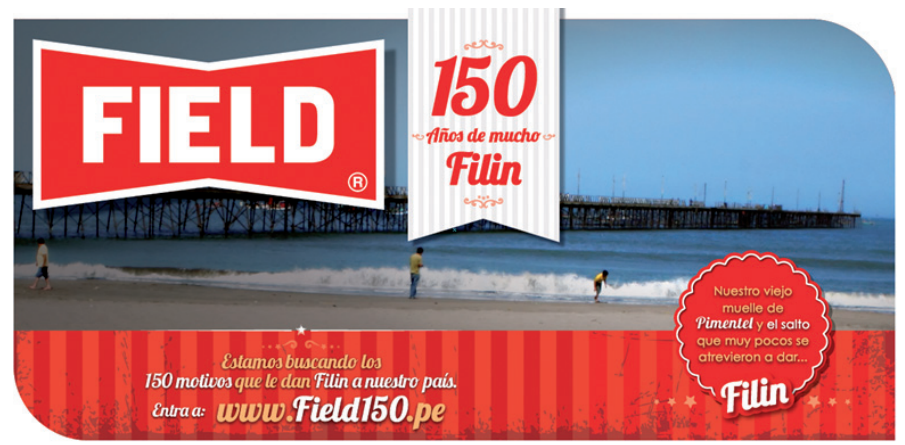

Point of Sale. Support actions were performed at the point of purchase-both in the traditional and the modern channel-with POP material to encourage Peruvians to vote for their 'Filin' reasons on the campaign website.

Endomarketing. The campaign was also integrated with an internal marketing action. Internal celebrations for Field's 150th anniversary were held in the production plant and at the administrative offices with Mondelez Peru staff. 


\section{Stage 3: Tribute to the 150 most 'Filin' Reasons}

The campaign closing was a tribute to the 150 most 'Filin' reasons chosen by Peruvians, with a photo exhibition at Kennedy Park which was open to the general public and free of charge for 3 days. The exhibition also served as a campaign amplifier, since more than 45,000 people were able to see the 150 winning reasons. Besides, the characters chosen celebrated by seeing themselves in the exhibition, which, in addition, was attended by the media who generated press releases.

With the 150 winning reasons, the brand released the first free-download e-book of a mass consumption brand. This book is available on Amazon and has a brief biography for each reason, written by the renowned blogger, Luis Carlos Burneo.

\section{Image 7. Exhibition of the 150 Reasons with Most 'Filin' at Kennedy Park}
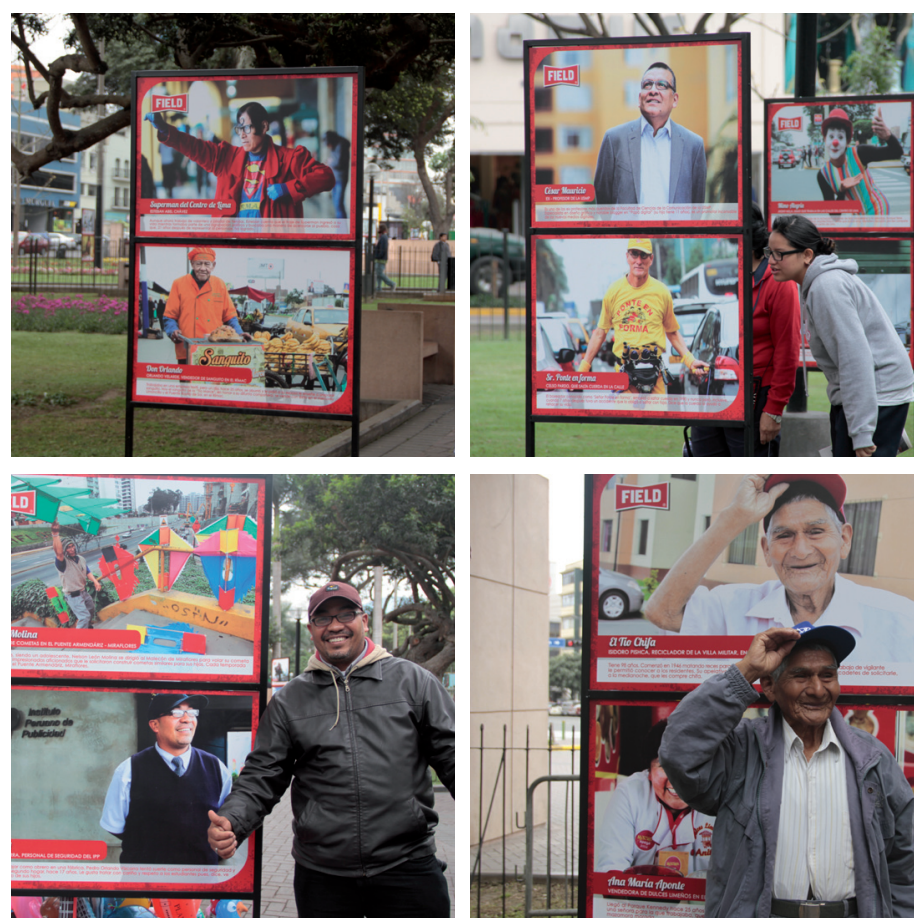


\section{«150 Reasons That Give 'Filin' to Our Country» E-book download link}

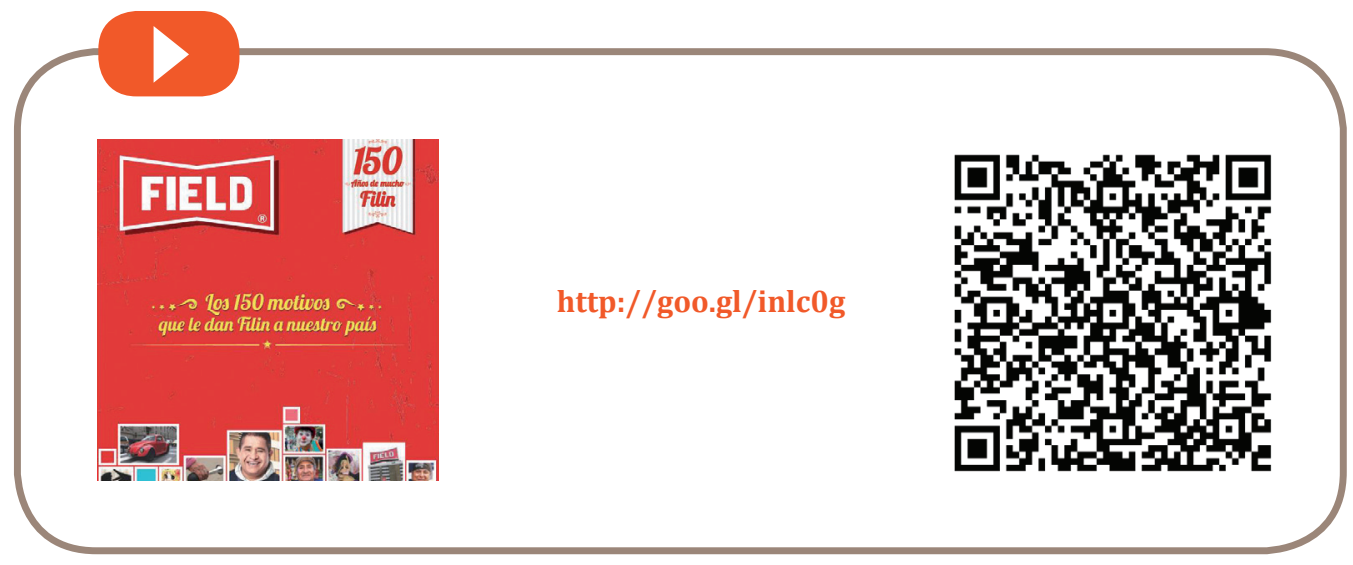

\section{RESULTS}

Field was able to innovate in this category by making a campaign that integrated the digital and the physical with a very powerful concept such as «Filin.» This is the first time that a cookie and cracker brand empowers Peruvians to co-create its content and collaborate with it, since they disclosed and decided on the winners that the brand would honor. This is a clear example of co-creation, a marketing trend today.

This campaign was able to reach millions of Peruvians without investing on television spots and it also managed to connect with thousands of consumers that participated in it. This was possible because it appealed to a real insight of Peruvians that only emblematic brands like Field can talk about: the 'Filin.'

This campaign reflected the relevance of the brand in everyday life of Peruvian families transcending beyond what a cookie may represent.

With regard to specific objectives stated at the beginning of the campaign, these were met, as can be seen in Figures 2 and 3. For instance, sales exceeded expectations with 2.3 percentage points versus what was planned. 
Figure 2. Campaign Results versus Initial Objectives

\begin{tabular}{|c|c|c|c|c|}
\hline \multicolumn{5}{|l|}{ Campaign Objectives } \\
\hline Attribute & Sep. '13 & Objective & Results & Var $\%$ \\
\hline It is a brand for people like me & $33.0 \%$ & $37.0 \%$ & $42.9 \%$ & $5.9 \%$ \\
\hline I trust this brand & $44.0 \%$ & $49.0 \%$ & $51.0 \%$ & $2.0 \%$ \\
\hline Peruvians feel identified with this brand & $38.0 \%$ & $45.0 \%$ & $51.1 \%$ & $6.1 \%$ \\
\hline Brand Monitor & Sep. '13 & Objective & Results & Var \% \\
\hline Attraction & $51.0 \%$ & $55.0 \%$ & $56.0 \%$ & $1.0 \%$ \\
\hline Penetration & $51.0 \%$ & $55.0 \%$ & $56.0 \%$ & $1.0 \%$ \\
\hline Consideration & $83.0 \%$ & $86.0 \%$ & $92.0 \%$ & $6.0 \%$ \\
\hline Conversion & $61.0 \%$ & $62.0 \%$ & $61.0 \%$ & $-1.0 \%$ \\
\hline Loyalty & $31.0 \%$ & $32.0 \%$ & $34.0 \%$ & $2.0 \%$ \\
\hline Brand Health Indicators & Sep. '13 & Objective & Results & Var \% \\
\hline Closeness & $6.1 \%$ & $6.3 \%$ & $6.3 \%$ & $0.0 \%$ \\
\hline Brand Health Indicators & Dec. '13 & Objective & Results & Var \% \\
\hline Equity Index & $57 \%$ & $80 \%$ & $80 \%$ & $0.0 \%$ \\
\hline Media Reach & Objective & & Results & Var $\%$ \\
\hline Total media reach & $63 \%$ & & $76 \%$ & $13.4 \%$ \\
\hline \multicolumn{5}{|l|}{ Communication Objectives } \\
\hline Attribute & Sep. '13 & Objective & Results & Var \% \\
\hline I love its flavor & $30.0 \%$ & $38.0 \%$ & $42.6 \%$ & $4.6 \%$ \\
\hline Its packaging is practical & $32.0 \%$ & $35.0 \%$ & $42.0 \%$ & $7.0 \%$ \\
\hline It is a brand to share with friends & $31.0 \%$ & $33.0 \%$ & $40.4 \%$ & $7.4 \%$ \\
\hline \multicolumn{5}{|l|}{ Business Objectives } \\
\hline Business Objective & FY 2014 Obj & & Results & Var \% \\
\hline Base value sales & $3.0 \%$ & & $5.3 \%$ & $2.3 \%$ \\
\hline Sales value with delisting & $2.0 \%$ & & $3.2 \%$ & $1.2 \%$ \\
\hline
\end{tabular}

Source: Ipsos Brand Graph Crackers - Adults Oct. 2014 
Figure 3. Results of Digital Media Campaign versus the Objectives

\begin{tabular}{|c|c|c|c|}
\hline \multicolumn{4}{|c|}{ Digital Objectives - Web Platform } \\
\hline KPIs & Objective & Results & Variation \\
\hline Website visits & $\begin{array}{l}<80,000- \\
100,000>\end{array}$ & 149,000 & $49.0 \%$ \\
\hline Length of stay & 3:00 min & $3: 20 \mathrm{~min}$ & $6.7 \%$ \\
\hline$\%$ of bounce & $40 \%$ & $40 \%$ & $0.0 \%$ \\
\hline \# of votes & 500,000 & $1,067,821$ & $113.6 \%$ \\
\hline \multicolumn{4}{|c|}{ Digital Objectives - Facebook Social Media Channel } \\
\hline KPIs & Objective & Results & Variation \\
\hline Engagement / People talking about & $<0.5 \%-1.0 \%>$ & $10 \%$ & $900.0 \%$ \\
\hline Fan incremental & $\begin{array}{l}<80,000- \\
100,000>\end{array}$ & 9352 & $0.0 \%$ \\
\hline Posts likes & $<100-1,000>$ & 5,746 & $474.6 \%$ \\
\hline Shares & $<20-50>$ & 603 & $1106.0 \%$ \\
\hline Comments & $<50-150>$ & 608 & $305.3 \%$ \\
\hline Impressions & 539700 & $3,539,700$ & $1078.9 \%$ \\
\hline \multicolumn{4}{|c|}{ Digital Objectives - Twitter Social Media Channel } \\
\hline KPIs & Objective & Results & Variation \\
\hline New followers & $<1000-1200>$ & 1,301 & $8.4 \%$ \\
\hline Mentions & $<35-65>$ & 70 & $7.7 \%$ \\
\hline RT & $<35-65>$ & 68 & $4.6 \%$ \\
\hline Hashtag reach & $1,000,000$ users & $1,330,894$ users & $33.1 \%$ \\
\hline Hashtag impressions & $1,200,000$ views & $1,534,109$ views & $27.8 \%$ \\
\hline
\end{tabular}

Additionally, a significant return was obtained in media investment thanks to the actions given that 30 unpaid press impacts were generated, which equaled more than USD 90,000. These impacts appeared in newspapers, magazines, digital media and TV programs. 
Finally, the campaign exceeded its commercial expectations. Field stopped its negative sales trend and obtained a 5.3\% invoice growth versus 2013 in its portfolio. Furthermore, it significantly improved the main brand health indicators of Field Soda (saltine crackers) and broke participation records with more than one million votes, a $+10 \%$ engagement rate and a more than 8 million Peruvians reach without resorting to television.

Without a doubt, it is a clear example of the perfect combination of a powerful insight such as 'Filin', linked to digital media, which bears evident 'filin' among both digital natives and all those who are not, because the world is heading unstoppably that way. Finally, the third element, the consumer and brand followers' participation, which is the foundation of the co-creation, where consumers feel «part of» and participate with a feeling of transcendence in the process and in the communication: a success.

\section{Opinion}

An action's success is measured by its results: almost doubling the expected sales target, reaching 8 million Peruvians, generating a USD 94,000 PR value, all are very positive indicators considering that television was not used. In addition,, consumer's participation was essential and well thought-out to collect information about people with 'filin', who represent many Peruvians. Having a campaign that brings back memories, longing and feelings of more than 150 years is very impressive. However, it is even more impressive that it was channeled mainly through digital media, considering the reason. Without any doubt, it shows how marketing as well as consumers are changing, .

James Leigh

Administration and Marketing Program Director at UPC 


\section{D’Onofrio's Panettone Campaign: «Regala la magia de la Navidad peruana»}

Company:

Nestlé Perú S. A.

Agency:

Métrica Comunicación

Category:

Public Relations 


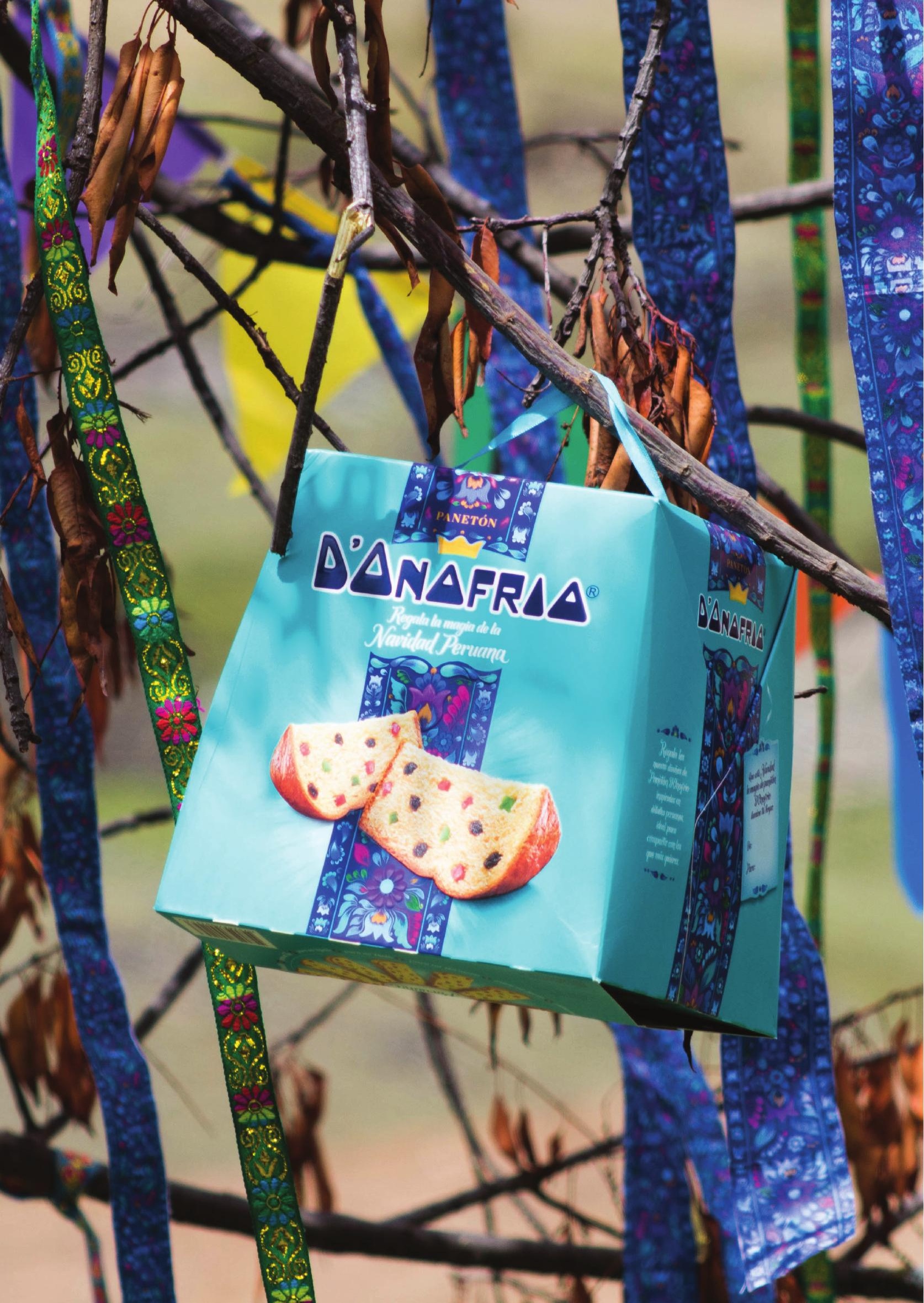




\section{Marketing 3.0 in search of the consumer and society's well-being}

D'Onofrio's Panettone is continually striving to keep its promise of bringing the magic of Christmas to all Peruvians In 2015, the brand's team came up with the idea of light as a Christmas symbol. However, they were aware that in some places of the country people still did not have access to electricity. In spite of this, the brand was able to arrive to Acchahuata, Cusco, a village whose nearest light point was $10.5 \mathrm{mi}$ away. This campaign is an example of a public relations plan that is coherent with the brand's marketing and social responsibility objectives.

\section{BACKGROUND}

Due to the brand's work in previous years, both consumers and public opinion were very interested in knowing what D'Onofrio would present for the Christmas season. Hence, the 2014 Christmas campaign represented a very challenging and particularly demanding one. With the arrival of new entrants to the market, D'Onofrio had the responsibility to keep spreading the added value of their products, as well as their strong loyalty to the brand.

It is important to remember that in 2012, the brand decided to give an extraordinary experience to a community in need. Thus, the world's first boat cinema was built in the town of Belén, Iquitos, where the kids were able to see a movie for the first time, seated on their traditional canoes. Later on, in 2013, the brand identified and shared with public opinion some of the most traditional Christmas celebrations in every corner of our country, an idea that was accomplished through anthropological work. 


\section{The Proposal}

The brand knew they had to keep revaluing Peruvian customs and traditions, taking the message to all Peruvians during Christmas time.

This time, they wanted to make something different, something that would be sustainable in time and would turn the brand into a real agent of change.

To that end, for the 2014 campaign D'Onofrio identified different vulnerable villages where they could make a radical change and finally chose Acchahuata, in Cusco as the ideal town to do something without precedents and enduring in time. Some of the actions taken included using solar panels, audio and video equipment, training, hiring specialists in rural communities, among others.

As part of their marketing strategy of bringing the magic of Peruvian Christmas, the brand wanted to change their traditional packaging. They wanted their product to highlight Peruvian traditions even more. Therefore, after several studies conducted during the year, they chose the Ayacuchan 'retablo' as a great way of revaluing Peruvian identity and, inspired on the traditional cintillos, they finally launched their new package.

The Public Relations and External Communications Plan set three goals for the D’Onofrio's Panettone campaign, «Regala la magia de la Navidad peruana» (Give Away the Magic of Peruvian Christmas):

1. To disseminate D'Onofrio's Panettone presence and business situation in the Peruvian market through mass media, as well as the constant innovation of their products.

2. To disseminate in mass media in Lima and provinces, D'Onofrio's initiative of providing electricity through solar panels to the village of Acchahuata, in Cusco.

3. To position D'Onofrio's Panettone as the leading brand in its category, not only for the products' innovation, but also for their creativity when developing such a huge campaign.

\section{The Implementation}

In order to reach the proposed plans and knowing that the initiative had different communication elements simultaneously, Nestlé Perú and its public relations agency Métrica Comunicación, decided for a plan to be developed in four areas over a period of more than six months: 


\section{Immersion: from July to November}

In this phase, the main task was to select the relevant and basic information for the campaign. To this end, several teams with different specialties were put together: digital, creative and public relations specialists, media agencies, among others. From the beginning, teamwork was essential for achieving this objective. During this phase, the necessary press documents were prepared for every single appearance of the brand's spokesmen during the campaign, such as key messages, memory helping tools, press releases (of the business and campaign), press kit lists, spokesmen training and FAQs.

\section{Communication about the Sector: November}

In this phase, the mission was to disseminate the current business situation in the Peruvian market through the main mass media.

Due to the brand's relevance, the product consumption scope during the holidays and the press interest, D'Onofrio gave a press conference in Lima with four key mass media: El Comercio, Gestión and Publimetro newspapers, and RPP TV channel.

This way, the brand's target audiences were addressed and the messages were spread both accurately and coordinately . Prior to this, a comprehensive media training was held for the spokesperson to be correctly prepared.

Anticipating the fact that mass media do not attend such type of interviews with photographers, a previous photo session was made in order to have a professional photo file of the spokesperson with the products. A special photo file was built for each media, according to their style and characteristics and protecting the exclusivity of the photos delivered. The result? All the journalists that interviewed the spokesperson used the photos they received, maximizing the brand's presence in each media. Just in this phase, the brand reached 31 impacts and 3 journal covers, estimated at USD 218,998.95. 


\section{Image 1. Example of Press Impact Generated by Press Conference}

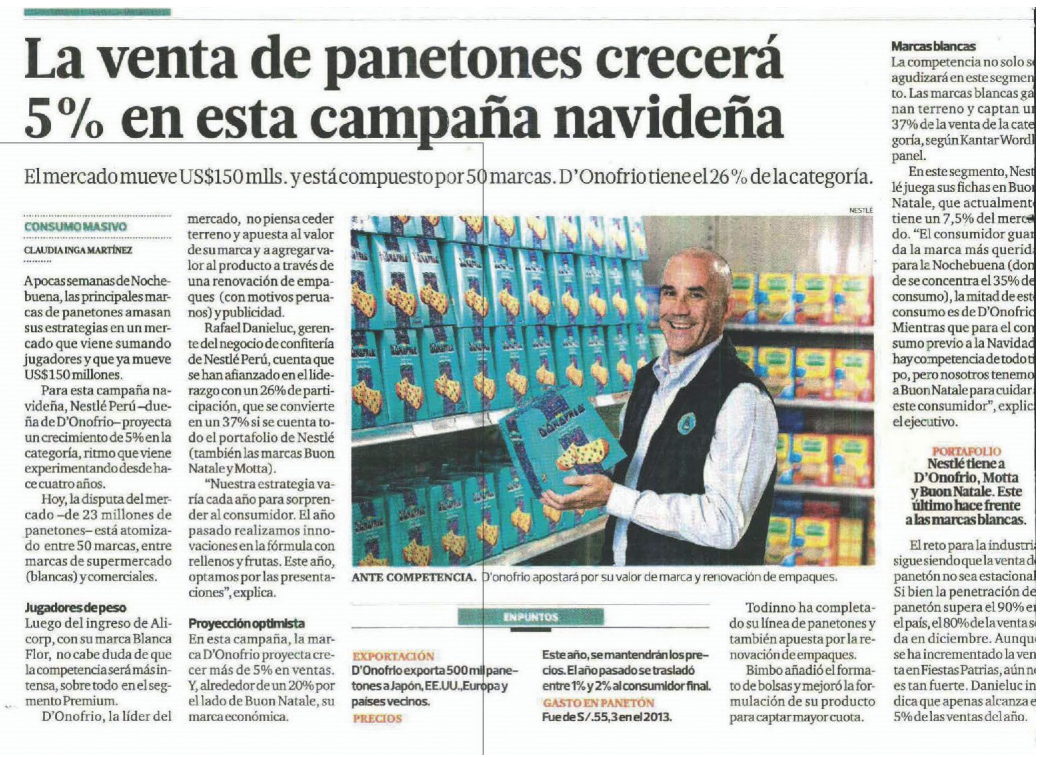

The same day of the press conference, D'Onofrio launched a massive press release emphasizing the following:

- The brand's leadership in the local market

- The figures on panettone consumption in Peru

- The campaign's consumption expectations

- The packaging's new image

- Some information about the work to be done in Acchahuata, Cusco

The news story had 2 photos: one of the Nestlé Peru confectionery manager along with the brand's spokesperson, and another of the new packaging. At the same time, journalists and key opinion leaders were identified, in order to give them a box of D'Onofrio's Panettone with the season's new packaging.

Also, some communication actions were coordinated to bring out the work of Gabriel Ataucusi, an Ayacuchan retablo handcrafter who took part in the brand's new box design. For instance, the brand obtained an exclusive interview with Caretas magazine managing to get a full-page coverage. 


\section{Image 2. Press Impact on Retablo Handcrafter}

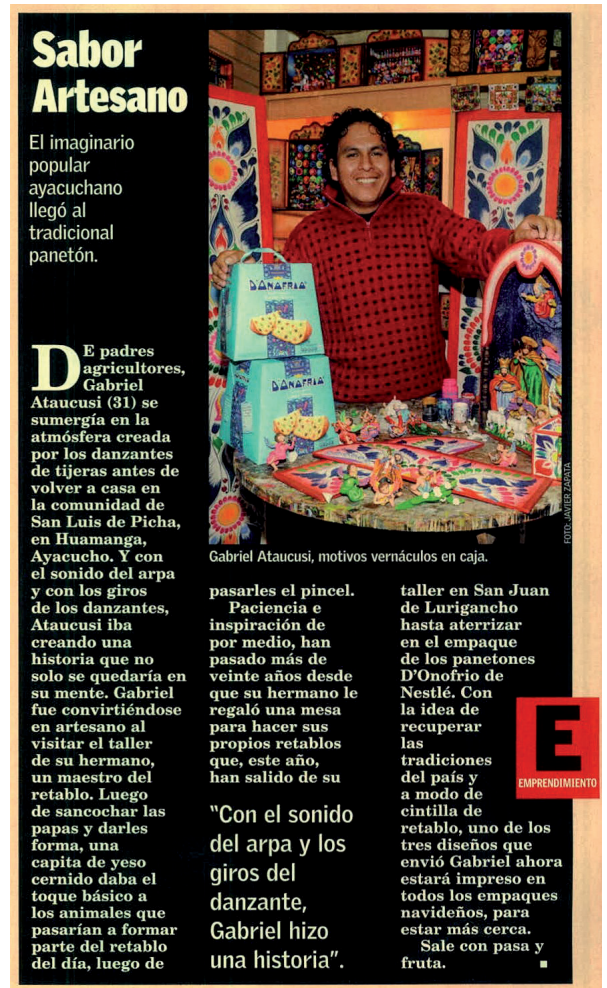

\section{Tour across the Country: December}

Taking the results of the brand's previous experiences into account, the brand made a media tour across the main cities of Peru.

Both the company and the agency selected five key cities according to their business relevance and media quality. The cities chosen were the following: Arequipa, Cusco, Huancayo, Trujillo and Chiclayo. The tour's goal was to notify the media about the work done in Acchahuata, Cusco, and to show the brand's new packaging.

However, they needed a previous announcement. The brand wouldn't reach the provinces' media attention only with the campaign and the new packaging news. Therefore, they needed to do something that generated media interest. On this account, the brand established a partnership with Real Plaza, Peru's largest shopping mall chain, so that they would take part in their Christmas celebrations all over the country 
by giving away D'Onofrio's Panettones to all the families in attendance.

With the resources in hand and in coordination with Real Plaza's calendar activities, the brand later planned a media tour in the cities chosen .

For two days, they paid a visit to all the main communication media of each city. In each medium, families were invited to Real Plaza's events, the Acchahuata campaign was mentioned, and the brand's new packaging was discussed.

Two spokesmen were chosen for the tour, since they had to visit five cities in a very short time. Thus, after a media training the brand managed to visit five cities in just two weeks. It was very important for the brand to complete this tour in two weeks, since it was the period in which the business generated the highest sales of the year.

At the same time and taking into account the provinces' media interest thanks to the images showing its social support, D'Onofrio presented the Acchahuata's campaign commercial and photos. The media reception was very positive and all TV channels showed the commercial images while interviews were being held.

\section{TV Spot}

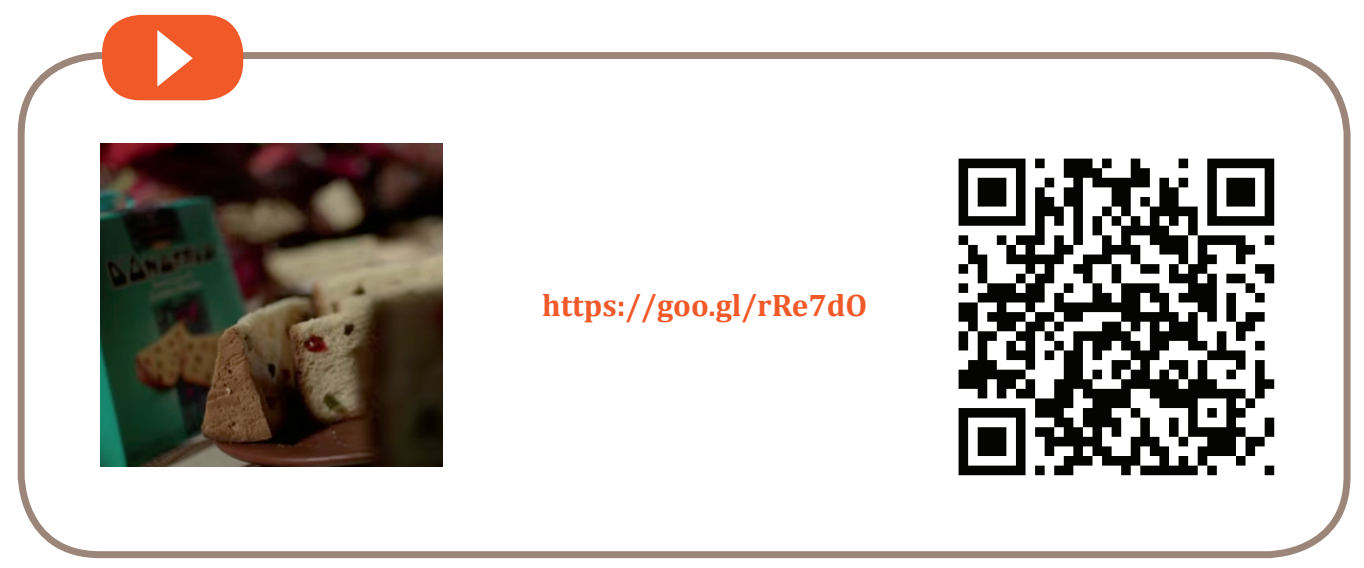




\section{Trip: October to December}

An important part of the campaign was to take, exclusively, one print media and one TV channel to Acchahuata to witness the impact that the brand was reaching in the village by providing electricity that Christmas.

To this end, an interesting itinerary was scheduled for them, since it was not only important that they could see the campaign's efforts, but also that they could listen to some moving life stories and other interesting information.

Therefore, the campaign team traveled twice to the village in search of a story that would persuade these mass media to go there. As a result, some life stories were identified and a specific itinerary was scheduled. The team also considered important that the electricity they were providing be used by the villagers, which meant a challenge since they were not used to this resource.

Hence, the brand hired a team of specialists in rural communities to develop activities that would teach them how to make the most of the new resource D'Onofrio's Panettone was bringing them.

With all this information, the two mass media chosen were invited to be part of this great adventure. On the one hand, they wanted to choose a TV channel that could take advantage of everything they were going to get to know and could give the brand the opportunity to tell this story. Taking this into account, they decided to offer the exclusive to the Sunday TV program Punto Final, of Frecuencia Latina channel.

On the other hand, they wanted to choose a formal national newspaper that could show how impressive the campaign was through its photos and narrative style. Therefore, they decided to offer the information to the «Regiones» section of $E l$ Comercio newspaper

A three day itinerary was planned for both media. The Sunday before Christmas, Punto Final issued a 14-minute report, coincidentally during prime time. 
Figure 1. Rating of Sunday, December 21, 2014

\begin{tabular}{|c|c|c|c|c|c|c|}
\hline Start & \multicolumn{1}{c}{ End } & Program & Total & AB & \multicolumn{1}{c|}{ C } & DE \\
\hline $\begin{array}{c}\text { 10:30 } \\
\text { p.m. }\end{array}$ & $\begin{array}{c}10: 59 \\
\text { p.m. }\end{array}$ & $\begin{array}{c}\text { (A) Punto } \\
\text { final }\end{array}$ & 10.6 & 11.8 & 12.8 & 7.6 \\
\hline
\end{tabular}

Source: Ibope Media

«La magia de la luz» (The Magic of Light) News Report in Punto Final

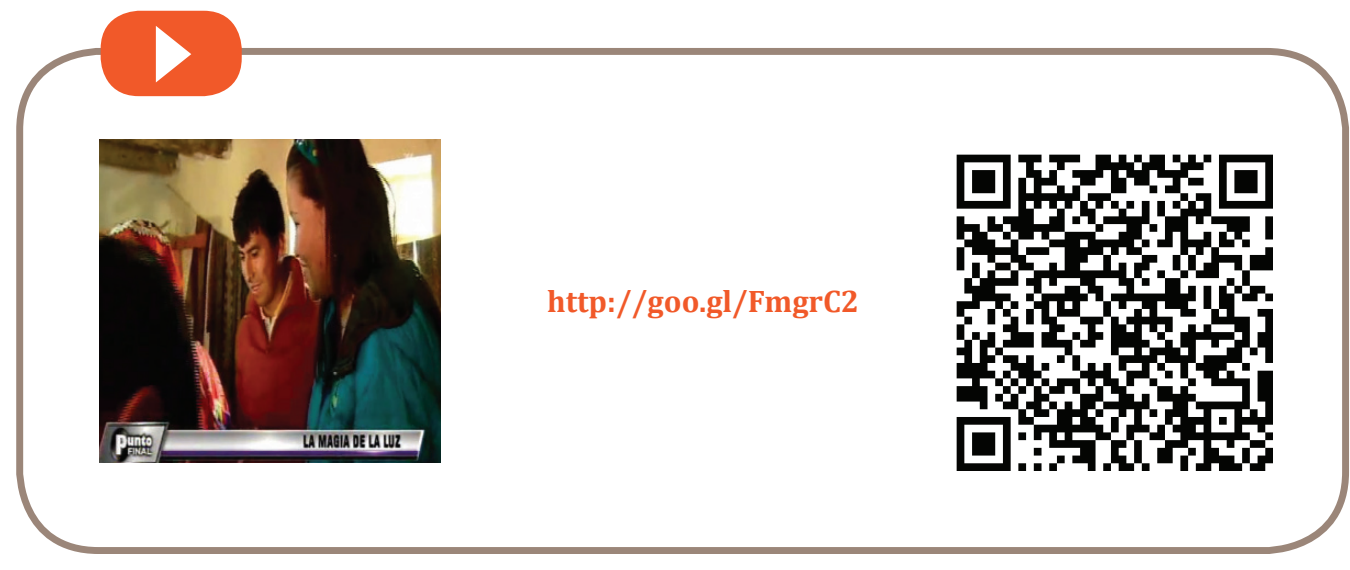

Additionally, that same Sunday, El Comercio published the news story and the brand managed to appear on that edition's cover, all of which tripled its sales. 
Image 3. Article and Cover Mention in El Comercio

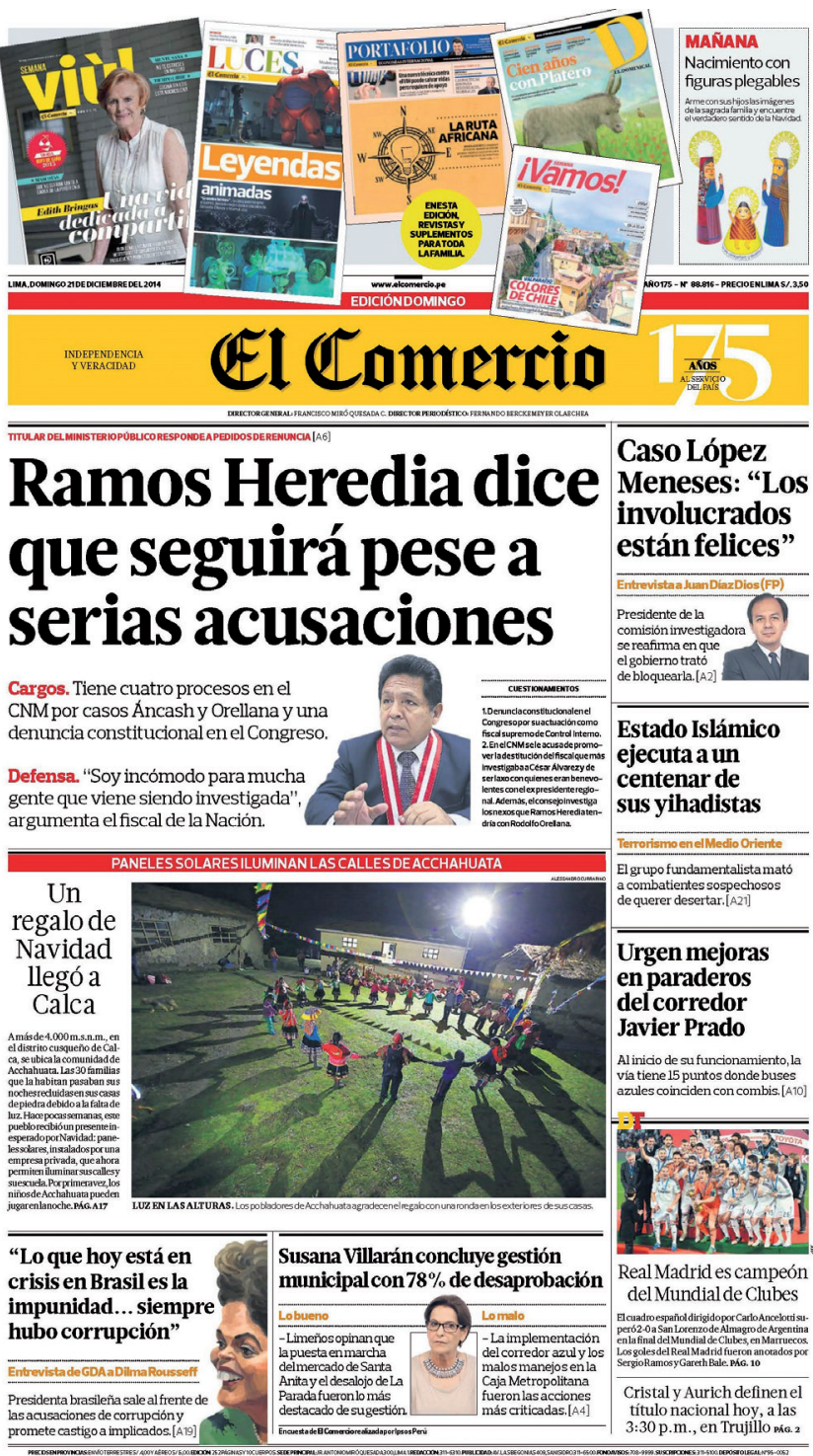


During the media's trip to Acchahuata, D’Onofrio's Panettone creative agency recorded a viral video in that village, highlighting some life stories. With this 2-minute material, the brand made an additional news story targeted at the digital media, highlighting the campaign's success.

\section{Viral Video for the Digital Campaign}

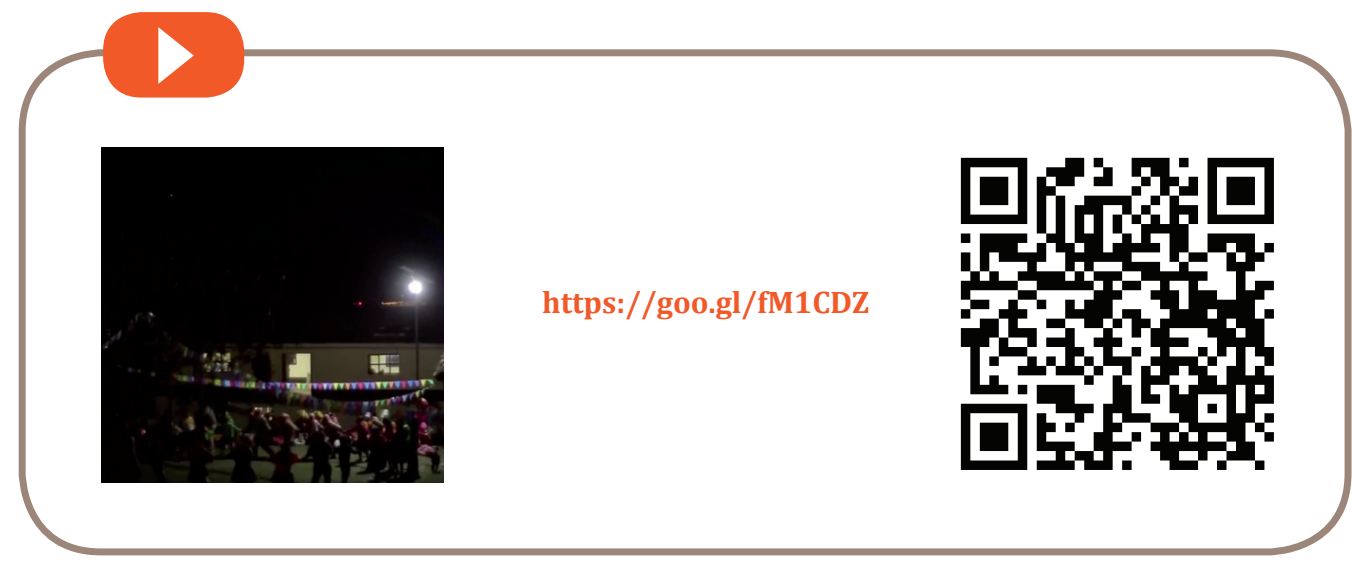

Example of a Viral Video Used in a Digital Medium

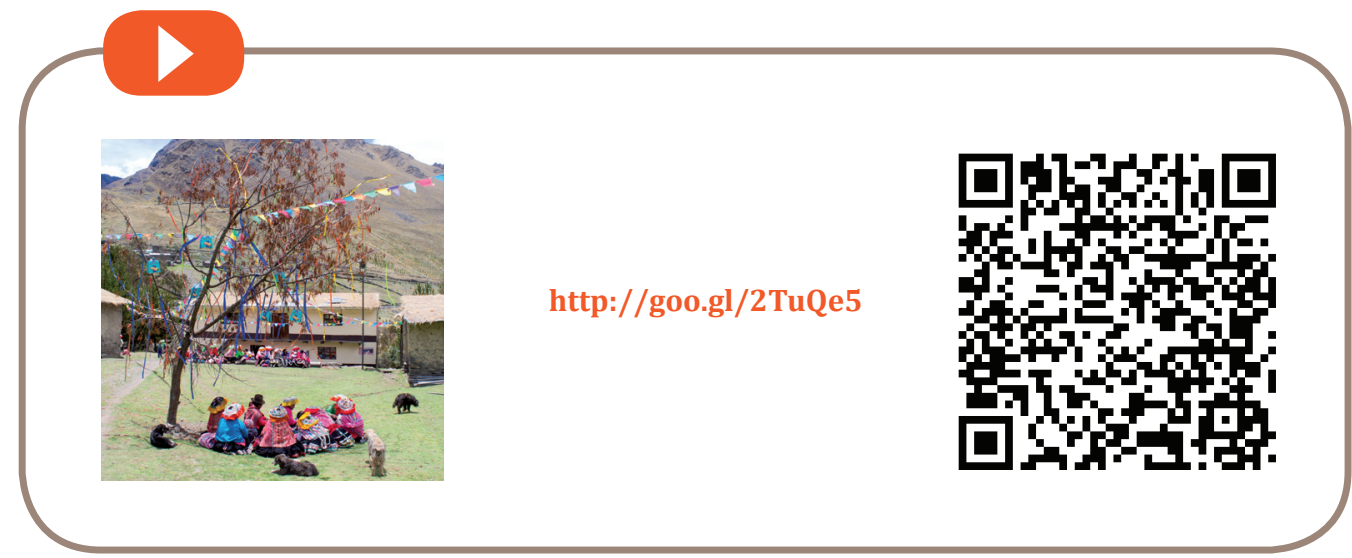


Finally, the department of Corporate Affairs and External Communication decided to hire the Ayacuchan retablo handcrafter Gabriel Ataucusi, creator of the brand's new image so as to direct the manufacture of 100 Ayacuchan loom pieces to share the story of D'Onofrio's Panettone with the country's 100 most influential opinion leaders.

\section{RESULTS}

As for the media broadcasting purpose, the initial goals were largely met. Thanks to this campaign, the brand reached 97 impacts, estimated at a total of USD 1,266,780.34.

Of these 97 impacts, 41 corresponded to Lima, estimated at USD 1,046,629.64. On the other hand, the brand reached 56 impacts in the cities of Chiclayo, Huancayo, Cusco, Arequipa and Trujillo, estimated at a total of USD 220,150.70.

As for the brand's market share, D'Onofrio's Panettone grew $+5.4 \%$ in value, while the total market grew $+1.2 \%$. This caused a positive impact of 90 base points in the valued market share, going from $23.8 \%$ to $24.7 \%$. The brand also obtained a $20 \%$ return on the investment in advertising.

D'Onofrio's Panettone sales also grew 5.4\%, which was more than expected, taking into account that the panettone market only grew $1.2 \%$ in that same period of time.

As for the third goal set at the beginning of the campaign—to position D'Onofrio's Panettone as the leading brand in its category, not only for the innovation of their products, but also for their creativity in developing such a campaign-, the brand had the following achievements: all stakeholders recognized, valued and commented on the initiative of D'Onofrio's Panettone in Acchahuata. Also, and thanks to the delivery of 100 kits to the country's main opinion leaders, they believed in and highlighted the importance of this activity and its endurance in time. Additionally, consumers saw in D'Onofrio's Panettone a brand that is committed to society, that always highlights Peruvian identity and that is constantly innovating. 


\section{External and Internal Participation Levels}

From the beginning of this project, the marketing management of D'Onofrio's Panettone called upon all the agencies involved to be part of this initiative. Publicists, creative and public relations specialists, among others were present from the very first ideas in order to build up an effective plan of action.

Once the strategy was defined, a group of specialists in rural communities was hired so as to teach and train people on how to develop and make the most of the new resource.

Finally, taking into account the training workshops, the installation of plant nurseries, the implementation of loom areas, play areas in schools, etc., an internal fund-raising campaign was organized, involving the different departments and businesses of Nestlé Perú, so they were able to make donations that would strengthen the work started by D'Onofrio's Panettone, adding to the company's commitment to this project.

\section{Contribution to Society and Consumers}

Through this campaign, D'Onofrio's Panettone has been able to contribute to the country's integration. Arriving to Acchahuata, Cusco to train the community in the use of electricity, has helped the community to organize better, creating responsibilities for each member and turning their village into a better place to live in. It is also worth mentioning that the campaign was decentralized, which allowed showing different realities, broadening the message of Christmas.

Hence, inclusion was crucial. The goal was for all the people involved to take part in and witness the magic of the Peruvian Christmas brought by D'Onofrio's Panettone.

The campaign also contributed to the preservation of the environment. To this end, specialists in rural communities were hired so as to run a workshop where all the community of Acchahuata developed awareness regarding the preservation of the environment through games and seminars. Kids, for instance, learned how to be careful with their waste. They were also trained on the correct use and disposal of batteries.

Moreover, the installation of solar panels favored the use of solar energy and the organic gardens created by the brand has helped the community to become more aware of land use.

In conclusion, this was a very modern campaign because, unlike previous years, 
the brand opted for a sustainable action in time that provided them solid information to share. Therefore, they decided to make something permanent for the village.

Also, hiring specialists in rural communities was key to identifying the people's needs and to train them in the use of electricity. Likewise, hiring a Quechua interpreter was also necessary to communicate with them.

It should also be noted that no other Nestlé Perú campaign has prepared a separate file of professional photos for each media that interviewed the brand's spokesperson in Lima.

One of the conditions for a company or brand to opt for marketing 3.0 is that it has to be driven out of conviction and not out of obligation. This campaign shows the conviction of both Nestlé and D'Onofrio's Panettone on the consumer and society's welfare in the long term. Social responsibility, environmental preservation, sustainable development and an improvement in the quality of life are all elements that emerge from this strategy and its results, which are an example to be followed by other brands.

\section{Opinion}

Besides being an example of marketing 3.0, this campaign is also the best example of how stakeholders' management and the commitment of each of Nestlé collaborators made this successful campaign possible. In order for the campaign to be decentralized, the brand worked with the media agency as well as with sale executives and commercial teams. This is also a clear example of how marketing 3.0 adds value to its consumers and to the company. Quantitatively speaking, this type of actions translates into sales and revenue and they do not just stay as indicators of the brand's top of mind (TOM). The actions of Nestlé with D'Onofrio's Panettone are definitely a total success and an example for other mass consumption companies, showing that the commitment to build a better society contributes more to a brand than developing a productoriented campaign. 



\section{Entel's Launch into the Peruvian Market}

Company's name:

Entel Perú S. A.

Category:

Integrated Communication Services 


\section{migra a entel la señal que estabas esperando raseñal que estabas espera}
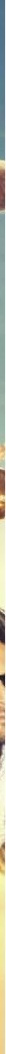

Venimos a escucharte y dejar que te con $m$

con todos por igual, con el servicia $4 G$.
y la mejor experiencia \#LaSeñalQueEsperabas WWW.entel 


\section{A Customer-Focused Strategy in a Highly- Concentrated Market}

When Entel first arrived in Peru, the telecommunications market was mainly focused on two mobile carriers. There were strong barriers to entry for new providers and the supply remained uneventful. The challenge was to enter the market using a disruptive and customerfocused strategy. What did Entel do to make customers spread their wings and migrate?

\section{ENTEL'S History}

Entel's arrival in Peru did not start from scratch. Since 2002, Entel Group has had a presence in Peru through its subsidiary Americatel. Subsequently, having a broader understanding of the market, they acquired Nextel del Peru operations from the American company NII Holdings in 2013. Since then, an important transformation process began: from being focused on the enterprise segment, the company would now be aimed at all segments within the market. Furthermore, it left behind the voice-focused value proposition to go for high-quality data transmission, just like the global market.

\section{BACKground Favorable Winds for Change}

According to official updated figures (June 2013) from the Supervisory Agency for Private Investment in Telecommunications (OSIPTEL), the Peruvian market has a $99.3 \%$ mobile penetration, a coverage of $97 \%$, and a nationwide access to mobile services of $83.1 \%{ }^{1}$.

1 OSIPTEL (2013) Report No. 926-GPR/2013 (https://www.osiptel.gob.pe/Archivos/ ResolucionAltaDireccion/ConsejoDirectivo/Inf-926-GPRC_Res167-CD-2013.pdf) (accessed: July 16). 
Until September 2014, two large carriers shared 95\% of the market ${ }^{2}$. As dictated by theory, this concentration on the supply raised the prices for customers and restrained innovation in the sector, for there was no dynamic competition capable of imposing changes.

For years, these two large carriers developed strong barriers to entry for new entrants. The main obstacle was the existence of private mobile networks, which allowed customers to make phone calls with considerably lower on-net rates.

Although these networks meant-and still do-an economic benefit for users, on the Disaster Check $^{3}$ carried out by Entel before its launch, it was shown that a significant group of Peruvians felt mistrust due to the lack of transparency and credibility in many sectors such as telecommunications. As customers, they felt limited, recipients of bad service, and mistreated.

Amidst this context, fresh air started blowing in favor of the competition. OSIPTEL was in the process of implementing a series of reforms oriented towards enabling the entry of new carriers and providing users with the opportunity to switch carriers freely in case they felt unsatisfied with the service. This could also allow them to switch carriers and keep the same number, which for many customers is an asset within their business or professional development.

The first reform was the amendment on the portability policy, implemented on July 16, 2014, which reduced the process for users to keep their numbers when switching carriers to 24 hours. According to Mediatelecom, Entel is still the carrier with more benefits from numeric portability in Peru. According to official figures from OSIPTEL, Entel showed a positive net balance of 242,828 lines, which makes them the only carrier that showed a positive balance since the program started in July 2014.

2 OSIPTEL (2014) Boletín Osiptel.com volume 01 number 6. December 2014 (http://www.osiptel.gob.pe/ Archivos/Publicaciones/BoletinOSIPTEL_E6/boletinosiptel_e6.html\#1) (accessed: July 16).

3 Research carried out before introducing a new brand into the market, which analyzes the audience's feelings and perceptions regarding a sector, service, brand, etc. 
In November 2014, as a complementary measure to the 24-hour portability, a law requiring the sale of unlocked phones as of January 2, 2015 users are now the actual owners of both the phone number and the device and they have the faculty and freedom to choose the carrier they believe provides the best service. This makes carriers more aware of the effort they need to put in to provide a good service instead of setting barriers to change.

\section{THE STRATEGY}

In this context, Entel developed a launch strategy by introducing themselves as a customer-focused telecommunications carrier that provides a distinctive worldclass experience to individuals and enterprises. All of this is supported by channels, networks, and a culture of service.

The strategy needed to be creative and innovative but, at the same time, consistent with the customer's experience after acquiring the service. After going through the most significant variables for the «adoption» of a new service, it also needed to respond to convenience, network efficiency, and quality of service. All of this also required a direct, real, challenging, honest, yet impressive approach.

Therefore, the launch of Entel—formerly Nextel—needed the international standards of a world-class carrier, for it was necessary to double the telecommunications infrastructure (antennas) to ensure high-quality communication for users, as well as the presence of points of sale and customer service centers while enhancing the product catalog with the latest devices from the world's most important manufacturers. In addition to that, Nextel del Peru's best practices were selected and enhanced. And this was just the beginning.

The brand was introduced under the slogan: «the signal you were waiting for» and the promise to listen to customers to provide them with the service they deserved. Their purpose was to become the only carrier that would break the statu quo of the telecoms market. Thus, they combined slogan, promise and purpose in a disruptive offer which was more convenient than their competitors' (in terms of plans and devices), with all-destination minutes (seeking to break private networks), and highquality $4 \mathrm{G}$ data packages.

4 Presidency of the Council of Ministers (2014). Resolución de Consejo Directivo № 138-2014-CD/OSIPTEL (https://www.osiptel.gob.pe/Archivos/ResolucionAltaDireccion/ConsejoDirectivo/Res138-2014-CD.pdf) (accessed: July 16, 2015). 


\section{The LaUnCh Campaign}

On the creative side, Entel went on for an impressive campaign that encouraged Peruvian customers to try their new added-value proposition using a comparison with human nature: our instinct to migrate-to something better-, making the verb «to migrate» their own, and thus rounding the invitation to: «migrate to Entel.»

This launch campaign was comprised of the following specific campaigns and platforms:

\section{Launch Campaign of the National Brand}

- Presentation of the company and its purpose (A better connection for Peru on the country's most modern network)

- A highly disruptive and global offer for postpaid customers (rate/device)

- A disruptive offer for enterprises

\section{Platforms}

- Prepaid promotions

- Postpaid plans

- Launch of (Smart) terminals

- Launch of (GSM) terminals

\section{Christmas Campaign}

To implement these campaigns and platforms, the most relevant contact points were the mass media (on/off), seeking an adequate balance on TV, written press, and the streets; POS (on/off), based on disruptive supply exhibition through ads and posters; brand activation (off), which involved several branding activations in different locations of Lima and provinces; events (off), with a customer event with the Argentinean Fuerza Bruta show, which was very impressive; and finally, internal communication (on/off) through a teaser campaign, which revealed itself while the brand image renovated internally, seeking not only the organizations talent's commitment, but also their capacity to identify fully with the new scenario.

On the campaign TRP distribution, which measures rating points achieved among targeted individuals within a larger population, the results obtained were higher than 
expected. Upon the launch, the TRP obtained was as follows: 3,500 in Image, 2,700 in postpaid offer (rate+device), 2,700 in postpaid voice destinations, 1,100 in equipment launch, and 3,100 at Christmas.

The audiovisual and graphics were an important part of the strategy. Some examples are presented below:

\section{Image 1. Print Ads}

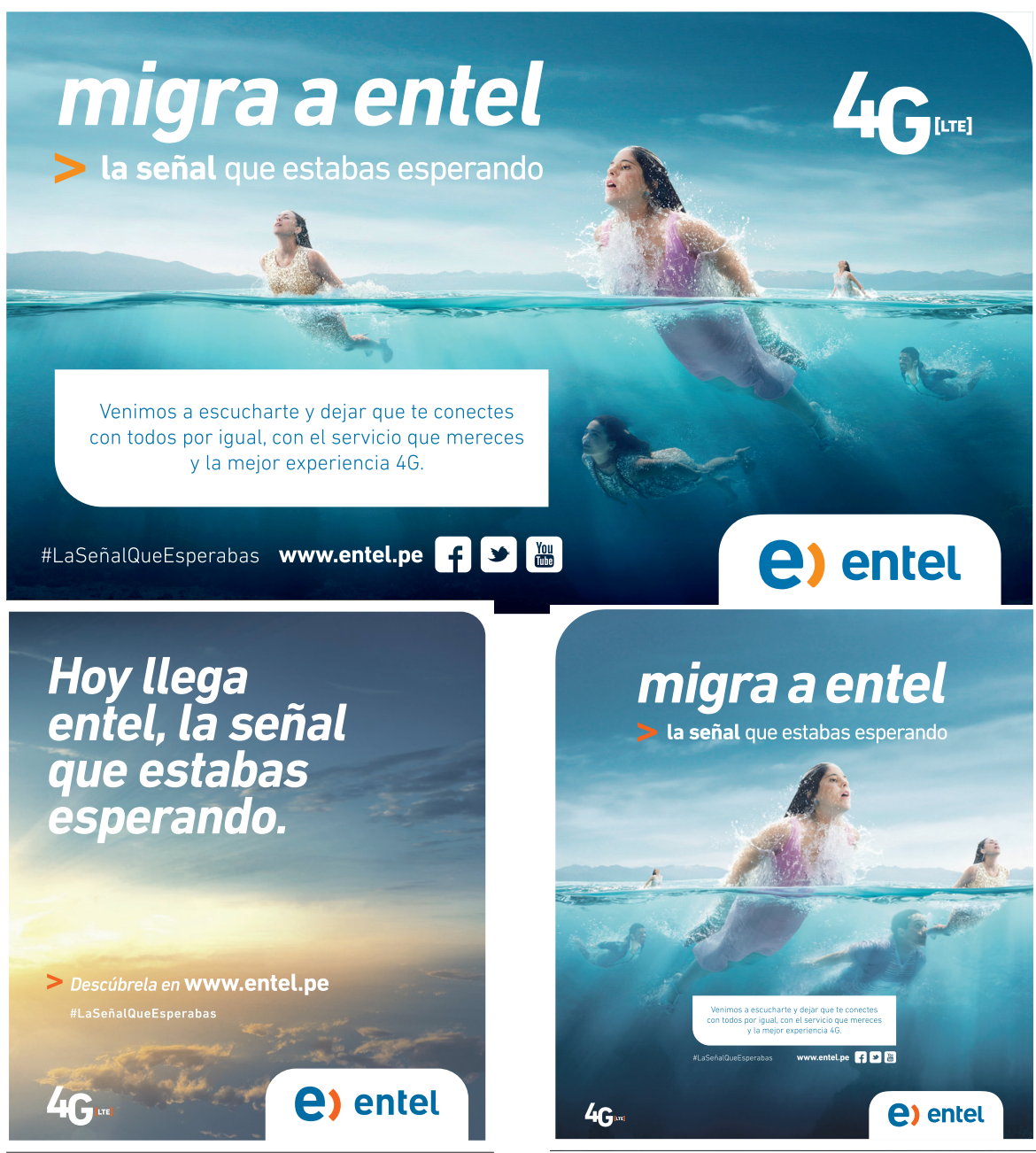




\section{Image 2. Teaser Campaign}
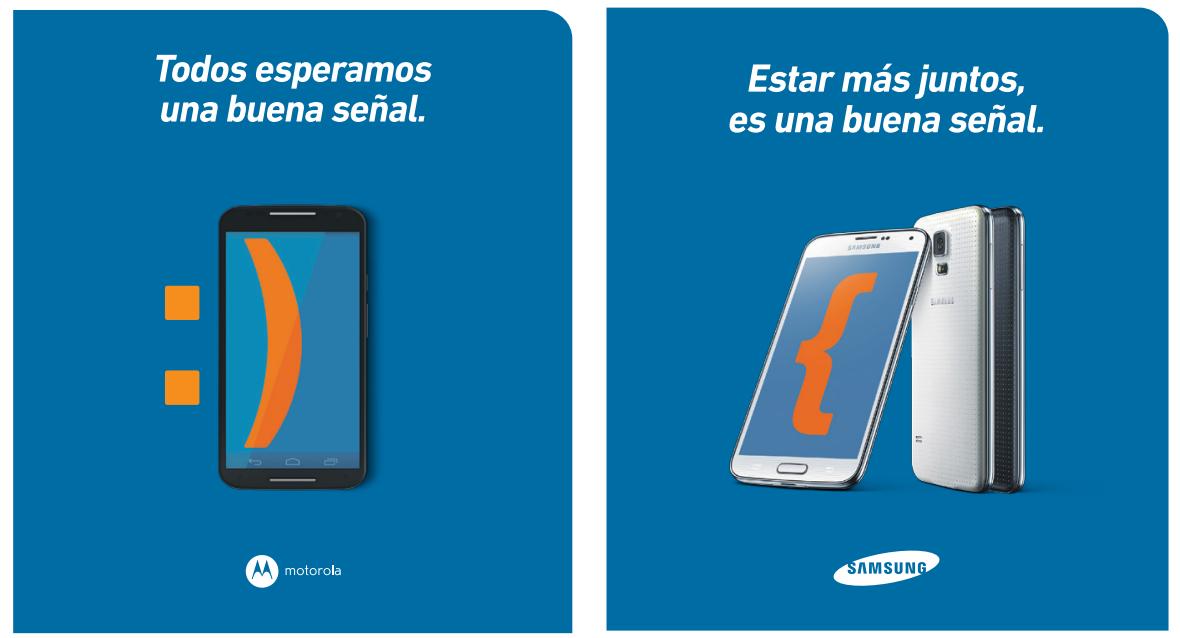

\section{Image 3. Benefits of Migrating}

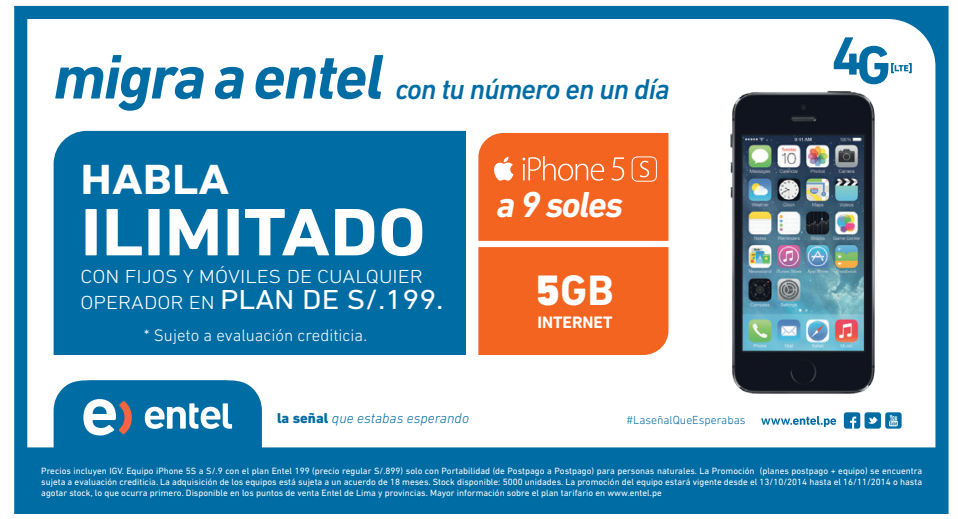

\section{migra a entel \\ CON TU NÚMERO EN UN DÍA Y LLÉVATE UN đ́ iPhone $4 \mathrm{~S}$}
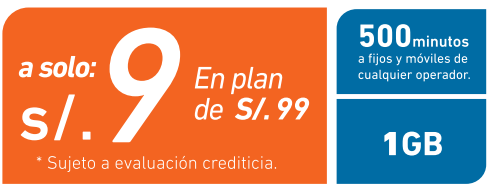

www.entel.pe ff \#LaSeñalQueEsperabas

la señal que estabas esperando

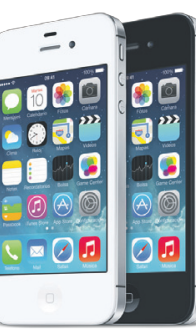

e) entel 


\section{Image 4. Digital Ads (Google Display)}
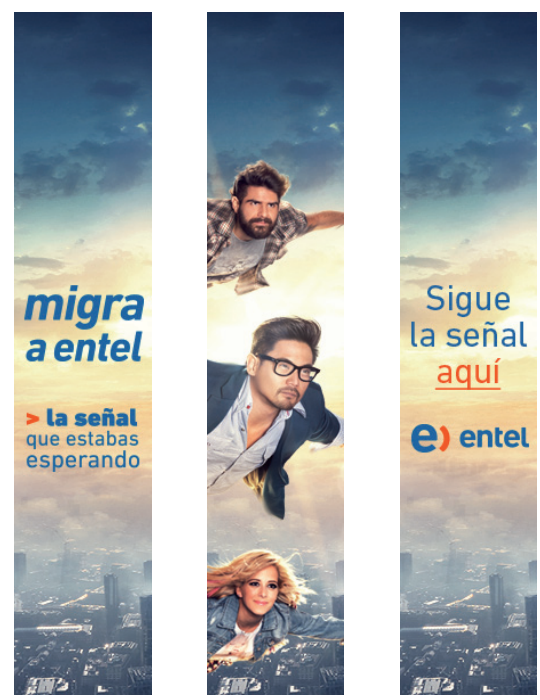

\section{CAMPAign Results: A GOOD START FOR ENTEL}

As a result of the launch strategy, Entel's sales increased by $350 \%$ over the figures obtained when it was NEXTEL, during the launch quarter (IVQ 2014) vs. the same period of the previous year (IVQ 2013). At first, the sales were expected to double from the 2013 quarter to 2014, but they finally tripled.

This was possible thanks to users being able to «migrate to the signal they had been waiting for.» Entel Peru increased their customer base by 257,964 customers in just three months, with a high percentage of high-value customers. Thus, by the end of 2014, Entel had a customer base of 1,738,450 users, $67.5 \%{ }^{5}$ of which were postpaid customers with data plans.

Consequently, the telecommunications market share distribution began to change. Only Entel and Bitel won portability customers by the end of 2014, from which Entel was the leader carrier with 87,078 customers switching to the company. This amount accounts for $52.2 \%$ of the total portability cases ${ }^{6}$.

In the fourth quarter of 2014, Entel Peru captured 39\% of net growth among

$5 \quad$ Bitel is not considered.

6 Osiptel.com (2015) Osiptel Bulletin. No. 7. March (http://www.osiptel.gob.pe/Archivos/Publicaciones/ BoletinOSIPTEL_E7/boletinosiptel_e7.html\#4) (accessed: September 15) 
postpaid customers and 33\% among prepaid customers. By December 2014, less than three months after launching, a $1 \%$ increase in postpaid market share was achieved. In other words, the market share went from $8.3 \%$ to $9.3 \%$.

The launch strategy also started to reap what it sowed in terms of positioning. According to Arellano Marketing, after two months of launching, Entel, a completely new brand in the market, reached a brand awareness ${ }^{7}$ of $53 \%$, as well as a brand top of mind (TOM) of 5.2\% when respondents were asked about «the mobile phone brand you remember.» The survey considered the A B target segments from Lima, Piura and Arequipa

In this sector, the ideal brand TOM, built throughout time, must be similar to the market share. Being a brand with little more than two months on the market and achieving a 5.2\% TOM with a share of 9.3\%, Entel largely exceeds this ideal.

During the same period, Entel achieved an advertising TOM of $33.6 \%$ when respondents were asked about «the mobile phone ad you remember,» which is a very encouraging result considering that the launching and Christmas campaigns lasted only two months.

The Arellano Marketing research study also revealed that Entel's brand perception, compared to the competition's, was considered as the youngest, most professional, technological, engaging, successful, friendly, trustworthy, hard-working, fun, among other personality adjectives.

Similarly, it is also important to discuss the free impact obtained in the media. After its launch between October and December 2014, Entel managed to publish free articles and notes, also known as publicity, in the communication media most relevant for their target audience. These impacts are worth USD 194,915 ; that is, USD 60,000 above the second carrier with the best results.

During the same period, the news was mainly positive (based on reviews), since no negative news was registered.

7 In other words, Entel is on people's minds as a mobile carrier option.

8 Report carried out by Agencia de Monitoreo Noticias Perú, upon request of Entel Perú. The agency does not deal with public relations management. This rating has a standard methodology in monitoring news while considering advertising costs assigned to the spaces occupied by the news, at a cold rate. 


\section{CAMPAign ReSUlts: A GOOd START FOR USERS}

From communication to experience, Entel has now become a brand whose users (customers who acquired their services) consider it a carrier with good quality and affordable plans, rates, and phones in terms of communication, customer service, and information transparency. Furthermore, they feel identified with the company. All of the aspects identified on the Arellano Marketing research study are shown on the following charts.

\section{Figure 1. Attribute Association: Entel Carrier}

People whose main operator is Entel associate it with the most attributes, among them: modern equipment, company with which I identify, and varied promotions. On the other hand, Movistar is associated with coverage and experience and Claro with experience, but to a lesser extent than Movistar.

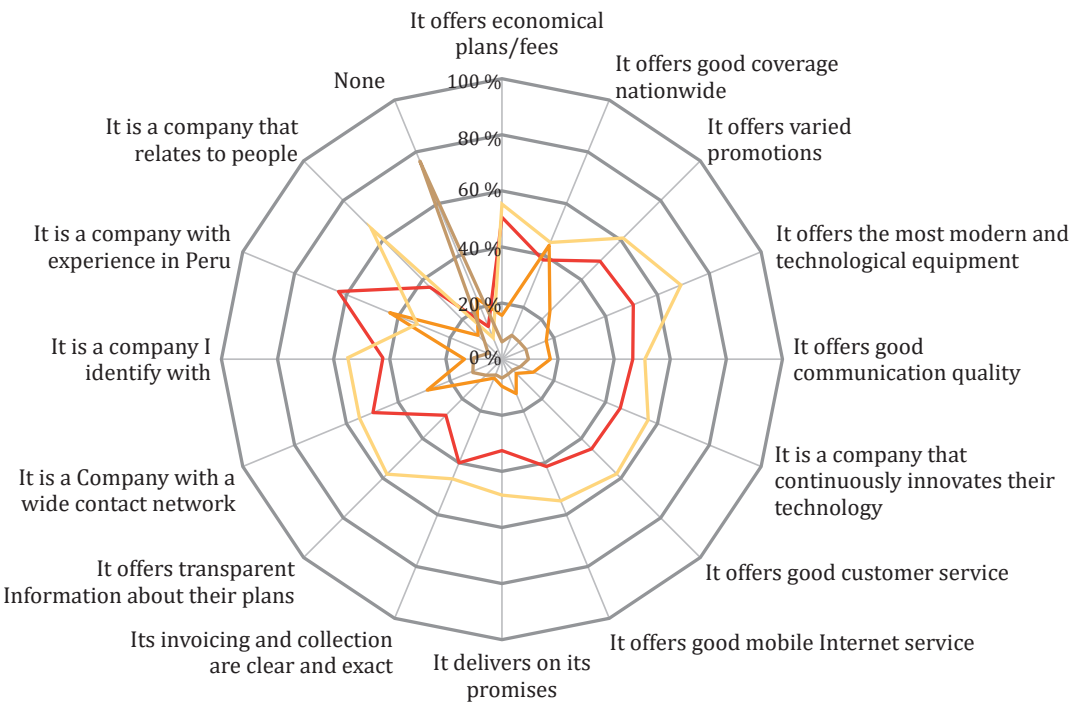

Base: 151

\section{Claro Entel Movistar Nextel}

*The total most valued attributes of the Image and Positioning study have been identified

${ }^{* *}$ ) Tuenti and Bitel do not belong in the chart because they are not associated to any attribute in a proportion larger than $90 \%$ for both cases 


\section{Figure 2. Brand Personality: Entel Carrier}

$100 \% \quad 80 \% \quad 60 \% \quad 40 \% \quad 20 \% \quad 0 \% \quad 20 \% \quad 40 \% \quad 60 \% \quad 80 \% \quad 100 \%$

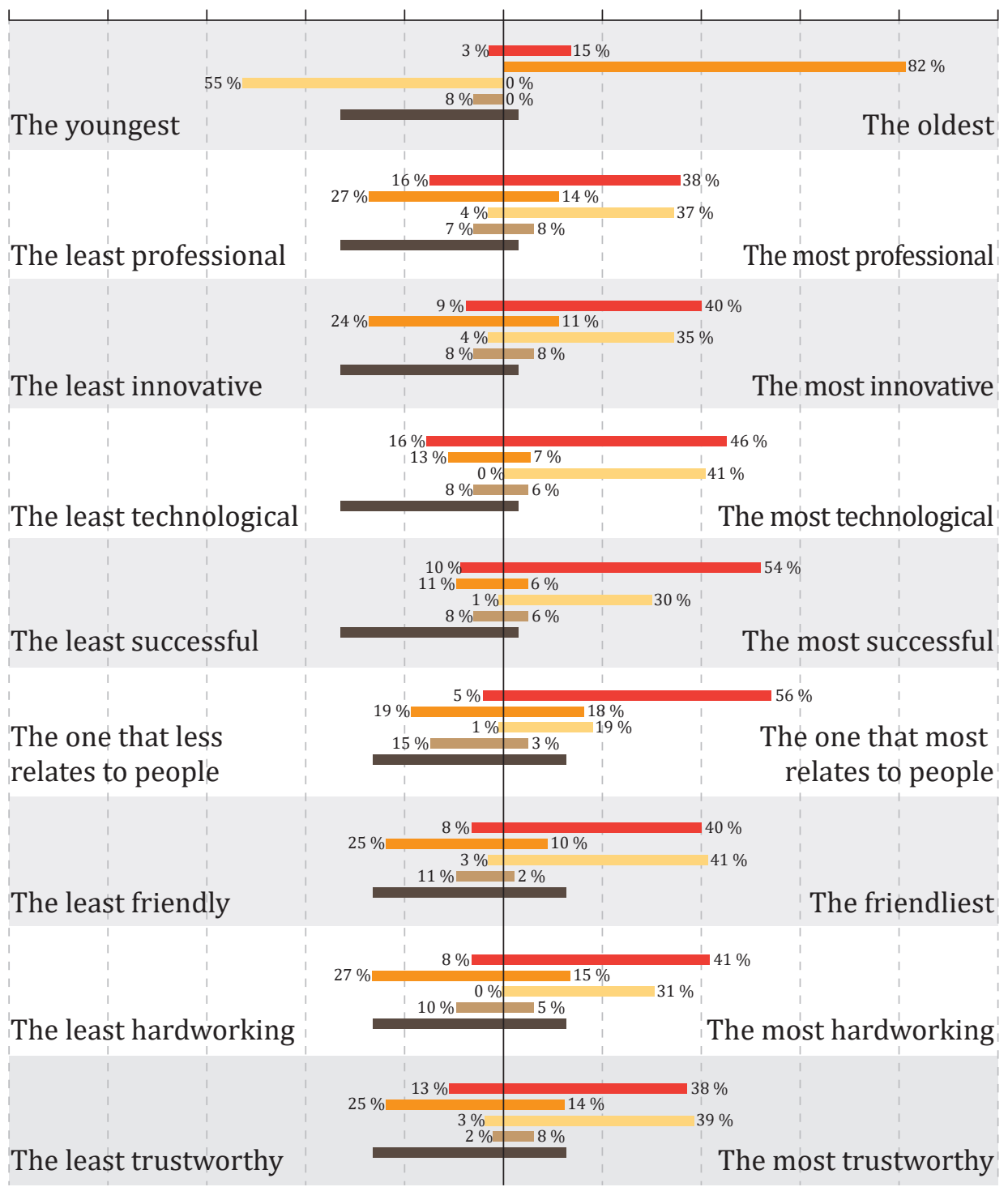




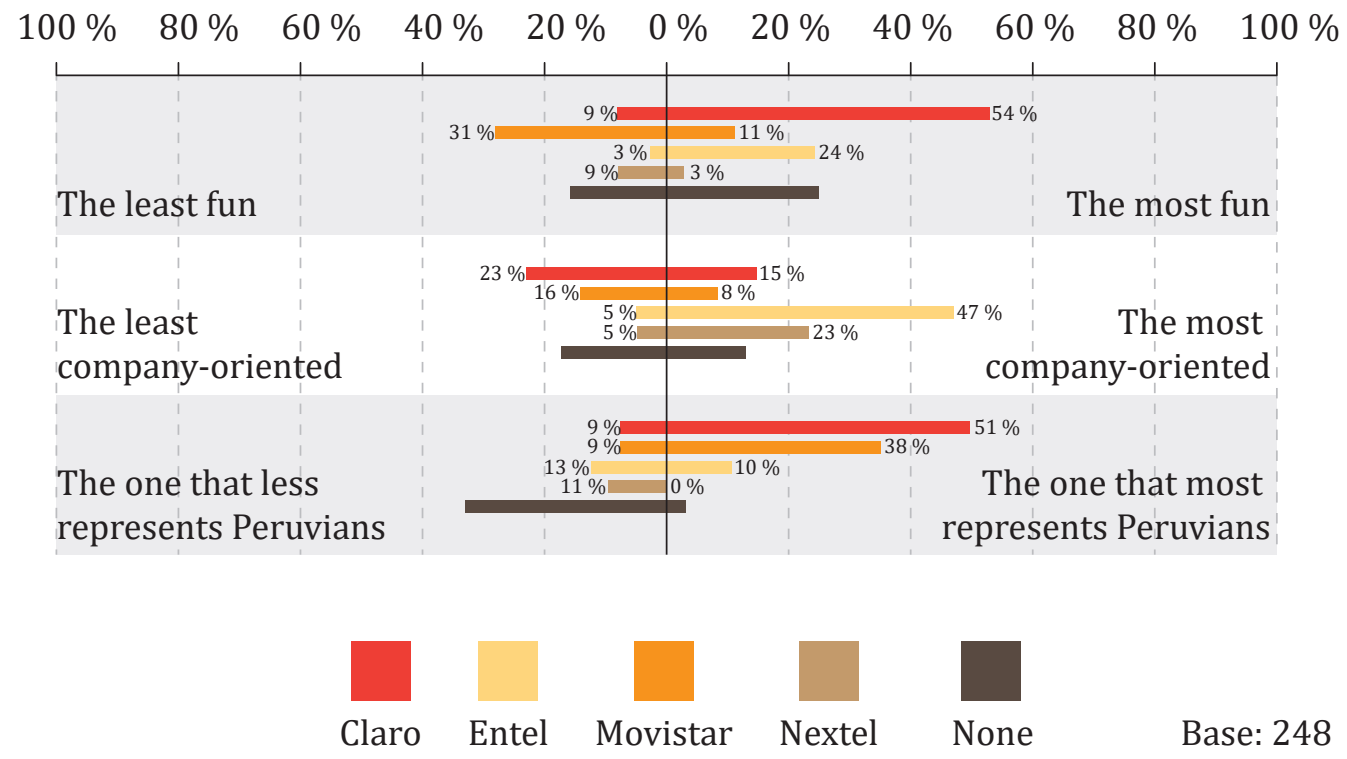

Source: Arellano Marketing 2015

In a study by $\mathrm{GFK}^{9}$, Entel Peru had $61 \%$ satisfaction indicators in the same short post-launch period, which clearly surpassed the competition's (ten points above the second carrier with the best satisfaction level). The most important aspects regarding satisfaction were data signal quality, service quality, and transparency.

Regarding data signal quality, Entel had $61 \%$ satisfaction $(23$ points above the closest competitor). Service quality had similar results; Entel had $60 \%$ satisfaction (20 points clear of the competition).

Similarly, regarding transparency perceived by customers, Entel had $61 \%$ satisfaction (12 points clear of the closest competitor).

According to OSIPTEL, the telecommunications sector was consolidated as one of the economy's driving forces thanks to the introduction of new carriers such as Entel and Bitel by growing $8.42 \%$ in $2014^{10}$. The introduction of new carriers also invigorated the market: the competition meant that old carriers needed to provide

9 GFK (December 2014) Multibrand Research carried out on men and women over the age of 15 who had an active cellphone line.

10 Osiptel.com (2015) Osiptel Bulletin. No. 7. March (http://www.osiptel.gob.pe/Archivos/Publicaciones/ BoletinOSIPTEL_E7/boletinosiptel_e7.html\#4) (accessed: September 15) 
promotions and benefits to keep their customers.

It is also worth saying that Entel was the only carrier that supported the legislations proposed by OSIPTEL, such as 24-hour portability (supported by former Nextel), the sale of unlocked phones (which was effective as of January 2015), and the reduction of mobile interconnection charges (which will break private networks and allow users to make phone calls to all destinations without increasing their bills).

The arrival of Entel also enabled OSIPTEL (the regulating authority) to register record portability numbers, which increased by $558 \%$ between September and October, as chart 3 shows. Entel's impact on this indicator was decisive.

Figure 3. Mobile Portability as of February 2014

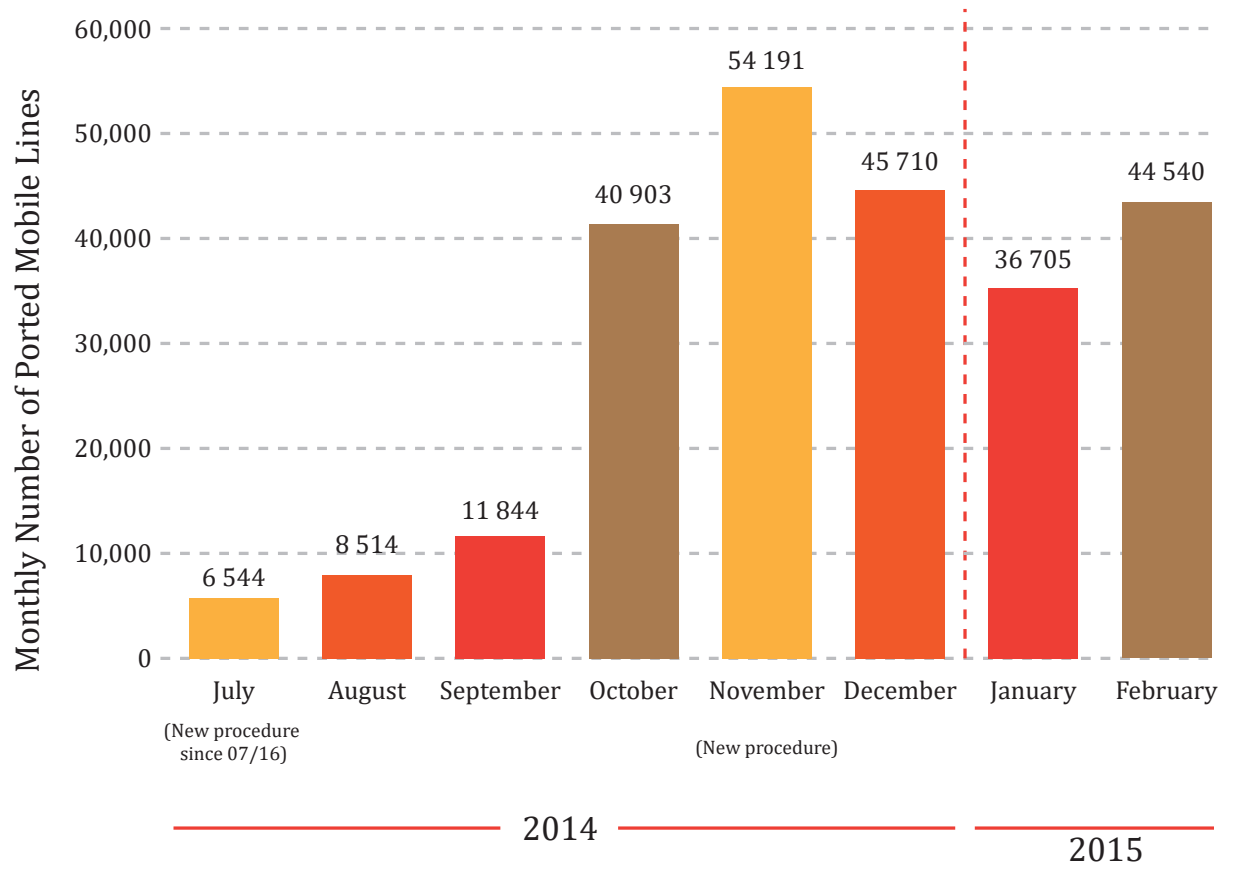

Source: OSIPTEL (2015) (http://www.osiptel.gob.pe/noticia/osiptel-portabilidad-movil-incremento-21-febrero) (accessed: July 16). 
In sum, it can be said that Entel, in a few months and accompanied by a disruptive, transparent and all-destination minutes offer, reached a portability record in Peru's history of mobile telephony, and registered a significant increase in the frequency of promotions launched by existing carriers, as well as an offer of high-end terminal phones, in favor of users. In a two-carrier-focused market, there was little users could do. Entel's introduction, its commitment to the law, and its communication campaign have enabled customers to choose the best company to meet their needs.

\section{Opinion}

Will Entel be able to capture the 7\% of market share or its equivalent of 2.5 million subscribers in 2015? What do they need to keep growing at a rate of 220,000 customers quarterly? How can they successfully face an uncertain political, social and economic scenario? On one hand, they can keep focusing on an aggressive price war on the prepaid business (PEN 0.20 rates), against the giants Claro and Movistar. A second alternative might be to increase the ARPU (average revenue per user) through a $3 \mathrm{G}$ to $4 \mathrm{G}$ upgrade program for customers by making the most of their high-end phones and data packages. What would the best strategy be for provinces? The development of Information and Communication Technologies (ICTs) contributes decisively to competitiveness, which is understood as the improvement of social welfare, by increasing the capacity for innovation and productive efficiency of people and businesses, regardless of size or resources. In Peru, when we aspire to have a knowledge-based, more competitive, dynamic and productive economy with better job opportunities, the access to ITCs becomes a revitalizing driving force, hand in hand with fair competition among carriers, which is regulated by an efficient authority. Marketing will allow the delivery of better value propositions to customer segments, and the market will determine the success or failure of those. We must always consider this industry's multiplying effect when analyzing this case.

Jack Zilberman

Dean of the School of Business at UPC 



\section{UPC University Press Recent Publications}

2015

Salas Arriarán, Sergio

Todo sobre sistemas embebidos. Arquitectura, programación y diseño de aplicaciones prácticas con el PIC18F

Lossio Chávez, Felix and Vargas Negrete, María del Carmen

Sueños de oriente. Consumo de cine de la India y telenovelas coreanas en el Perú

Carrera de Diseño y Gestión en Moda

Técnicas de patronaje Tomo II - Hombre

Arnáez Braschi, Enrique

Enfoque práctico de la teoría de robots. Con aplicaciones en Matlab

Herz Ghersi, Jeannette

Apuntes de Contabilidad financiera. Segunda edición

Aguirre, Mauricio; Maldonado, Claudia; Peña, Cinthia, and Rider, Carlos (comps). Cómo leer y escribir en la universidad. Prácticas letradas exitosas. Segunda edición

Aguirre, Mauricio; Maldonado, Claudia; Peña, Cinthia, and Rider, Carlos (comps). Cómo leer y escribir en la universidad. Cuaderno de trabajo. Segunda edición

2014

Olins, Wally

Brand New. La esencia de las futuras marcas

Velásquez Aguilar, Luis Oscar

Niños hospitalizados. Guía de intervención psicológica en pacientes infantiles

Peña Larrea, Cinthia (comp)

Más allá de las palabras. Una propuesta de análisis crítico del discurso

Soria Aguilar, Alfredo F. and Osterling Letts, Madeleine

Contratos modernos. Elementos esenciales y reglas aplicables para acuerdos comerciales 
Rodríguez Félix, César y Mauricio Alza, Saby

Nutrición oncológica. Guía de alimentación para vivir mejor

Chu Rubio, Manuel and Agüero Olivos, Carlos

Matemática para las decisiones financieras

Romero Tapia, José Fernando

Integrando mercados. MILA, motor de la Alianza del Futuro

Arrascue Córdova, Lily

Física mecánica. Nivelación para estudiantes universitarios

Arnáez Braschi, Enrique

Enfoque práctico del control moderno. Con aplicaciones en Matlab

Sardón Taboada, José Luis (editor)

Revista de Economía y Derecho

Verano de 2014, vol. 11, nro. 41

Valdivia Pareja, Álvaro

Suicidología. Prevención, tratamiento psicológico e investigación de procesos suicidas

Egoavil Vera, Juan Raúl

Fundamentos de matemática. Introducción al nivel universitario

Chu Rubio, Manuel

Finanzas para no financieros. Cuarta edición

Parodi Revoredo, Daniel

Conflicto y reconciliación. El litigio del Perú contra Chile en la Corte de La Haya (2008-2014)

Aguirre, Mauricio; Maldonado, Claudia; Peña, Cinthia, and Rider, Carlos (comps). Cómo leer y escribir en la universidad. Prácticas letradas exitosas.

Aguirre, Mauricio; Maldonado, Claudia; Peña, Cinthia, and Rider, Carlos (comps). Cómo leer y escribir en la universidad. Cuaderno de trabajo.

For more publications by UPC University Press in both digital and written versions, please visit: www.upc.edu.pe/editorial

Please visit UPC University Press Facebook Page: www.facebook.com/editorialupc 





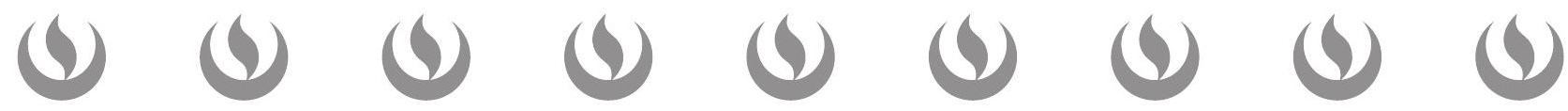

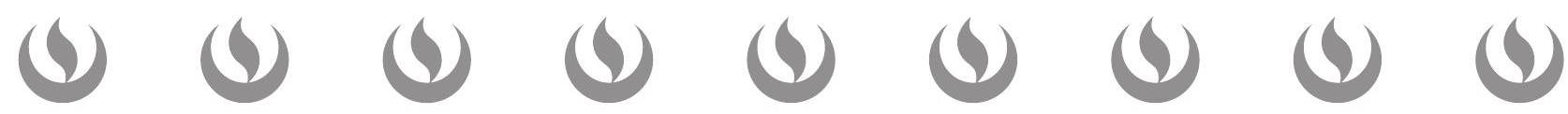

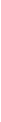

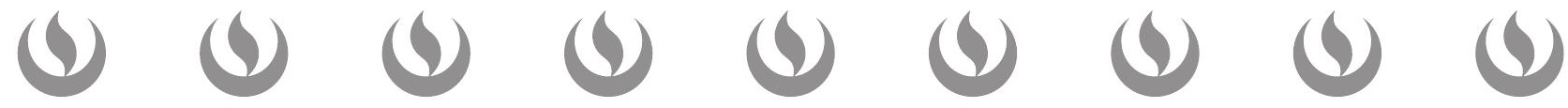

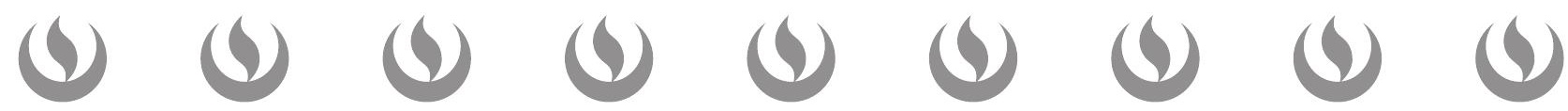

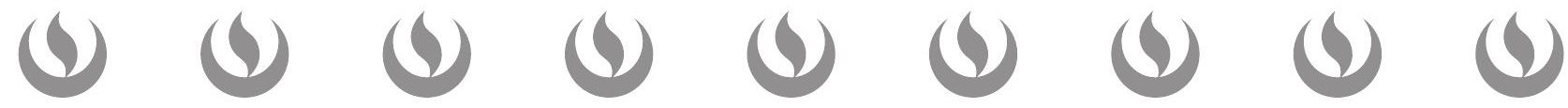

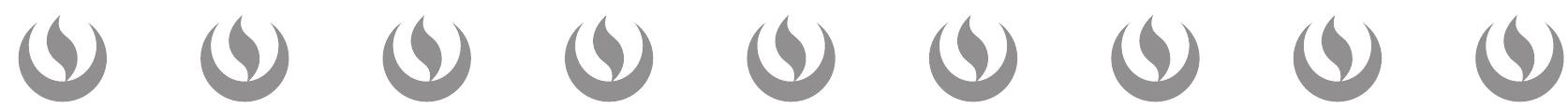

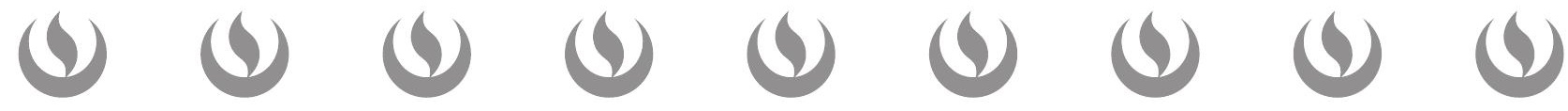

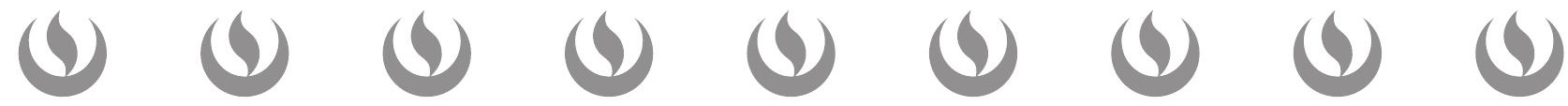

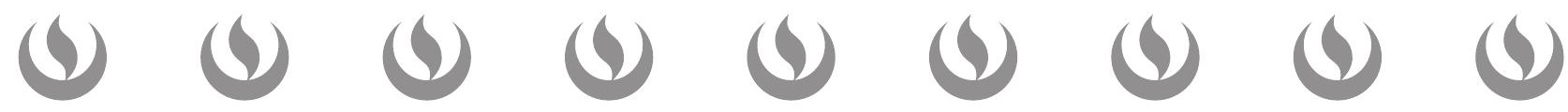

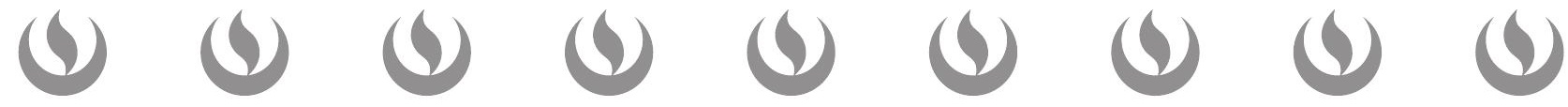

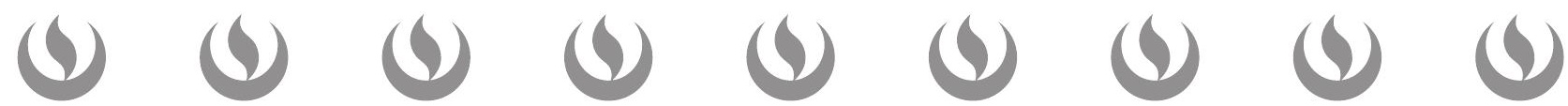

